\title{
Core and Geophysical Analysis of Biogenic Tufa Deposits in the Spring River in Northern Arkansas
}

Tyler W. Engelbart

Missouri State University, Engelbart18@live.missouristate.edu

As with any intellectual project, the content and views expressed in this thesis may be considered objectionable by some readers. However, this student-scholar's work has been judged to have academic value by the student's thesis committee members trained in the discipline. The content and views expressed in this thesis are those of the student-scholar and are not endorsed by Missouri State University, its Graduate College, or its employees.

\section{Follow this and additional works at: https://bearworks.missouristate.edu/theses}

Part of the Geology Commons, Geophysics and Seismology Commons, and the Hydrology

\section{Commons}

\section{Recommended Citation}

Engelbart, Tyler W., "Core and Geophysical Analysis of Biogenic Tufa Deposits in the Spring River in Northern Arkansas" (2020). MSU Graduate Theses. 3500.

https://bearworks.missouristate.edu/theses/3500

This article or document was made available through BearWorks, the institutional repository of Missouri State University. The work contained in it may be protected by copyright and require permission of the copyright holder for reuse or redistribution.

For more information, please contact BearWorks@library.missouristate.edu. 
CORE AND GEOPHYSICAL ANALYSIS OF BIOGENIC TUFA DEPOSITS IN

THE SPRING RIVER IN NORTHERN ARKANSAS

\author{
A Master's Thesis \\ Presented to \\ The Graduate College of \\ Missouri State University \\ In Partial Fulfillment \\ Of the Requirements for the Degree \\ Master of Science, Geospatial Sciences
}

By

Tyler Wes Engelbart

May 2020 
Copyright 2020 by Tyler Wes Engelbart 


\title{
CORE AND GEOPHYSICAL ANALYSIS OF BIOGENIC TUFA DEPOSITS IN THE
}

\section{SPRING RIVER IN NORTHERN ARKANSAS}

Geography, Geology, and Planning

Missouri State University, May 2020

Master of Science

Tyler Wes Engelbart

\begin{abstract}
The Spring River is fed by Mammoth Spring, a large spring on the Missouri-Arkansas border which produces roughly 240 million gallons of water per day (MGD). In this area there are deposits that appear as dams which cause water to pool upstream. Aerial analysis of the dams shows that there are approximately 100 of these features present in the first 45 miles downstream of Mammoth Spring. These deposits, known as tufa, are not uncommon in a karstic area of a spring fed river, but these are more frequent farther downriver than near the mouth of the spring. Preliminary mapping data shows structural features in this region of Arkansas. Geophysical studies using resistivity and VLF were conducted in meander bends to determine if tufa deposits underlie the former river channels. The geophysical data suggests joints/fractures under the riverbanks that go toward the river and near the tufa. Imagery study of the deposits using Google Earth and ArcGIS show the dams to have similar orientations in both N to S and NE to SW trend, which suggests structural control. Eight core samples were taken from three different dam locations to understand the vertical extent of the deposits. The core holes range in depth from two feet to nine feet. Detailed core logs, calculated surface porosity, core hole depth, and GPS location were created for each core sample taken. Thin sections were made from several core samples and show a biogenic/stromatolitic growth pattern with secondary crystal growth. SEM analysis showed the growth of filaments in the pore spaces on each sample of the tufa.
\end{abstract}

KEYWORDS: Spring River, Arkansas, tufa, core analysis, geophysics, and biogenic. 


\title{
CORE AND GEOPHYSICAL ANALYSIS OF BIOGENIC TUFA DEPOSITS IN THE SPRING RIVER IN NORTHERN ARKANSAS
}

\author{
By \\ Tyler Wes Engelbart \\ A Master's Thesis \\ Submitted to the Graduate College \\ Of Missouri State University \\ In Partial Fulfillment of the Requirements \\ For the Degree of Master of Science, Geospatial Sciences
}

May 2020

Approved:

Douglas R. Gouzie, Ph.D., Thesis Committee Chair

Charles W. Rovey II, Ph.D., Committee Member

Kevin L. Mickus, Ph.D., Committee Member

Julie Masterson, Ph.D., Dean of the Graduate College

In the interest of academic freedom and the principle of free speech, approval of this thesis indicates the format is acceptable and meets the academic criteria for the discipline as determined by the faculty that constitute the thesis committee. The content and views expressed in this thesis are those of the student-scholar and are not endorsed by Missouri State University, its Graduate College, or its employees. 


\section{ACKNOWLEDGEMENTS}

I want to thank all the department members in the Geology, Geography, and Planning for giving me guidance, support, and necessary resources. Thank you to Denna Gibson for always being around to give a lending hand and talk to me about other things then just school. When I had a problem or needed something you were always there to the rescues.

Thank you to Dr. Douglas Gouzie for the opportunity and support you provided and the help when needed. Even though you disliked when I would just pop into your office without an email or scheduled time. Thank you to Dr. Kevin Mickus for allowing me to use your geophysical equipment and for helping with field work. Thank you to Dr. Charles Rovey II for helping with the core samples, teaching me how to make thin section, and help with the field work when coring. Thank you to Dr. Toby Dogwiler for allowing me into your lab to use your camera to take 100's of photos and for the guidance on the editing portion of them also.

I would like to thank the Missouri State Survey for allowing me to use their equipment and tools. I would like to thank the Arkansas State Survey for helping me out in the field during the coring process, giving me input, and sharing their mapping data with me to use in my thesis. I would also like to thank Bennett Conway, Jordan Vega, Jordan Cruzan, and Charles Hoffman for the time they gave up to helping me in the field.

Lastly, I would like to thank all my family and friends for the support given. I would like to thank Emily, Kristin, Candida, Dillion, and my Mom for helping with edits throughout the writing process and the support they gave. I would also like to thank Dr. James Ward and my dad for giving me guidance in some hard times and helping me to push through and finish what I started. 


\section{TABLE OF CONTENTS}

Introduction

Karst Areas

Tufa and Travertine Deposits

Water Chemistry

Temperature Influences

Geological Structure Influences

Study Area

Climate

Methods

Aerial Data Analysis $\quad 8$

Geophysical Surveys $\quad 9$

Coring 12

Core Photograph Analyses 15

$\begin{array}{ll}\text { Thin Section and SEM } & 19\end{array}$

Results $\quad 21$

Imagery Analysis $\quad 21$

Geophysics $\quad 22$

$\begin{array}{ll}\text { Coring } & 34\end{array}$

Thin Section and SEM Data 37

Discussion $\quad 39$

Structure Analysis $\quad 39$

Geophysical Analysis $\quad 41$

Core Analysis $\quad 44$

Microscopic Analysis $\quad 47$

General Discussion $\quad 52$

$\begin{array}{ll}\text { Conclusion } & 54\end{array}$

Future Research $\quad 55$

References Cited

$\begin{array}{ll}\text { Appendices } & 60\end{array}$

Appendix A. Aerial Imagery Analysis Table $\quad 60$

Appendix B. Flyer that was handed out 63

Appendix C. Core Log table $\quad 64$

$\begin{array}{ll}\text { Appendix D. Core box photos } & 75\end{array}$ 


\section{LIST OF TABLES}

Table 1. The core hole depth versus core recovery for RR, SS, and CJ. 


\section{LIST OF FIGURES}

Figure 1. Satellite image of the study area in northern Arkansas 6

Figure 2. Satellite image of the study area for geophysics 10

Figure 3. Satellite image of the study area for coring 13

Figure 4. General surface texture of the tufa and how the measuring 15

stick was used to note the core hole depth

Figure 5. Pencil marks on the sample holder 16

Figure 6. Detailed process on the tools used to clear out the 17

$\begin{array}{ll}\text { Figure 7. Tools used to convert an image } & 17\end{array}$

Figure 8. Steps used to perform an auto threshold 18

Figure 9. Rose diagram created from the general trends 21

Figure 10. Satellite image showing the location of the first geophysical 24

site just outside of Mammoth Spring.

Figure 11. The collected geophysical data from survey line Jen-a 25

Figure 12. The collected geophysical data from survey line Jen-b 26

Figure 13. Satellite image showing the location of second geophysical 27

site at Riverside Resort Camp and Canoe

Figure 14. The collected geophysical data from survey line RR-a 28

Figure 15. The collected geophysical data from survey line RR-b 29

Figure 16. Satellite image showing the location of the third 30

geophysical site at Circle J Farms

Figure 17. The collected geophysical data from survey line CJ-a 31

Figure 18. The collected geophysical data from survey line CJ-b 32

Figure 19. Color image of the IP data produced by the VLF-EM 33

Figure 20. Core that was collected from Riverside Resort Camp and 36

Canoe

Figure 21. Thin Sections made from Core RR1 37

Figure 22. SEM image from Core, RR $1 \quad 38$

Figure 23. SEM image from Core RR 2

Figure 24. Diagram on the right are joints trends in southern Missouri 39

Figure 25. Diagram to the left is the general trend of the tufa 40

Figure 26. Interpreted geophysical model of survey Jen-b 42

Figure 27. Interpreted geophysical model of survey RR-a 42

Figure 28. Interperted geophysical model of survey CJ-a 43

Figure 29. Schematic cross-section 45

Figure 30. Schematic of the coring location at Circle J Farms 46

Figure 31. Thin section in cross polar light 48

Figure 32. SEM image from Rainey and Jones 48

Figure 33. Core sample from RR in the second core hole $\quad 50$

Figure 34. Tufa deposit exhibiting undercutting 51 


\section{INTRODUCTION}

\section{Karst Areas}

The term karst is given to a region of land dominated by unique surface and subsurface features resulting from soluble bedrock (White, 2002). Some subsurface features in a karst area are solutionally widened fractures and bedding plane(s), which can become a conduit of flow. A conduit of flow develops when water infiltrates along a crack, joint, fault, or a bedding plane in a rock formation (Evans, 1999). These structures help increase the permeability of the rock, which aids in the movement of water through the subsurface and can therefore have zones of increased karst formation (White, 2002).

Infiltrating water dissolves rocks along fractures which widen through dissolution. For water to dissolve away rock, it needs to be slightly acidic. Rainwater is slightly acidic due to the absorption of carbon dioxide during precipitation and from percolation through soil (White, 2002). The acidic water needs to be able to enter and exit the subsurface to be able to dissolve away the rock. Water in the subsurface enters through surface features like a sinkhole, and exits through features such as springs (White, 2002; Evans, 1999). A spring is a location at the surface where water flowing through a conduit intercepts the surface and allows water to exit from the subsurface (Palmer, 1991). As the temperature of the water increases when rising to the surface, or with aeration as the surface stream flows over a rough bed, it can cause a loss of carbon dioxide, which can lead to supersaturation, and occasional deposition of calcite in the form of a calcareous tufa or travertine (White, 1988). 


\section{Tufa and Travertine Deposits}

Tufa deposits are commonly formed by calcium bicarbonate-rich water, low deposition rates, and display a porous structure and poor bedding (Capezzuoli et al., 2014). In contrast, travertine is more commonly formed at higher rates of deposition, with low porosity, and distinct bedding (Capezzuoli et al., 2014; De Filippis et al., 2012). The terms tufa and travertine are often used indiscriminately as alternative names for classifying the same freshwater carbonate material (Julia et al., 1983; Cappezzouli et al., 2014). Tufa is generally deposited from ambient-temperature water (cool water), whereas travertine is used for warm to hot water hydrothermal deposition (Pedley et al., 1990; Manzo et al., 2011). Tufa deposits have been referred to as continental carbonates, which are predominantly of calcite, these are typical of karstic regions (Ford and Pedley, 1996; Owen et al., 2010)

Types of tufa. Some tufa deposits are characterized by ambient-temperature precipitation from cooled, deeply cycled waters. These deposits differ from normal tufa and are sometimes referred to as travitufa (Capezzuoli et al., 2014). Tufa deposits can also have a micro/macrobiota texture in shallow water systems. Aragonite is absent except in spring waters that have a high $\mathrm{Mg} / \mathrm{Ca}$ ratio (Capezzouli et al., 2014).

Some Canadian carbonate spring deposits in cold (50-70 degrees F) water were formed primarily from moss encrusted with calcium carbonate (Rainey and Jones, 2007). Moss has been recognized as a primary frame builder for tufa deposits for a long time (Rainey and Jones, 2007). In these types of tufa deposits, a series of different patterns can be seen in the structure. Rainey and Jones, (2007) reported four patterns of growths that can be repeated or skipped throughout the life cycle of the tufa development. Manzo et al. (2012) describe tufa as having both macro and microscopic growth features. On the micro scale, they consist of multi-layered laminae that 
exhibit upward growing filaments. The tufa also have stromatolitic texture that is separated into multiple layers with a fan-like structure (Manzo et al., 2012). This is representative of a biogenic process that created the tufa in a cold water setting in the Corvino River Valley.

Another example of tufa deposits is present in the Badlands of South Dakota (Evans, 1999). In this area, tufa deposits are caused by the calcium carbonate-rich groundwater mixing with surface water (Evans, 1999). The mixing of the groundwater occurs when it comes into contact with the surface water through geologic structures in the surrounding rock formations (Evans, 1999).

\section{Water Chemistry}

Karst water that emerges from a spring can contain large amounts of dissolved calcite at high $\mathrm{CO}_{2}$ partial pressures, although many of these waters are only slightly supersaturated (White, 1988). As water flows downstream over a rough bed, a loss of $\mathrm{CO}_{2}$ and supersaturation occur. Then calcite in the form of calcareous tufa or travertine can form (White, 1988). Both tufa and travertine deposits are driven by $\mathrm{CO}_{2}$ degassing (Crossey et al., 2006). As a result, a controlling factor in the growth rate of tufa and travertines is the amount of $\mathrm{CO}_{2}$ degassing from water (Manzo et al., 2011; Kano et al., 2003; Kawai et al., 2006). Crossey et al. (2006) show that in the Grand Canyon, an excess of $\mathrm{CO}_{2}$ was a driving factor in the size of travertine deposits. Manzo et al. (2011) analyzed deposition rates on a microscopic scale. Toran and Roman (2006) show that the change in amount of $\mathrm{CO}_{2}$ in the water directly correlates to the seasons throughout the year. 


\section{Temperature Influences}

The most common factor affecting the temperature of the water is climate (Jacobson and Langmuir, 1974). Jacobson and Langmuir (1974) showed that change in the surrounding ambient air temperature affects the temperature of the surface water. Evans (1999) states that colder air temperature slows the deposition rate of tufa, while warmer air temperature accelerates the rate of deposition. The change in the air temperature coincides with the change of seasons during the year.

Change in the surface water temperature can occur at different locations down river where groundwater interacts with the stream water (Luhmann et al., 2011; Altunel and Hancock, 1996). Once the mixing of the water at two different temperatures occurs, this allows for $\mathrm{CO}_{2}$ to degas from the water and allows for deposition of tufa at that location (Crossey et al., 2006; Hancock et al., 1999). Water temperature can also change if the river is being fed by a geothermal spring. With this, an increase in tufa deposition will occur due to the sharp contrast of warmer groundwater mixing with colder river water (Brogi et al., 2012).

\section{Geological Structure Influences}

Within the subsurface, water moves through faults, joints or cracks, bedding planes, and other structural features. These features can help to influence the location of tufa and travertine deposits. Brogi et al. (2012) suggest that the location of tufa and travertine deposits could be useful in determining the geometry of the main faults and their related minor structures. Crossey et al. (2006) point out that within the Grand Canyon a series of travertine deposits are concentrated around fault zones that intersect with the Muav Limestone aquifer. In western 
Turkey, many travertine deposits are located along faults and fractures found in quarries (De Filippis et al., 2012).

\section{Study Area}

The study area for this thesis is in northern Arkansas, along the Spring River that is fed by Mammoth Spring (Figure 1). The area of focus starts at Mammoth Spring and follows the river south down to Hardy, Arkansas. The geology in this area does not have many known geologic structures (McFarland et al., 2004). The bedrock formations consist primarily of early Ordovician Cotter and Jefferson City dolomites. The Jefferson City dolomite consists of a light to dark tan, fine grained crystalline dolomite (McFarland et al., 2004). It can also have some chert within the dolomite and is interlayered with thin beds of sandstones and shales. The Cotter

dolomite is a fine grained, argillaceous, earthy textured dolomite that can be relatively soft with a buff to gray color (McFarland et al., 2004). It can also be found as a more massive, mediumgrained, gray dolomite that weathers roughly and becomes darker on an erosional surface. McFarland et al. (2004) also report the Cotter to have chert, minor beds of a green shale, and some thin beds of sandstone. On the state geologic map of Arkansas, the USGS has the Cotter and Jefferson City dolomites formations mapped together as one unit on a scale of 1:500,000. 


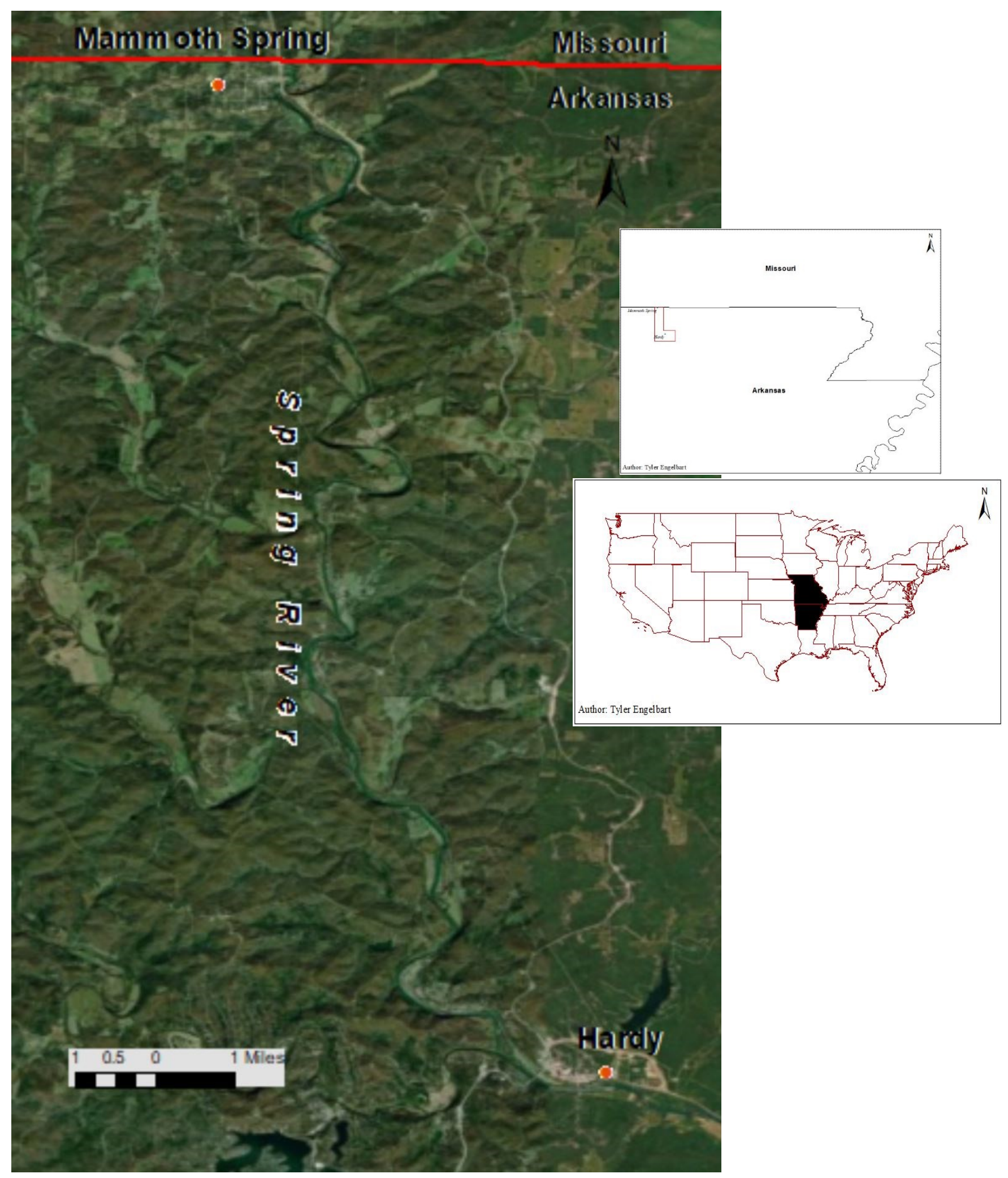

Figure 1. Satellite image of the study area in northern Arkansas. The main study area starts at Mammoth Spring and continues south to the Hardy area. 
The Mammoth Spring, which produces roughly 240 million gallons of water a day, feeds the Spring River. The Spring River is a meandering river system that has two main tributaries feeding the river. The two tributaries are the South Fork Spring River and the Warm Fork Spring River. The Spring River feeds into the Black River.

\section{Climate}

During the summer months in Harrison Arkansas, temperatures range from 75 degrees Fahrenheit at night to 90 degrees Fahrenheit during the day (NWS, 2018). During the winter months, the temperature is an average of 35 degrees Fahrenheit during the night to 50 degrees Fahrenheit during the day (NWS, 2018). In the spring and fall, the temperature ranges from 57 degrees Fahrenheit at night to 70 degrees Fahrenheit during the day (NWS, 2018). This area also has heavy amounts of rainfall from tropical storms or hurricanes that make it far enough inland. During the months of March and April, northern Arkansas receives its greatest amount of rainfall, which is roughly 12-16 inches of rain (NWS, 2018). The average rainfall for the year is about 44 inches (NWS, 2018). 


\section{METHODS}

Several methods were used in this project to investigate the tufa deposits on the Spring River. The first method used was aerial imagery. This was used to look at orientations of the deposits and a database was created for the trends of the tufa. The second method utilized was geophysical surveys. These were implemented to understand the extent of the deposits underneath the riverbanks. It was also used to locate any geologic structures next to the river. The third method was coring and core analysis. The coring was used to determine the vertical extent of the tufa. The core analysis was used to analyze growth patterns and to analyze the vertical structure of the tufa to see if it had a change from the top to bottom of the deposit.

\section{Aerial Data Analysis}

The tufa deposits in the study area were identified using ArcGIS in ArcMap 10.6. The World Geodetic System 1984 (WGS_1984) was used to keep data distortion to a minimum. A geodatabase was created to store all the layers in the map file in an editable format. The study area shapefile was edited using a polygon tool, and then a shape was drawn around the focus area of the river. A new shapefile was then created for the tufa deposits in the study area, and all the deposits were marked within the study area using the tufa shapefile.

In the study area, field testing locations were chosen at a search elevation of about 7,000 meters (m) above the surface using Google Earth. This elevation allowed for both sides of the river to be viewed at one time. The field-testing locations were picked by looking for an open plot of land that would allow for easy access to the river. The easy access was considered to be an accessible road or a farm field. Each open plot of land needed to be wide enough to perform 
multiple geophysical surveys next to the riverbank. The location also needed to have a tufa structure leading up to the bank of the property.

Using Google Earth, an estimated width, length, and trend of the tufa were recorded in an Excel spreadsheet. The estimated width and length were obtained using the Google Earth measuring tool, and the trend was taken with a protractor on paper with the paper oriented correctly. For the trend, the deposits were sometimes broken up into different segments depending on how sharp of a turn the deposit took in the water. The sharpness of the turn was determined by how much of a deviation it had from the overall trend of the deposit. This data was entered into an excel file (Appendix A).

Rose Diagram. The data for the tufa deposit trends was converted into a rose diagram using the program Stereonet 10 (Allmendinger, 2006). The instructions for converting the data to a rose diagram can be found in Stereonet 10 (Allmendinger, 2006). The bin size was set to five. The degree of separation was set at ten degrees between each bin.

\section{Geophysical Surveys}

Electrical Resistivity (ER) is based on Ohm's Law, which states that the current $(I)$ in amps, flowing between two points is equal to the potential difference $(V)$ in volts, divided by the resistance $(R)$ in Ohms (Reynolds, 2011).

Three locations were chosen along the Spring River for the geophysical surveys. All the surveys were conducted on generally flat-lying ground, in a floodplain area, and near a meander of the river (Figure 2). The floodplain of the river was chosen for putting in the electrodes because of the loose topsoil. 


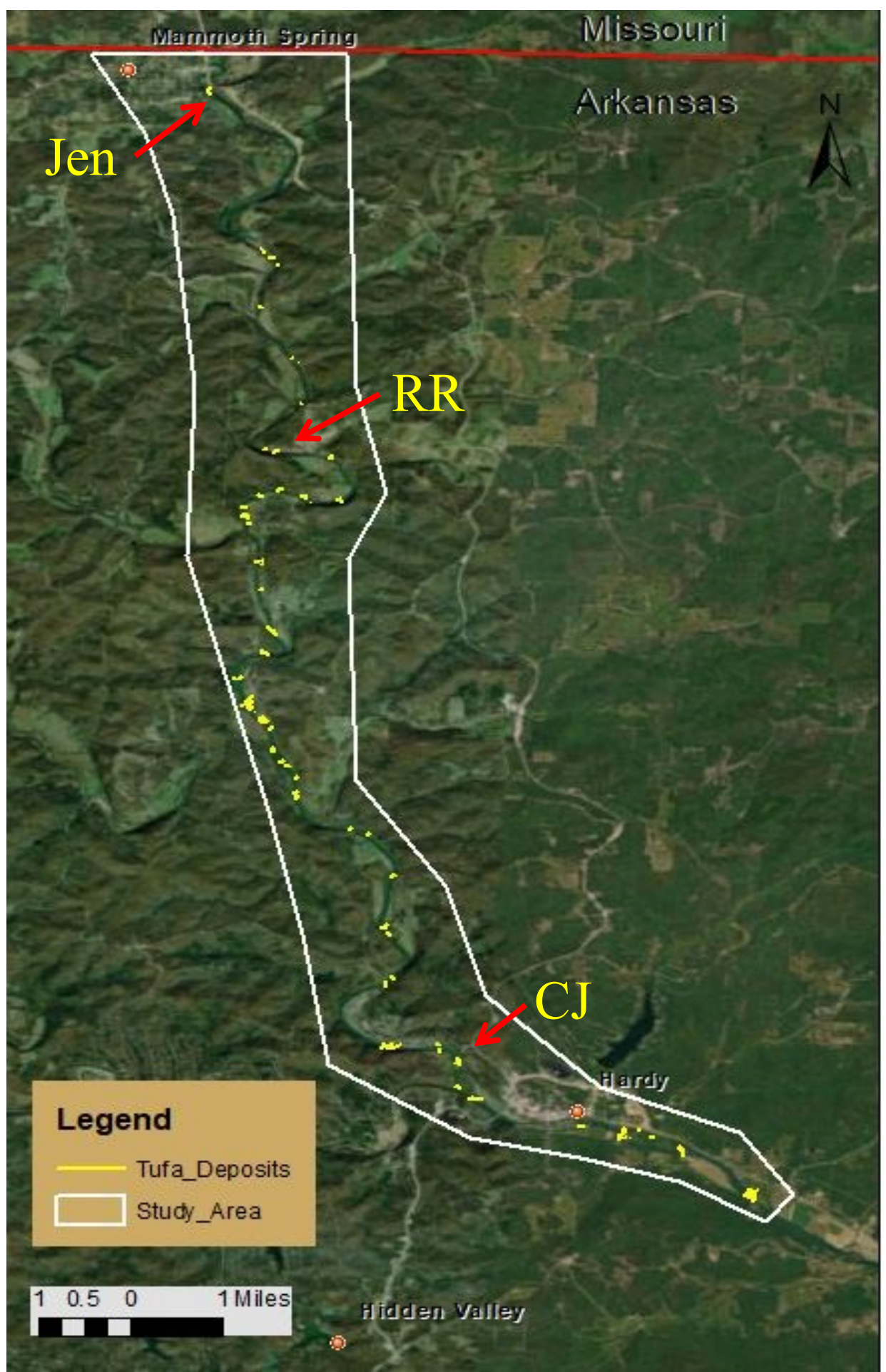

Figure 2. Satellite image of the study area for geophysics (white polygon). The yellow marks in the study area are visible tufa deposits in the river. Jen, RR, and CJ are specific sampling locations for geophysics. 
The data was collected using a GF Instruments Automatic Resistivity System (ARES) with a 64-electrode configuration. The electrodes were spaced at one meter for all of the surveys. The power source for the system was a deep cycle Optima marine battery. At each location, the first survey performed was oriented perpendicular to the tufa deposit and the deposit was placed roughly in the middle of the survey. The second survey at each location was shifted away from the water's edge and roughly parallel to the first survey.

Location one was roughly $2 / 3$ of a mile downriver from the mouth of Mammoth Spring; it had two lines of ER, with both lines conducted using dipole-dipole arrays (location named Jen). Line one was conducted two meters from the riverbank, and line two was shifted back five meters. Location two was roughly six miles downriver from the mouth of Mammoth Spring, at Riverside Resort Camp and Canoe (RR). Location two had two lines of ER conducted. The first line was a dipole-dipole array conducted two meters away from the riverbank. The second line was a Schlumberger array and it was shifted back five meters and downstream six meters. Location three was roughly seventeen miles downriver from the mouth of Mammoth Spring on Circle J Farms (CJ) property. Location three had two lines of ER conducted and VLF-EM. The first line was a dipole-dipole array conducted two meters from the riverbank. The second line was a Schlumberger array and it was shifted back fifteen meters, thirteen meters upstream, and it was not directly parallel to the first survey. The data was stored in the unit and brought back to Missouri State University for download and processing.

Data processing was done for each survey by downloading the data to a computer using GF instruments software and then converting into a format that is readable by AGI Earthlmager $2 \mathrm{D}$ software. The program ran the necessary tests to create a $2 \mathrm{D}$ resistivity profile that shows subsurface data in colors. The colors represent the difference in the resistivity of that material 
(red is high, and blue is low). The study area has no previous geophysical surveys to compare the data collected.

\section{Coring}

Locations where coring was to take place were selected using Google Earth and access considerations. The location needed easy access to the water's edge for all the equipment. When locations were picked, the size and orientation of the tufa was also taken into consideration. The tufa needed to be large enough to core several spots. After the locations were chosen (Figure 3), permission was obtained to access private properties.

The local state park at Mammoth Spring helped in contacting local landowners. The landowners were contacted to gain consent. They were also able to help arrange contact with surrounding landowners which proved very valuable. A flyer was handed to the landowners to give information on what the project was about and the tests to be conducted (Appendix B). Once verbal consent from the landowners was obtained, field work was scheduled.

The Missouri Geological Survey (MGS) was kind enough to loan us their Shaw Backpack Drill. It had four core barrel extensions, two barrels with coring bit, and two corecatcher barrels. The MGS supplied a new Elephant Tooth core bit with loan of the drill.

Proper permits were obtained from the U.S. Army Corps of Engineers and the Arkansas State Department of Environmental Quality. The permit number for this project was USACOESWL-2019-00140 and ADEQ-STAA No-20190212. In addition to permits for the in-stream drilling, plans for field safety during drilling were developed. 


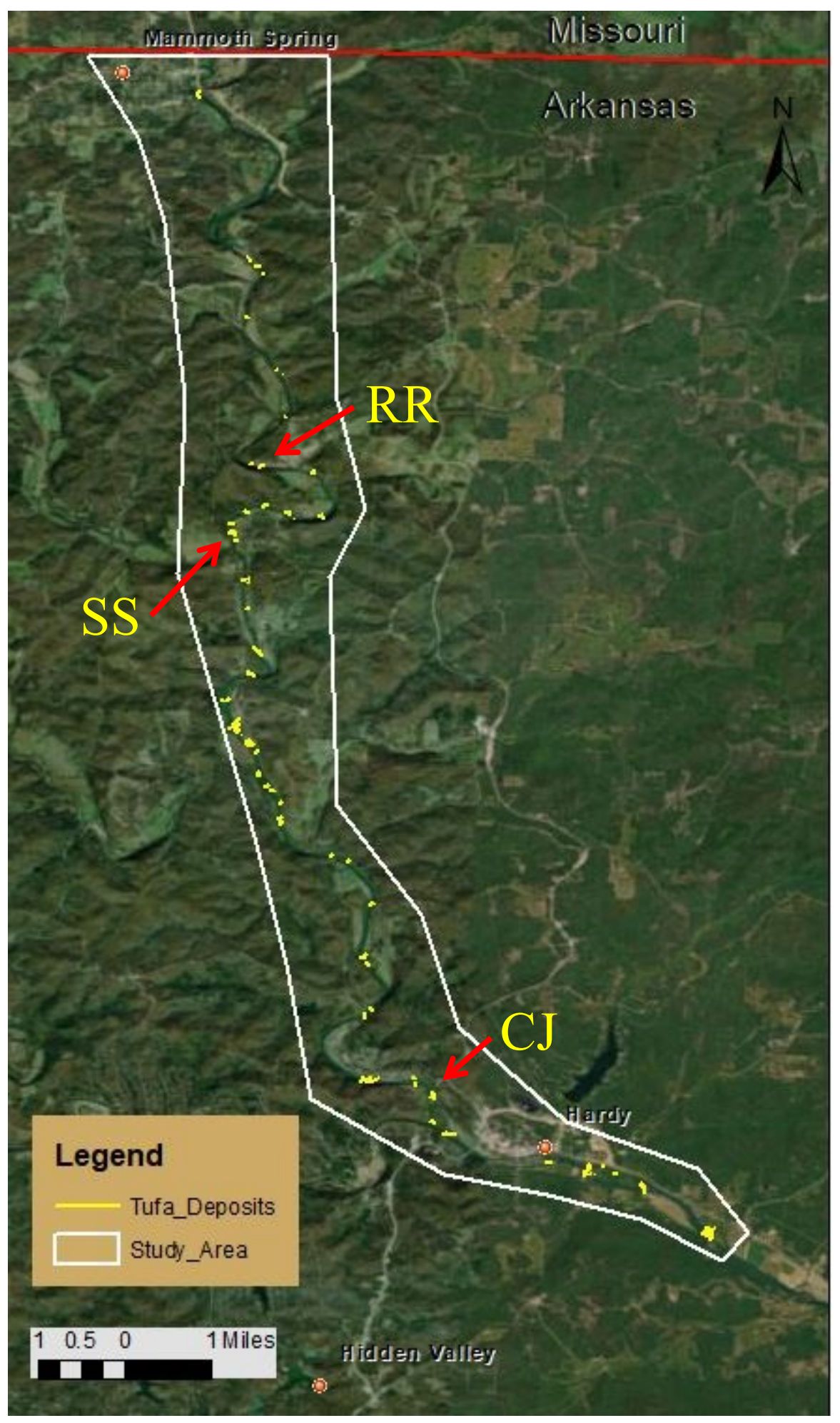

Figure 3. Satellite image of the study area for coring (white polygon). The yellow marks in the study area are visible tufa deposits in the river. RR, SS, and CJ are specific sampling locations for coring. 
The Arkansas State Survey was notified of the days that coring was going to take place so that they could be there to review the core samples. The Arkansas Parks and Wildlife Fish Hatchery was also contacted to coordinate a time they could lower the water during the coring process. This helped to ensure the water was at the lowest level possible.

Before coring started, a spot on the deposit was chosen by finding a divot that would allow the drill bit to grab. A GPS location was taken at this time on a handheld Garmin GPS to locate the core hole approximately plus or minus 10 feet laterally. Coring breaks were taken to remove core from the core barrel and measure the depth of the core hole and place the core into the box (Figure 4). During each break, a block was put in the core box marked with the run number and the measured hole depth which helped to note where possible core loss could be. This method was not done at the first coring location at Riverside Resort Camp and Canoe. Each sample piece was marked with a Sharpie permanent marking stick to mark the top of each piece of core. Once the coring was completed at that location, a picture of the core box was taken to keep track of placement of the core in case of movement during travel. The core box was also labeled for the top of the box, what the core number was, and at what location the core was taken from. When coring was completed, the core was taken back to the lab and the core boxes were left open for a few days to dry. After the core was dry, a spread sheet in excel was used to log the core (Appendix C). Field notes were added into the description of core hole depth, location of the core, and where core sample length did not match up with core hole depth. 

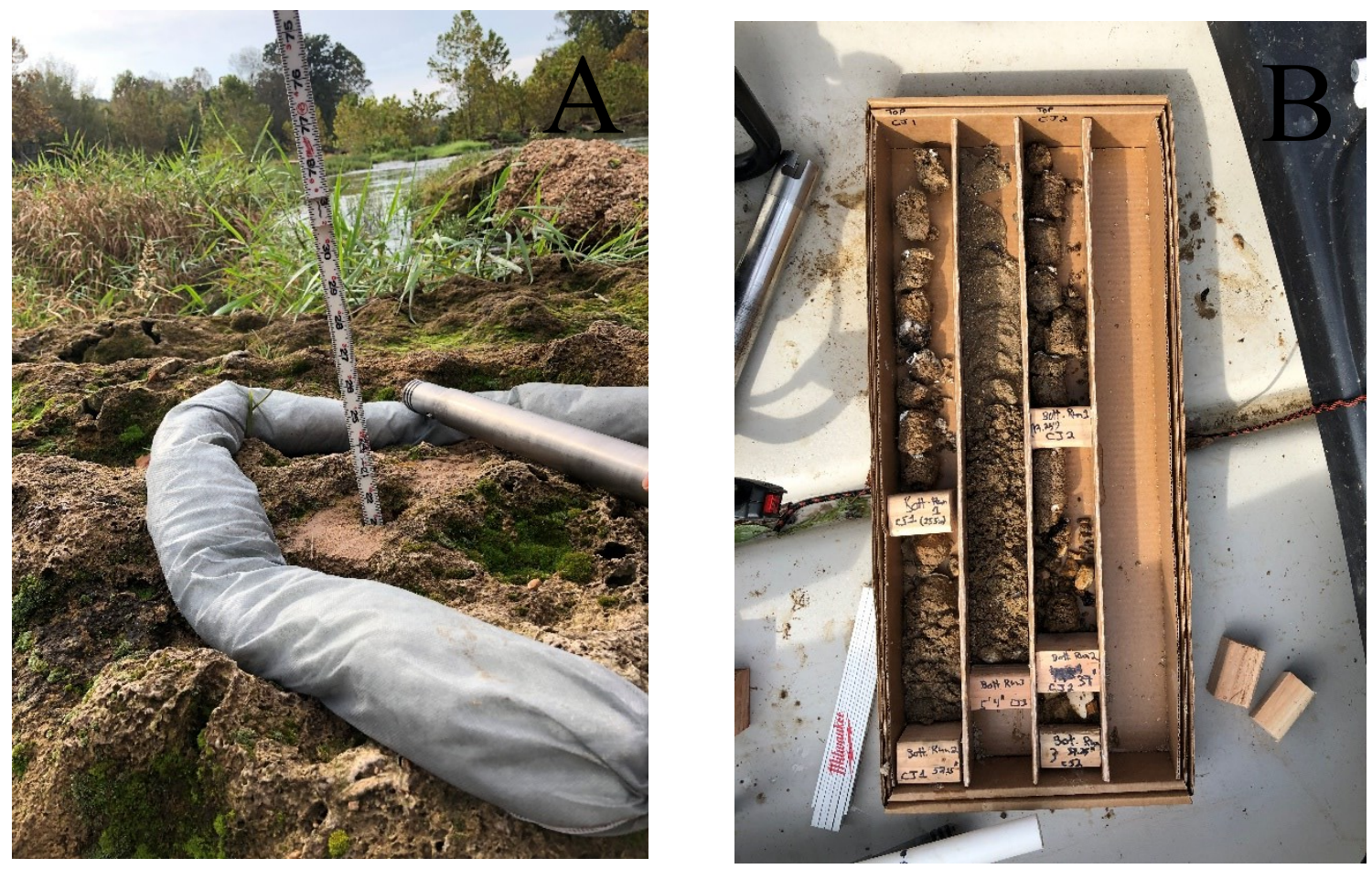

Figures 4. A) General surface texture of the tufa and how the measuring stick was used to note the core hole depth. B) How the core samples were placed into the core box, marked with the white to denote top of sample, and how the blocks were put into place with a given core hole depth.

\section{Core Photograph Analyses}

Core photos were taken with a Canon 5 DSR and an ef 24-105 mm 1:4 LISUSM lens. A Pholsy remote was used to capture the photos so the camera was not touched once set. The shutter speed of the camera was set to 0.3 seconds. The aperture of the camera was at $\mathrm{f} 22$. The flash used was a 600 EX II-RT at a 45 -degree angle up and set at +2.3 overexposing with a diffuser on the flash. A black back drop was used to better offset the light versus dark colors in the samples. The samples were set up on a sample holder (drill bit) at eighteen-inch distance from the camera. 


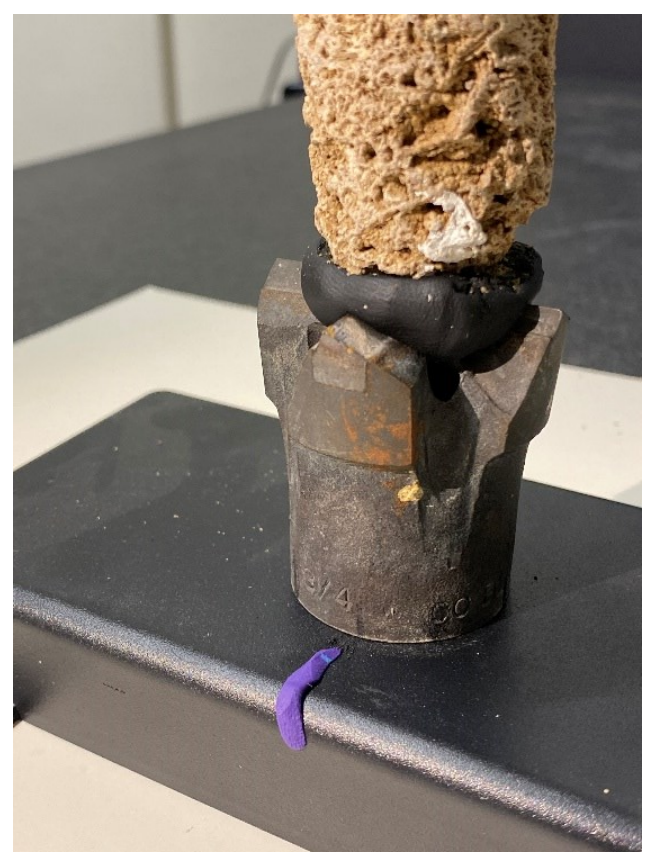

Figure 5. Pencil marks on the sample holder were used as a known location along with a known reference point marked on the base (as marked in purple putty) for rotating the sample.

When taking the pictures, the sample holder was marked in eight locations for a known reference to turn the holder each time (Figure 5). There were eight pictures taken with the camera at the same location. The orientation of the core was rotated in a counterclockwise direction for each new picture. Only whole samples that were large enough to photograph and then analyze were photo documented. Before each new set of pictures were taken, a sample photo was taken of a cover sheet to sort what sample it was and what the sample number was.

The photos were plugged into a program called ImageJ, version $1.52 \mathrm{~s}$ to get a surface porosity (Rasband, 2019). In this program, the background needed to be removed to analyze each sample. To remove the background, one must open ImageJ, open the image in ImageJ, click the polygon selections, click edit, and then click clear outside (Figure 6). This was done for all eight samples to be able to process them. 


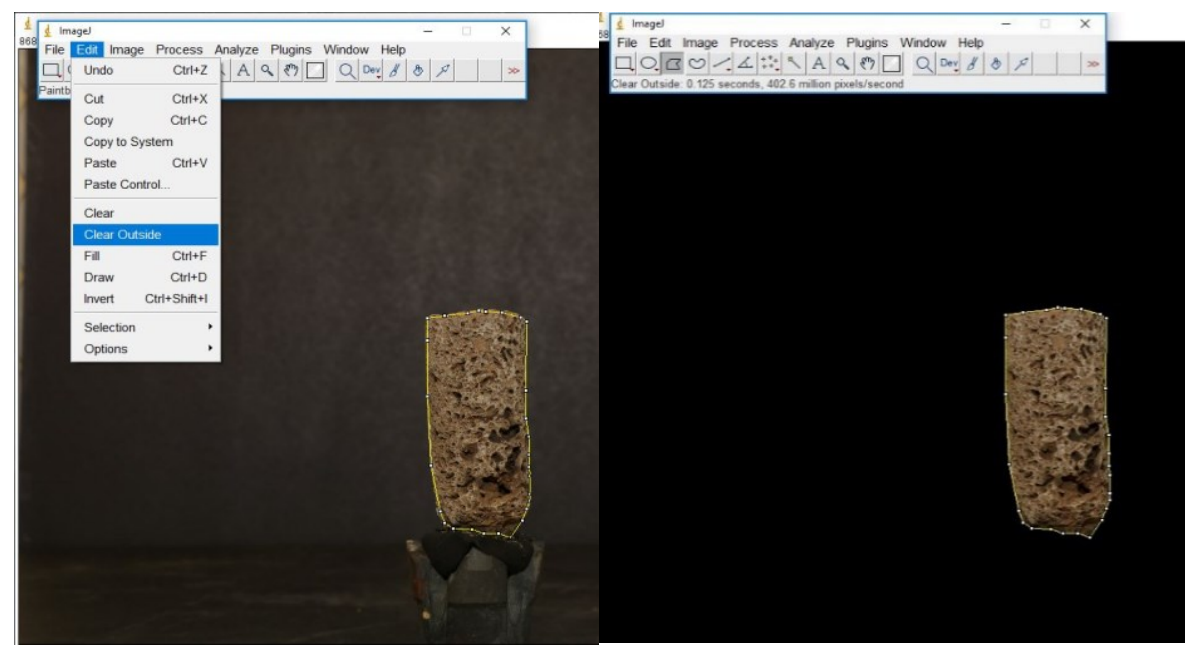

Figure 6. Detailed process on the tools used to clear out the background of a photo so that it can be processed in Imagej.

Once the background was cleared from the sample, it could be processed in the program to find a surface porosity of the sample in the picture. To be able to run the tool, the image needs to be converted to an 8-bit image, because the program reads the difference between the gray scale contrasts in the image. To convert to an 8-bit image click Image, click Type, and click 8-bit (Figure 7).

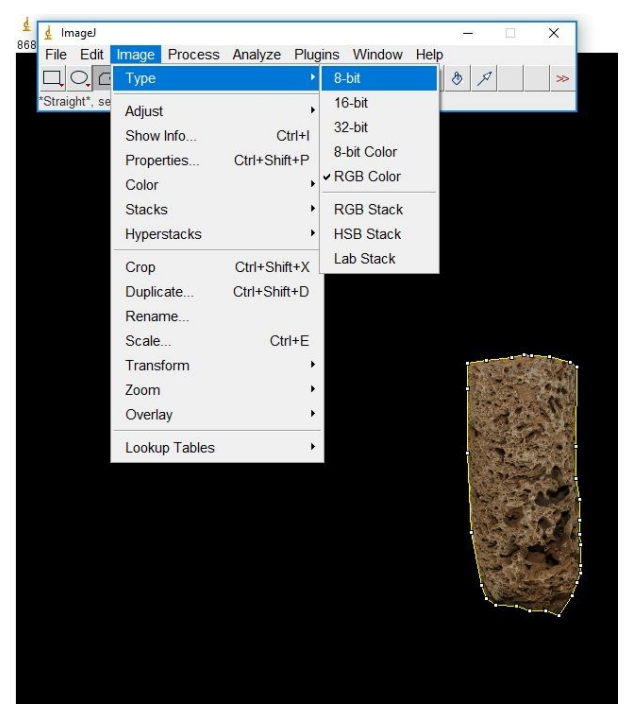

Figure 7. Tools used to convert an image from RGB color to 8-bit image for analysis in the software. 
Once the image has been converted to an 8-bit, it can then have an Auto Threshold run on the image which takes into consideration the different grey color scale to get an average porosity. In the program, to run the auto threshold click Image, then click Adjust, and then click Auto Threshold. Once the Auto Threshold is chosen, a dialog box pops up asking to choose the method, ignore black and/or white, white objects on black background, set threshold instead of threshold (single image), and show threshold values in log window. For methods, choose Percentile, ignore white (since on a black background), white objects on black background (the background is removed and set automatically to black), and then choose show threshold values in $\log$ window (Figure 8).

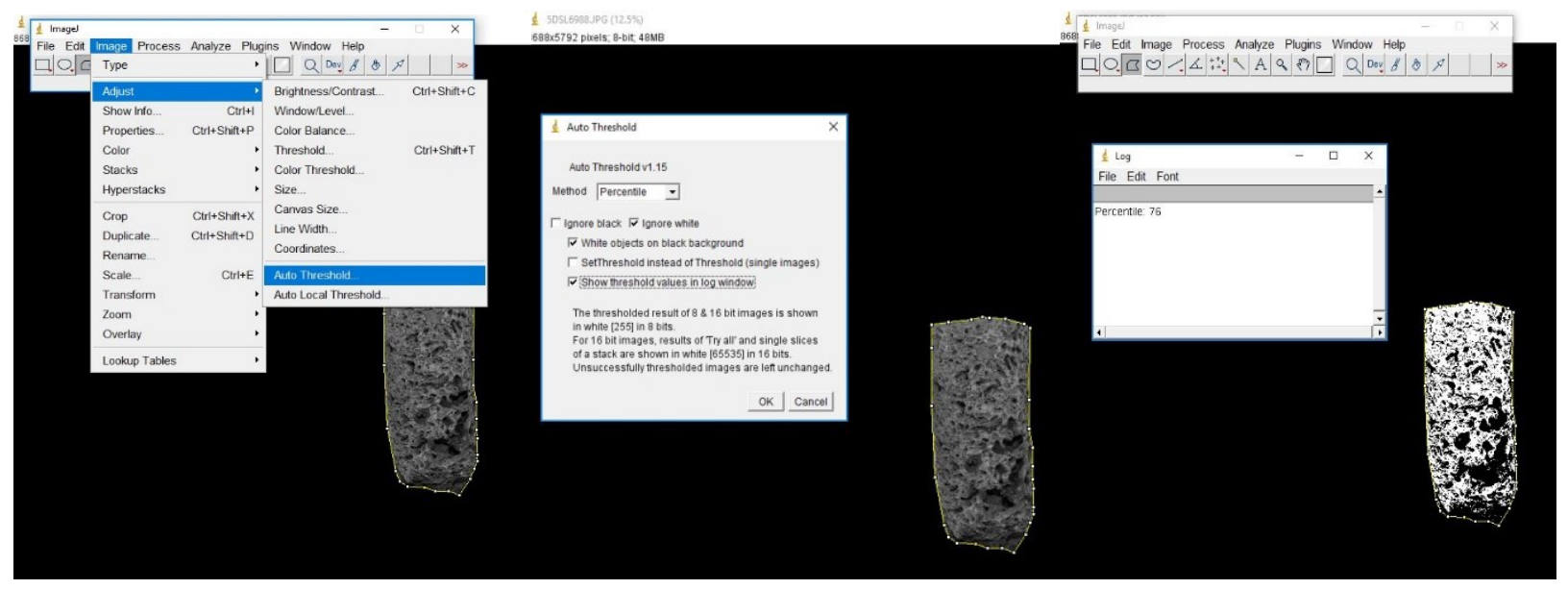

Figure 8. Steps used to perform an auto threshold, how to get all the correct settings for the image, and how to get the bin number to calculate porosity.

The image that comes out of the auto threshold, as seen on the far right in figure 8 , has the porosity in black and the surface in white. The value that is shown in the value box is 76 but that is the number of bins in the photo and the total count of bins is 256 . To get the value for porosity this formula was used $(76 / 256) * 100$ and it gave $29.7 \%$ as the porosity. This was done for all eight photos of this sample and then an average was taken to estimate the average porosity of the sample. It has about a 5\% error for the porosity but that is due to the digital processing of 
the image. This process was done for all the cores taken except for the samples that were too small to analyze in the computer program. Once the average was taken it was plugged into the core $\log$ of the tufa for that sample.

\section{Thin Sections and SEM Analysis}

Thin sections were made from samples of the first core box to look at the structure of the tufa. The samples chosen were the more durable samples that would not crumble when being split. The four sample pieces chosen were from different locations (depths) throughout the core box. Only the first box was thin sectioned because it had longer samples and to preserve the other sample boxes. The samples chosen were without shells so that the location of the shells were preserved in place on the core for a later study.

Thin sections were made by splitting the core in half and cutting that section in half to fit on the thin section slide. Once cut to size it was polished to remove saw marks and this was done by hand using 320 grit, then 600 a grit, and then a 1000 grit. The polished sample was then epoxied to a thin section slide. Once epoxied to the slide it was then cut and ground down to the correct thickness using the Michel Lévy Chart. When the polishing of the thin section was complete the thin slipcover was epoxied on. The sample was then marked to indicate the top of the sample and the sample number.

SEM work was done on the blanks left from thin sectioning. The samples were slightly polished with 320 grit to remove the saw marks. The samples were coated in gold (following the Missouri State Physics Department guidelines) to keep the sample from charging while looking at them in the SEM. They were mounted to $3 / 4$ " stages with carbon tape on the bottom and then 
copper tape on the sides to hold it to stage. Once placed in the SEM the Missouri State Physics Department guidelines were followed to run the SEM. 


\section{RESULTS}

\section{Imagery Analysis}

Using the measurements from the tufa deposits that were gathered using Google Earth a large data set was produced $(\mathrm{N}=168)$. A rose diagram of the data is in Figure 9. The dominant trend is oriented at $055^{\circ}$ followed by a second trend at $355^{\circ}$. This gives one northeast to southwest trend and a lesser north to south trend.

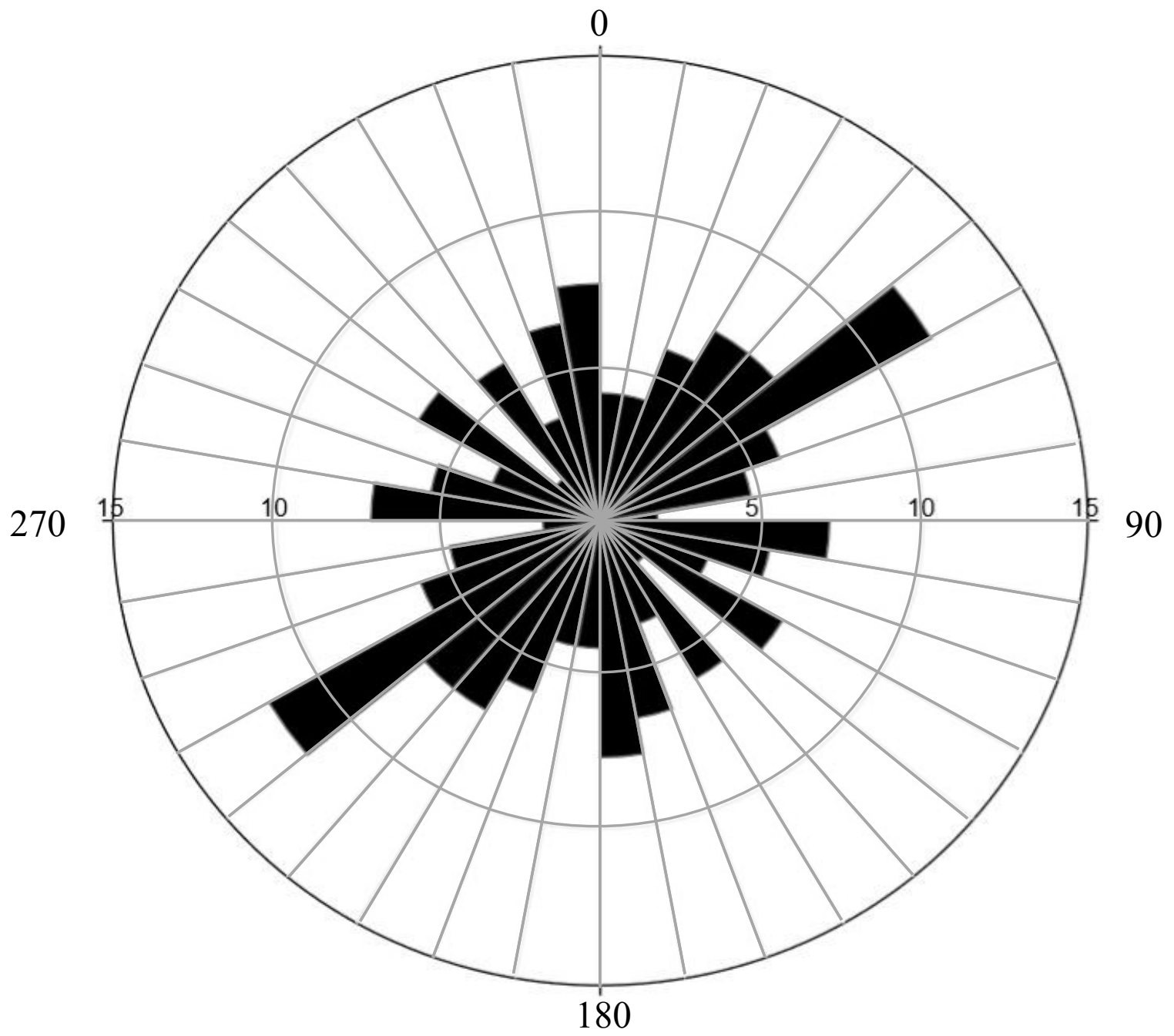

Figure 9. Rose Diagram created from general trends of the tufa deposits in the Spring River. North is at the top $\left(0^{\circ}\right)$. 


\section{Geophysics}

Jen (a \& b). Two profiles were collected parallel to the Spring River and roughly perpendicular to the tufa deposits (Figure 10). The first profile, Jen-a was collected about two meters from the water's edge and profile Jen-b was collected about five meters from the water's edge.

The results of Jen-a are in Figure 11, with raw data, processed data, and the final model. The results of Jen-b are in Figure 12, with raw data, processed data, and the final model. The final models for both surveys were calculated using a two-dimensional inversional algorithm where the final model is determined in an iterative least-squared method until the root mean squared (RMS) error cannot be lowered (Schwarzbach and Spitzer, 2005). Typically, the process takes three to six iterations.

The final model of profile Jen-a (Figure 11c) has a large RMS error (16.39\%), possibly due to being so close to the river. The RMS error (3.47\%) of Jen-b (Figure 12c) model is typical of good data. Jen-a and Jen-b both have a high resistivity (red to orange color) value underneath the tufa. There are breaks on both sides of the high resistivity signal showing a lower resistivity value (green-blue color).

RR (a \& b). The second location (Figure 13) was at Riverside Resort Camp and Canoe (RR). RR-a was conducted approximately two meters from the water's edge, and RR-b was conducted approximately seven meters from the water's edge (Figure 13). At this location, RR-a was a dipole-dipole configuration and RR-b was a Schlumberger configuration. The two lines are offset from one another due to limited space along the riverbank. Both surveys had a very low RMS error value which shows good quality data. 
The results from RR-a are shown in Figure 14. The results from RR-b are shown in Figure 15. Both RR-a \& RR-b have the raw and two processed sets of data. The final model for RR-a has three high resistive anomalies in the survey about three meters deep (Figure 14c). The final model for RR-b has two high resistive anomalies (Figures 15c). There was no exposed rock at the surface for this location.

CJ (a \& b). The third location (Figure 16) is at Circle J Farms (CJ). The set up was the same as site RR, where CJ-a is a dipole-dipole and CJ-b was a Schlumberger array. CJ-a was conducted roughly two meters from the water's edge and CJ-b was conducted roughly sixteen meters away from the water's edge (Figure 16). The two lines were offset from one another due to a fence along the river's edge. The first survey, CJ-a, is very similar to RR as the higher resistivity value is roughly four meters deep. The lower resistivity is between the high resistive anomalies (Figure 17c). For the second survey, CJ-b, there is no break in the high resistive value, and it is roughly five meters deep (Figure 18). The resistive layers are relatively flat lying. Very-low Frequency Electromagnetic (VLF-EM) data was collected at the CJ site due to the available space in the open field (Figure 16). VLF-EM data was collected parallel to the river and in the flood plain. The data was collected using a GEM system receiver and a GPS receiver to obtain the latitude and longitude of each VLF-EM station taken. The stations were collected every two meters along each profile. The data was collected using the $24.6 \mathrm{KHz}$ broadcasting station in North Dakota. The VLF-EM data is sensitive to electrically conducting materials in the subsurface. The depth the signal penetrates is approximately 100 meters at the maximum. The VLF-EM receiver collects the real [in-phase (IP)] and imaginary [out-phase (OP)] components of the electromagnetic field. Figures 19a and 19b show color images of the IP and OP data. 
The red IP values represent regions of lower conductive material which may be related to near-surface water. The most pronounced feature is the roughly linear feature $(\leftarrow>)$ as seen in figure 19a. This lower conductive region maybe a fracture.

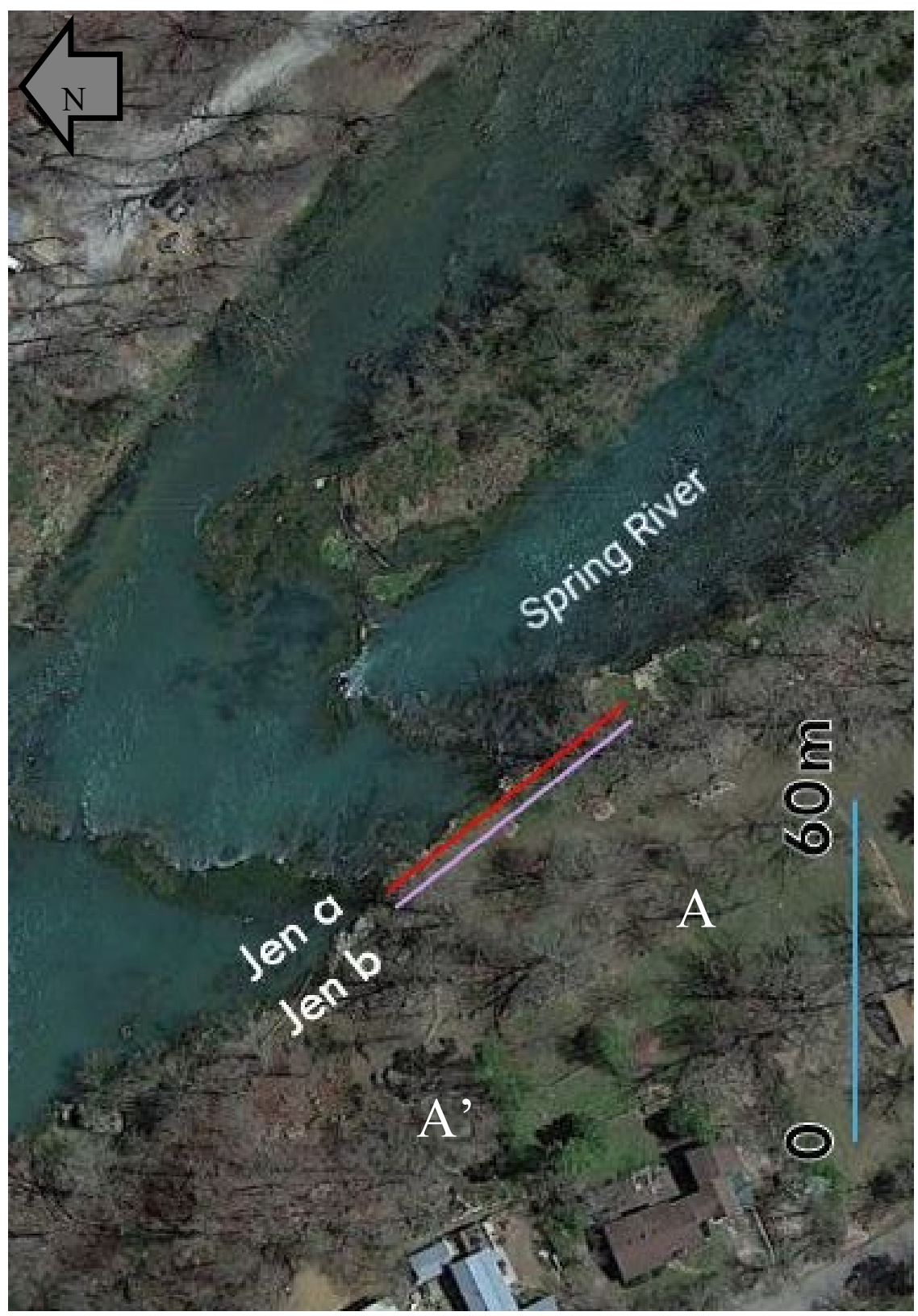

Figure 10. Satellite image showing the location of first geophysical site just outside of Mammoth Spring (Jen a and b). The two surveys are shown parallel to the river and are perpendicular to the tufa deposits. Jen a, shown by the red line, is closest to the river. Jen-b, shown by the purple line, is further away from the river. The letters A and A' correspond to the letters in Figure 14 and 15. 


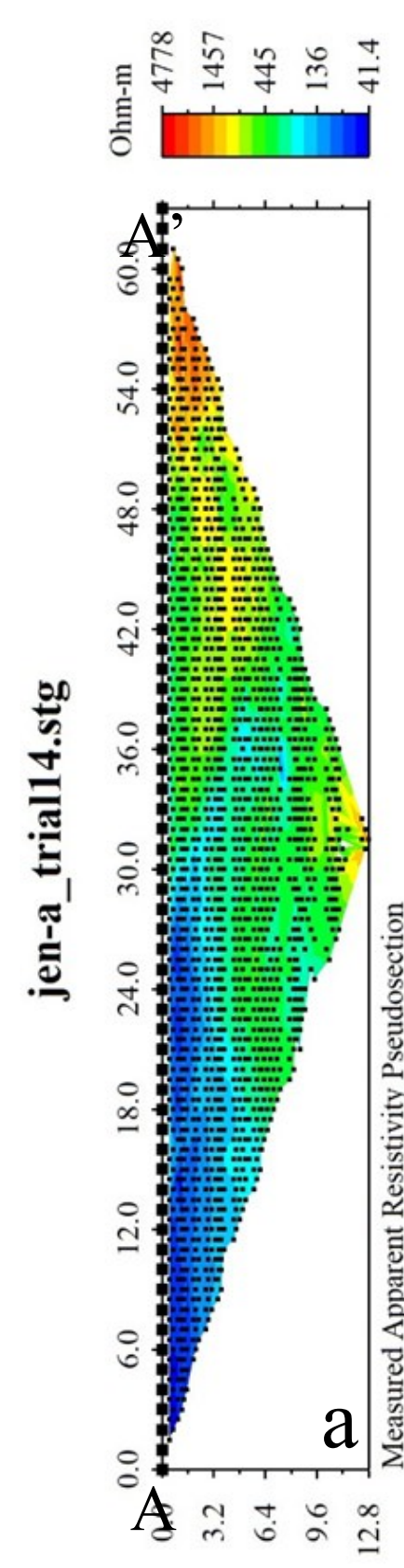

(ui) प1dəC
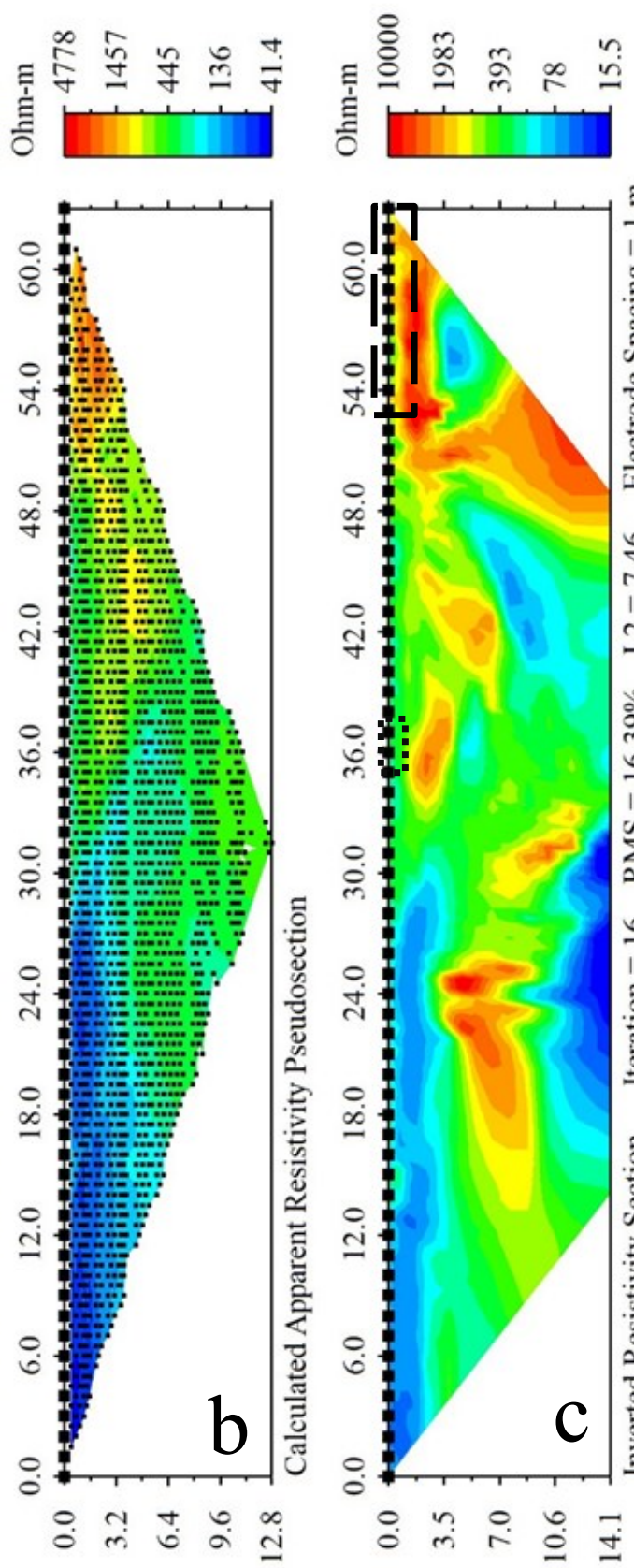

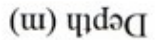

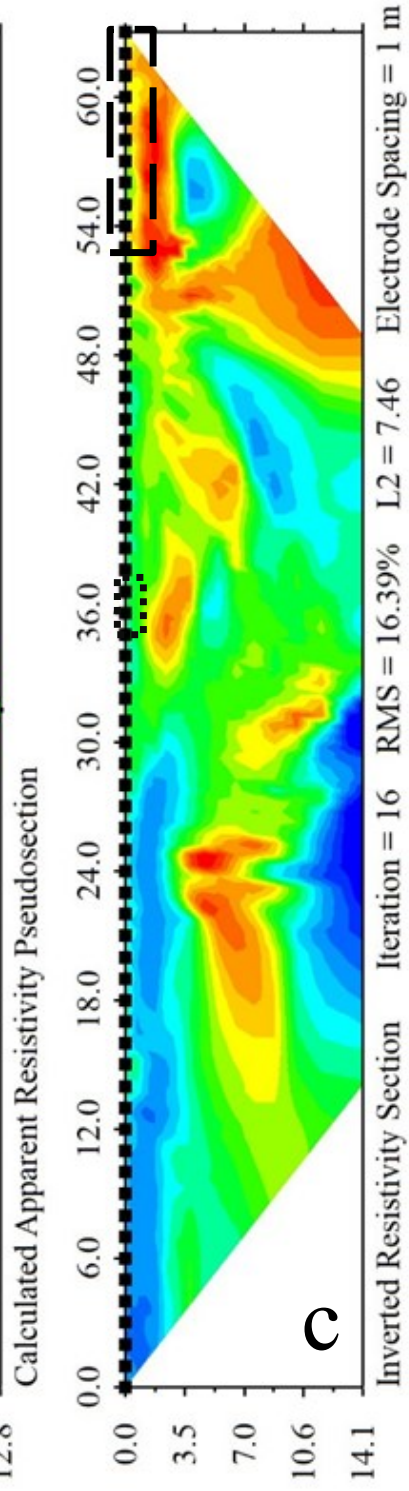

(ui) प1

Figure 11. a) The collected geophysical data from survey line Jen-a. b) The calculated model of the collected data. c) The final model produced from the calculated model. The tufa deposit location is depicted by small dashed box (:.:: $)$. The heavier dashed box to the right side of the model is showing where rock was exposed at the surface. The RMS value for the survey is $16.39 \%$. 


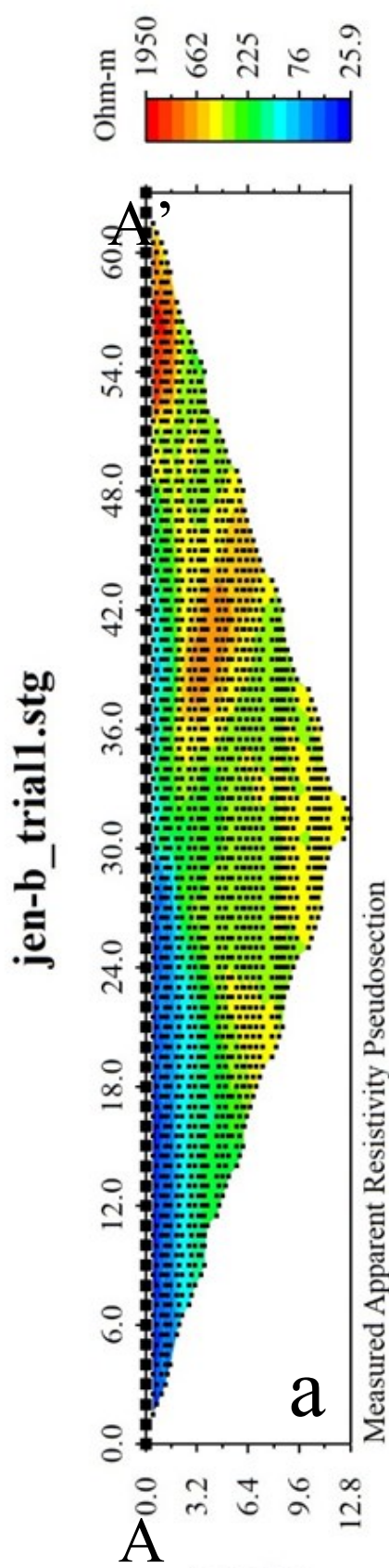

(ui) чาdə
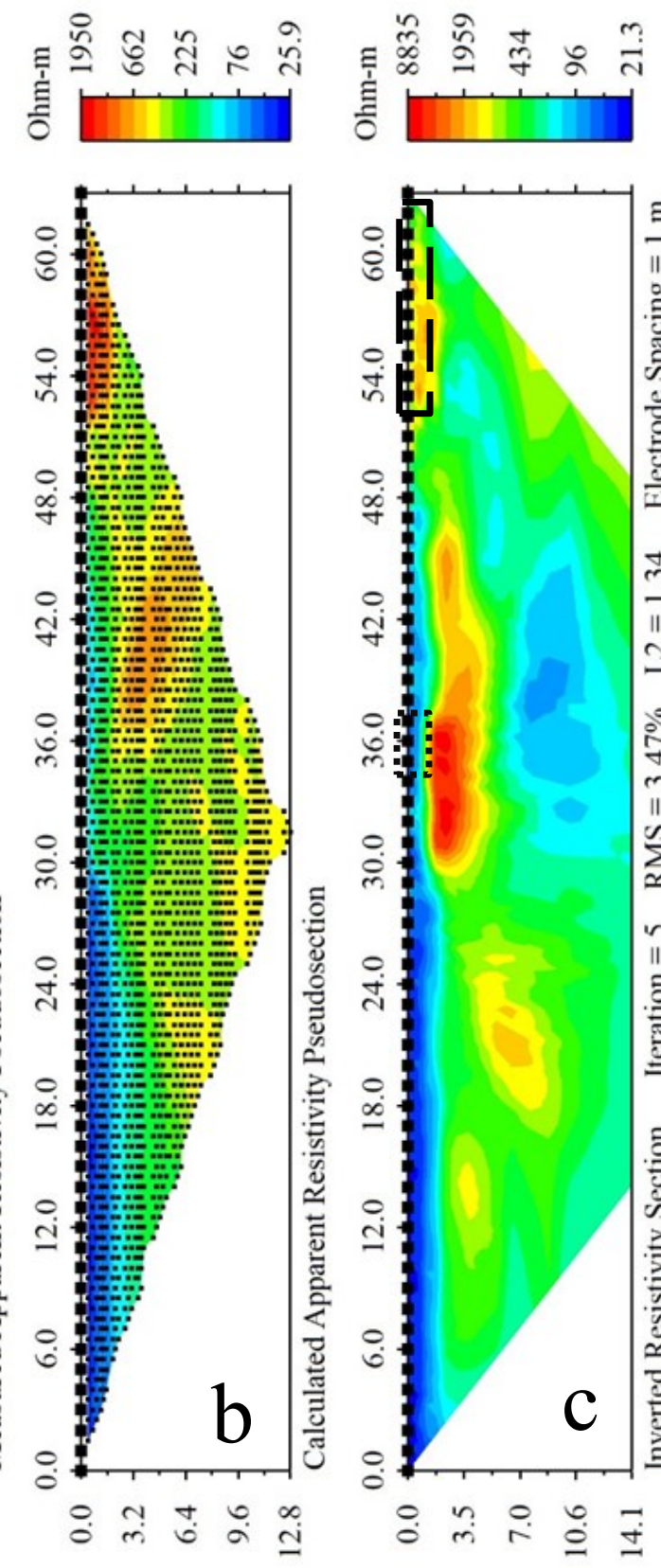

(u) पाdəव

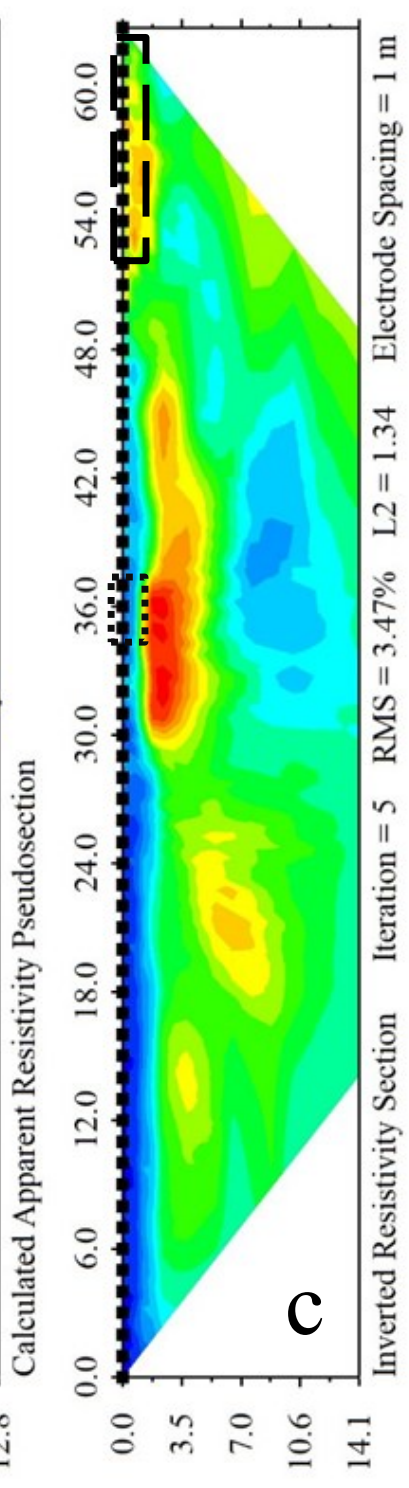

(שi) ч)d॰

Figure 12. a) The collected geophysical data from survey line Jen-b. b) The calculated model of the collected data. c) The final model produced from the calculated model. The tufa deposit location is depicted by small dashed box. The heavier dashed box to the right side of the model is showing where rock was exposed at the surface. The RMS value for the survey is $3.47 \%$. 


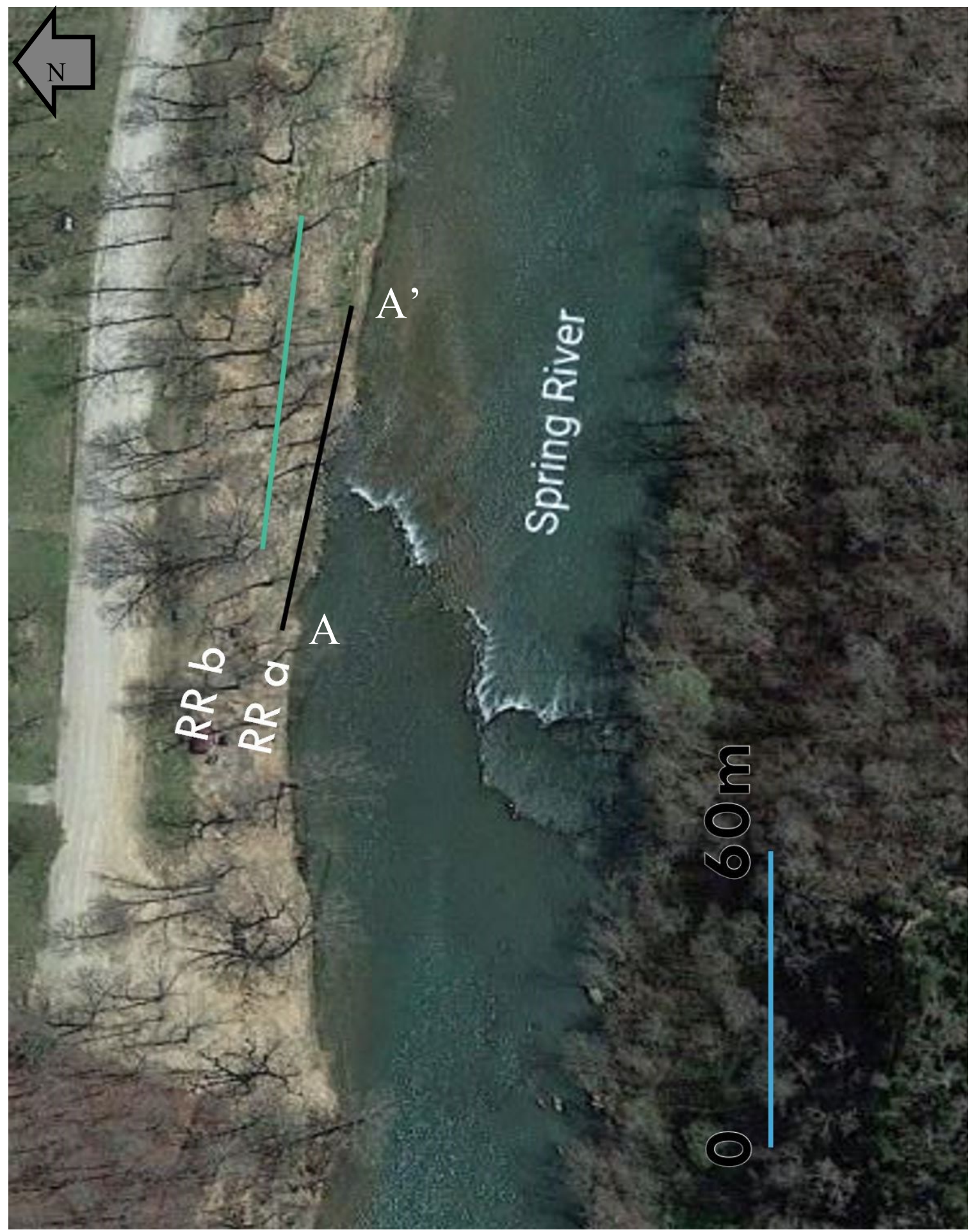

Figure 13. Satellite image showing the location of second geophysical site at Riverside Resort Camp and Canoe ( $R R$ a and RR b). The two surveys are shown parallel to the river and are perpendicular to the tufa deposit. RR $a$ is closer to the river and shown by the black line. RR $b$ is further away from the river shown by the teal line. The RR-b profile was shifted to the east due to a large bank drop off about two meters from the road. The letters A and A' correspond to the letters in Figure 15 and 16. 


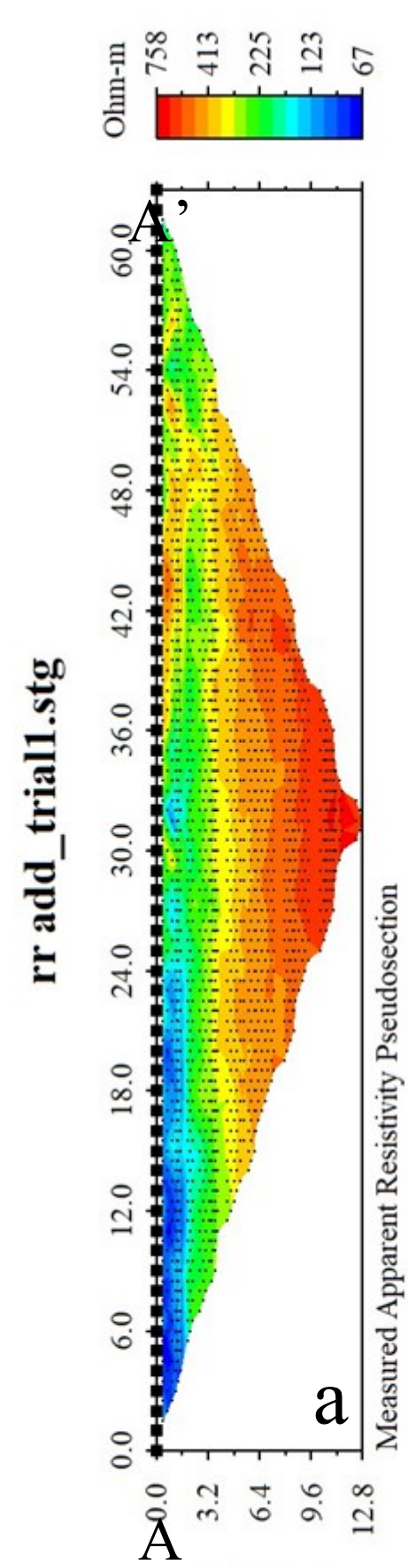

(ui) ч1рәа
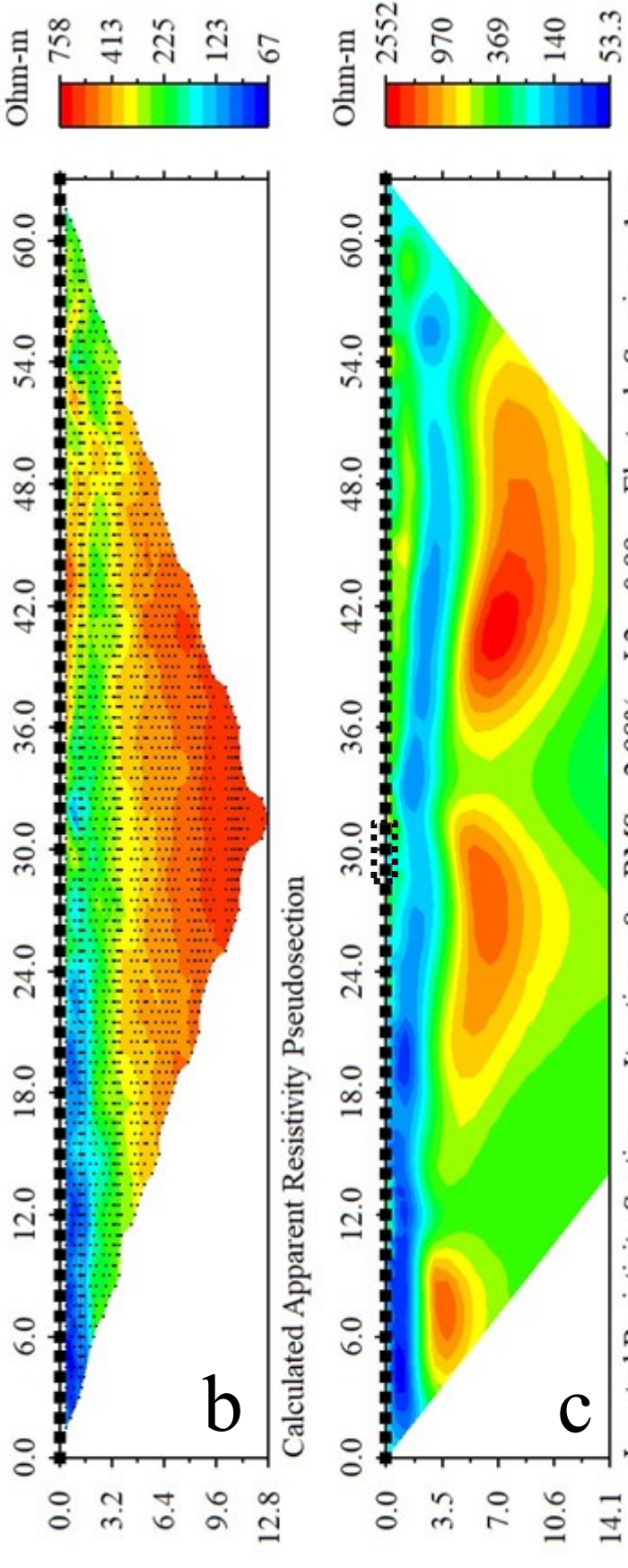

(ui) чрдәव

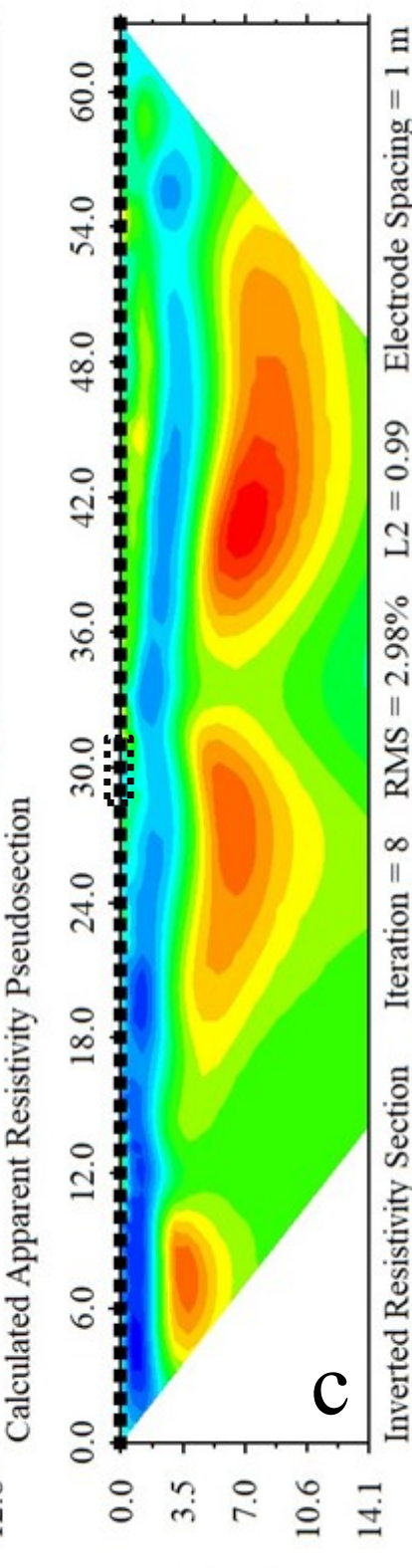

(ui) чрдәव

Figure 14. a) The collected geophysical data from survey line RR a. b) The calculated model of the collected data. c) The final model produced from the calculated model. The tufa deposit location is depicted by small dashed box. The RMS value for the survey is $2.98 \%$. 


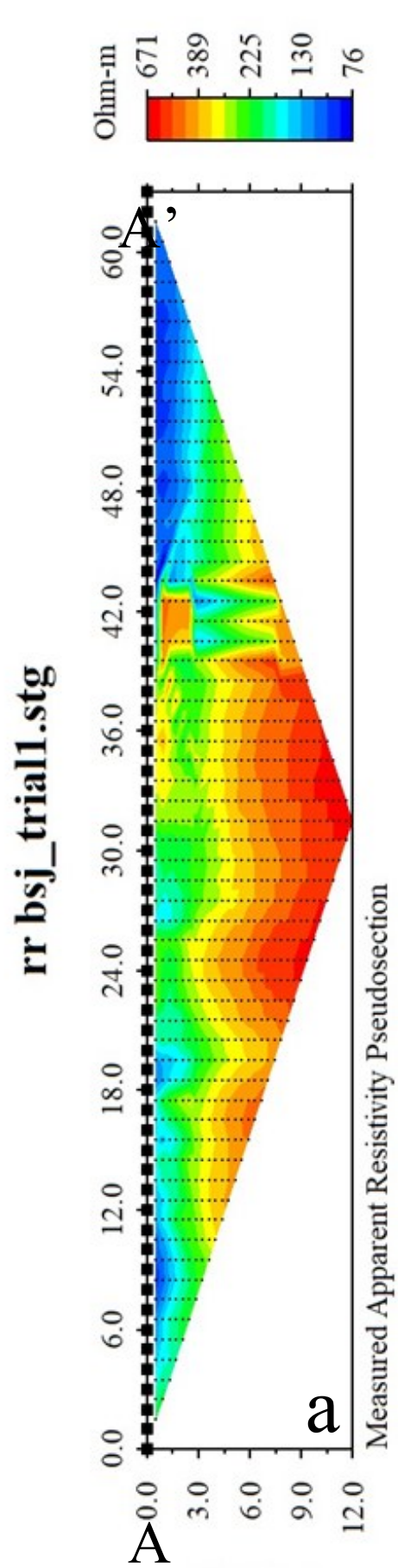

(ui) प1मәब
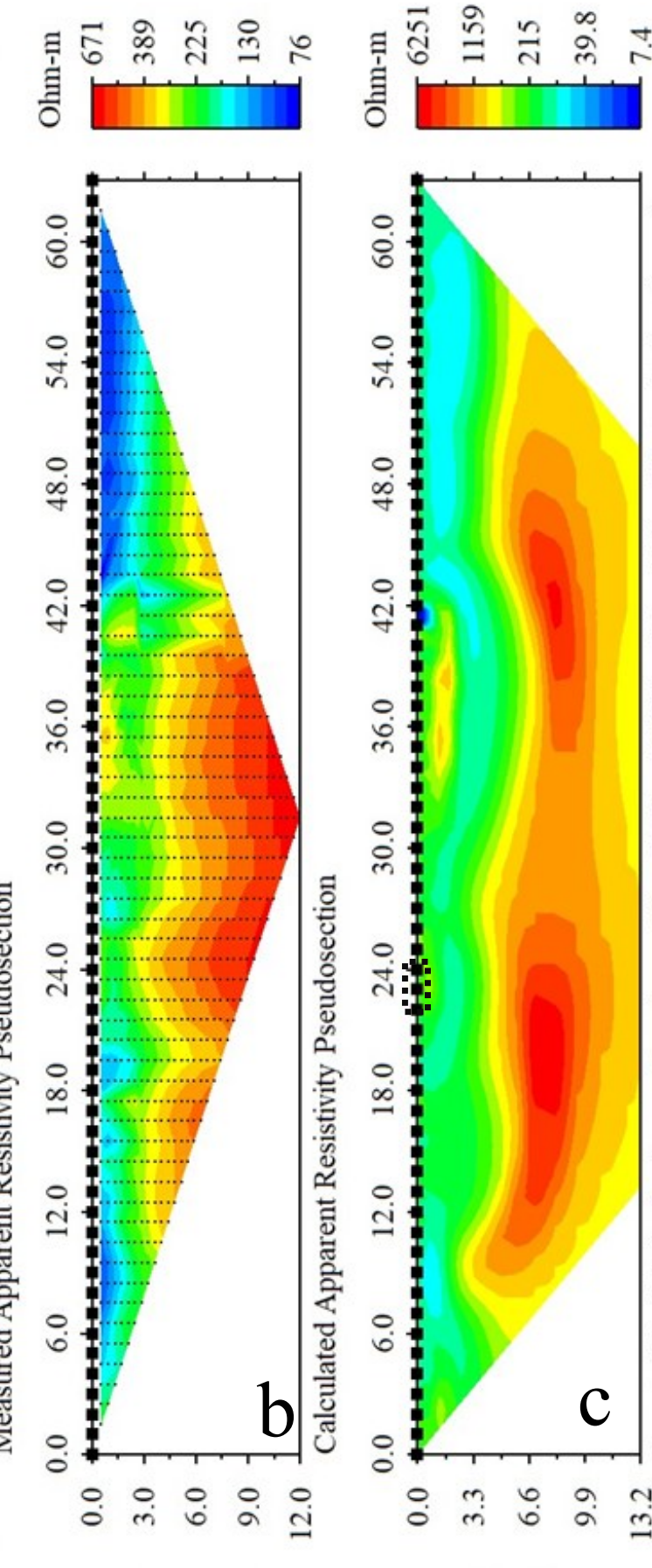

(uI) पрdә्व

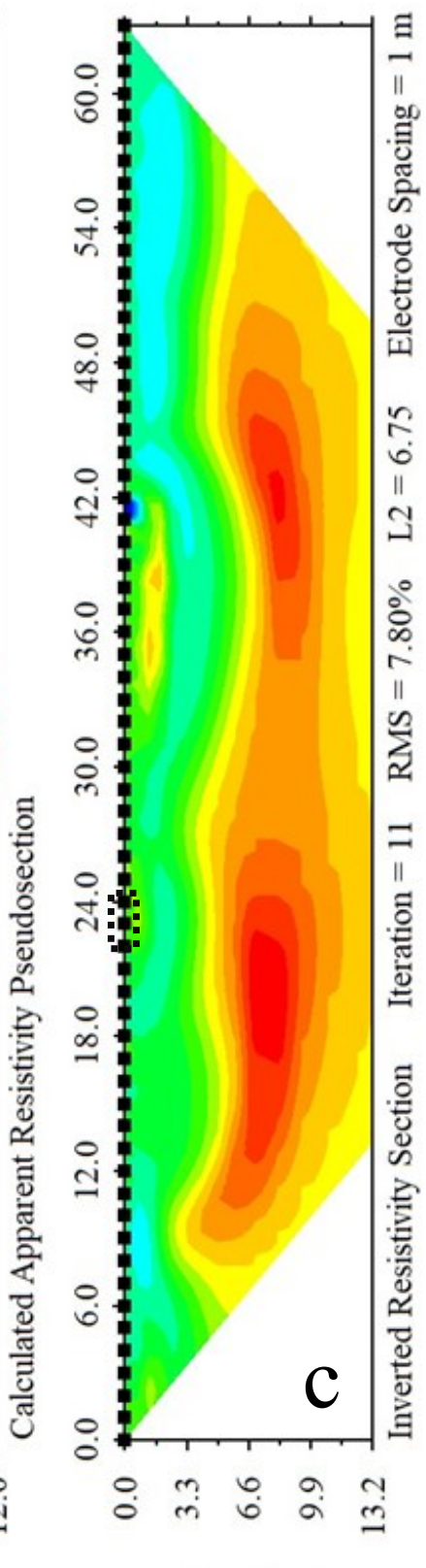

(ui) पрdәС

Figure 15. a) The collected geophysical data from survey line RR b. b) The calculated model of the collected data. c) The final model produced from the calculated model. The tufa deposit location is depicted by small dashed box. The RMS value for the survey is $7.80 \%$. 


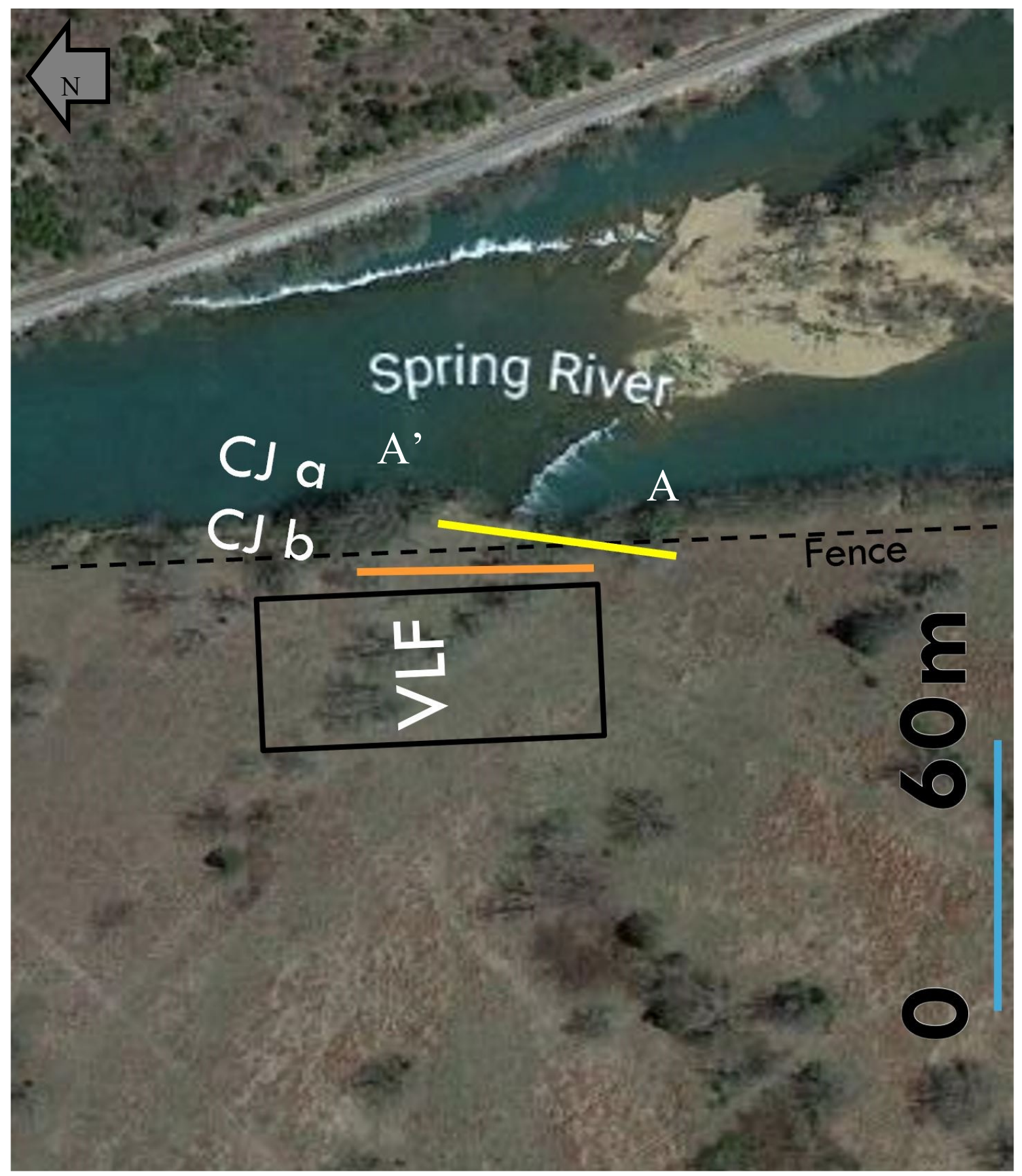

Figure 16. Satellite image showing the location of the third geophysical site at Circle J Farms $(\mathrm{CJ} \mathrm{a}$ and $\mathrm{CJ} \mathrm{b})$. The two surveys are shown parallel to the river and are perpendicular to the tufa deposit. $\mathrm{CJ}$ a is closer to the river and shown by the yellow line. CJ b is further away from the river shown by the orange line. The letters A and A' correspond to the letters in Figure 18 and 19. The black box is the area covered by the VLF-EM survey. 


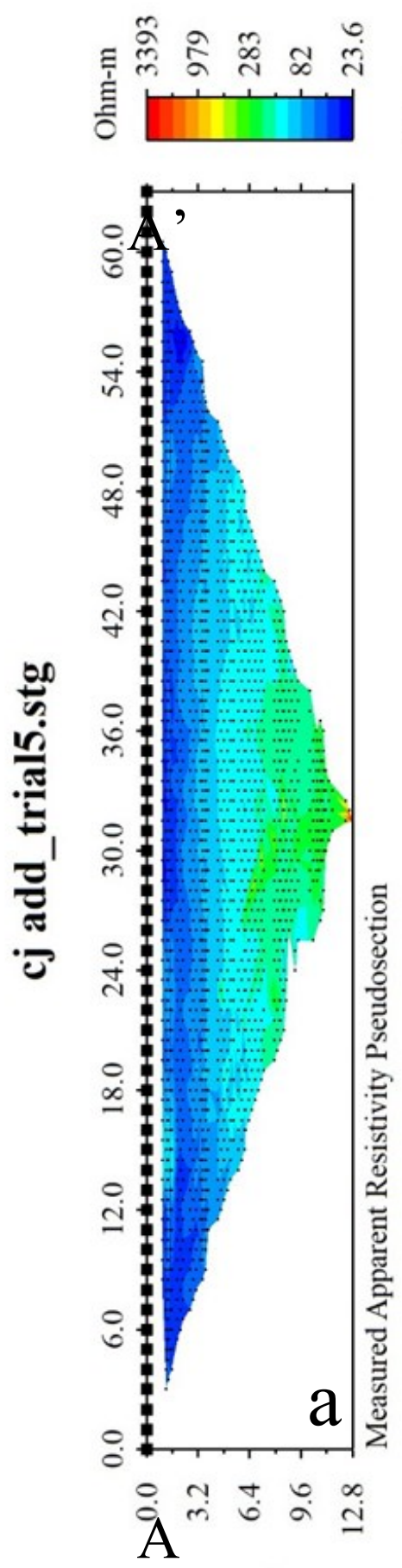

(ui) पıdəC
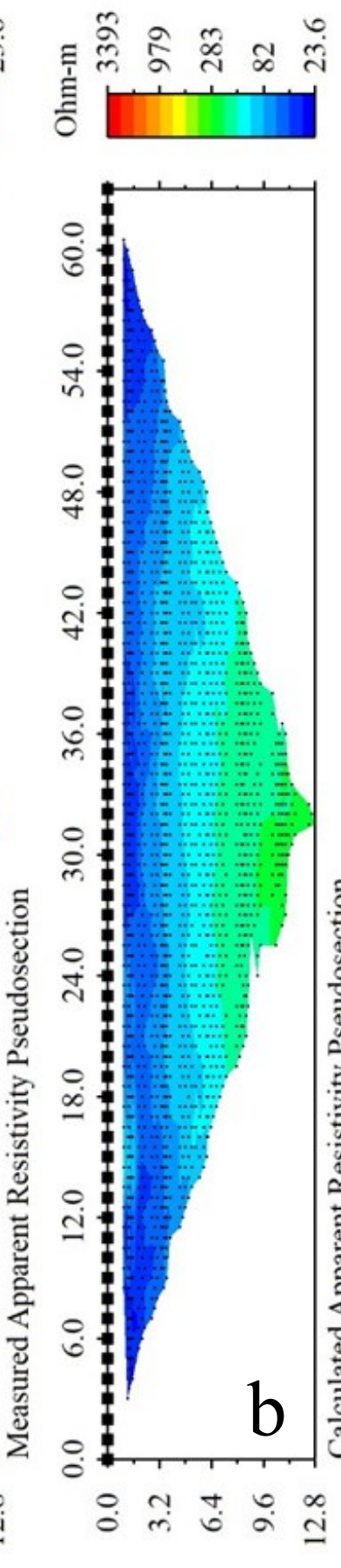

(uI) प1อव
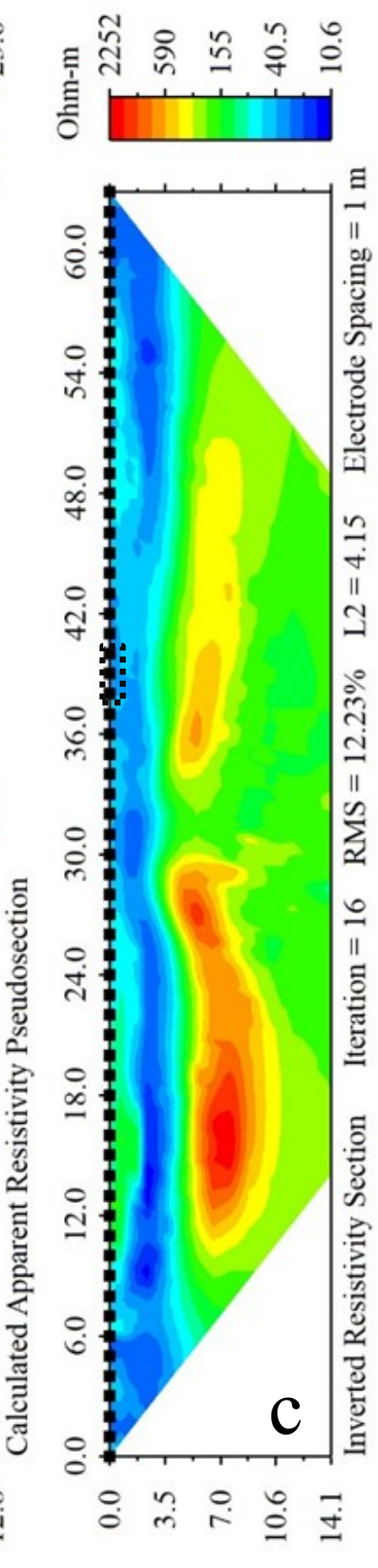

(ய) प1ग्व

Figure 17. a) The collected geophysical data from survey line CJ a. b) The calculated model of the collected data. c) The final model produced from the calculated model. The tufa deposit location is depicted by a small dashed box. The RMS value for the survey is high at $12.23 \%$. 


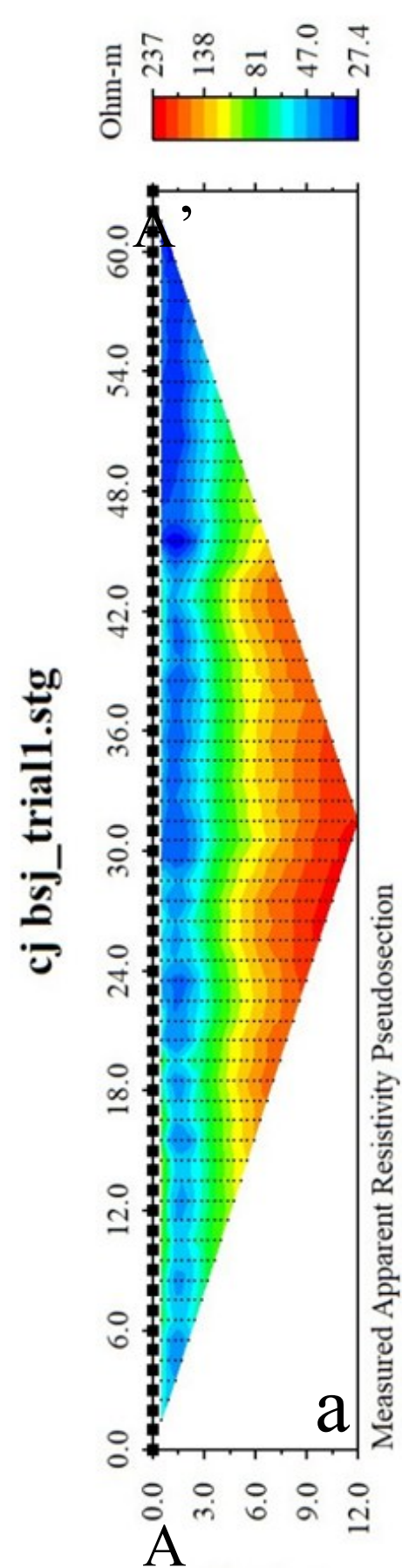

(III) чрवә्व

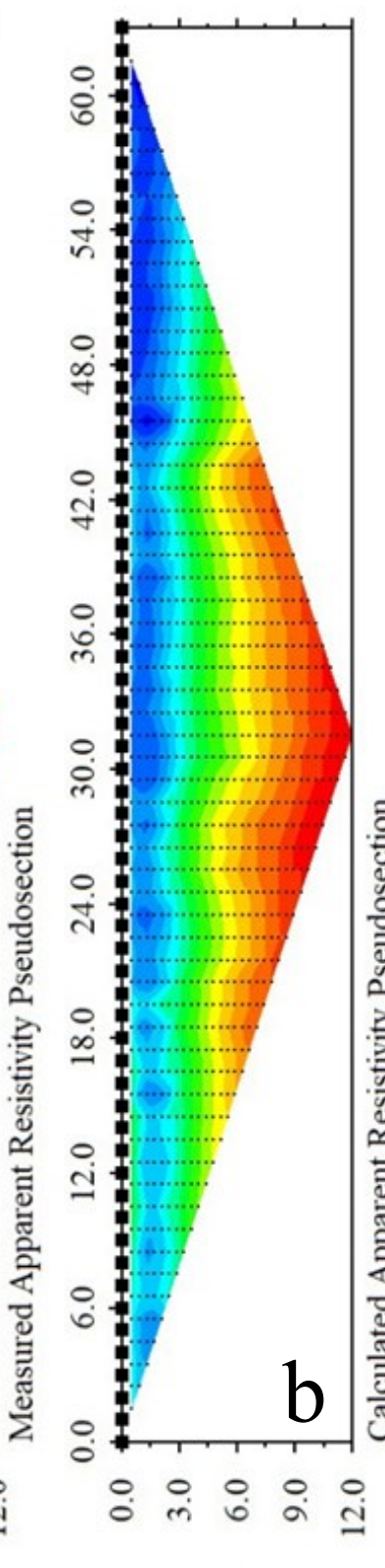

(uI) पागә्व
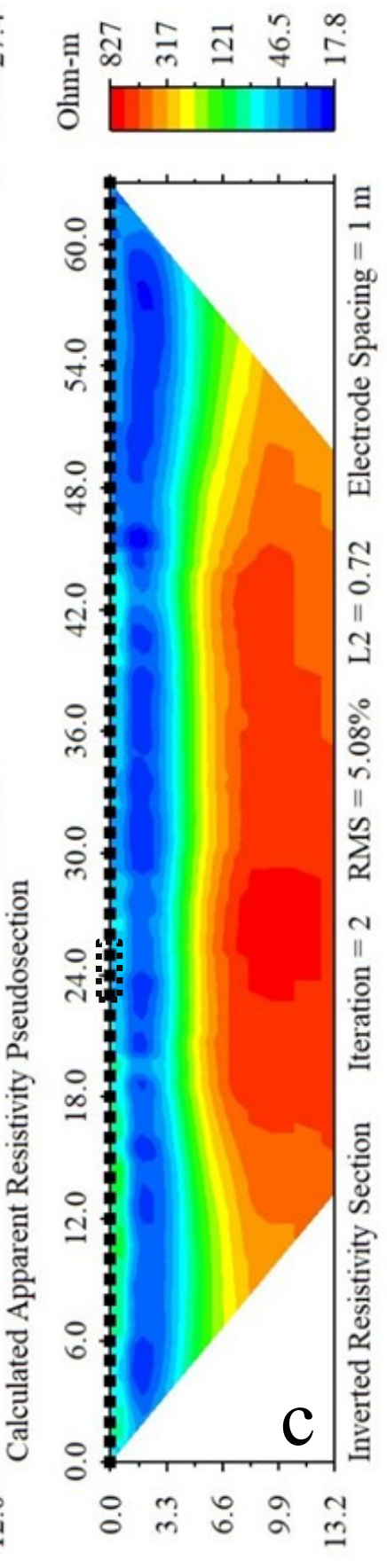

(ui) ч1.ә्व

Figure 18. a) The collected geophysical data from survey line $\mathrm{CJ}$ b. b) The calculated model of the collected data. c) The final model produced from the calculated model. The tufa deposit location is depicted by a small dashed box. The RMS value for the survey is $5.08 \%$. 

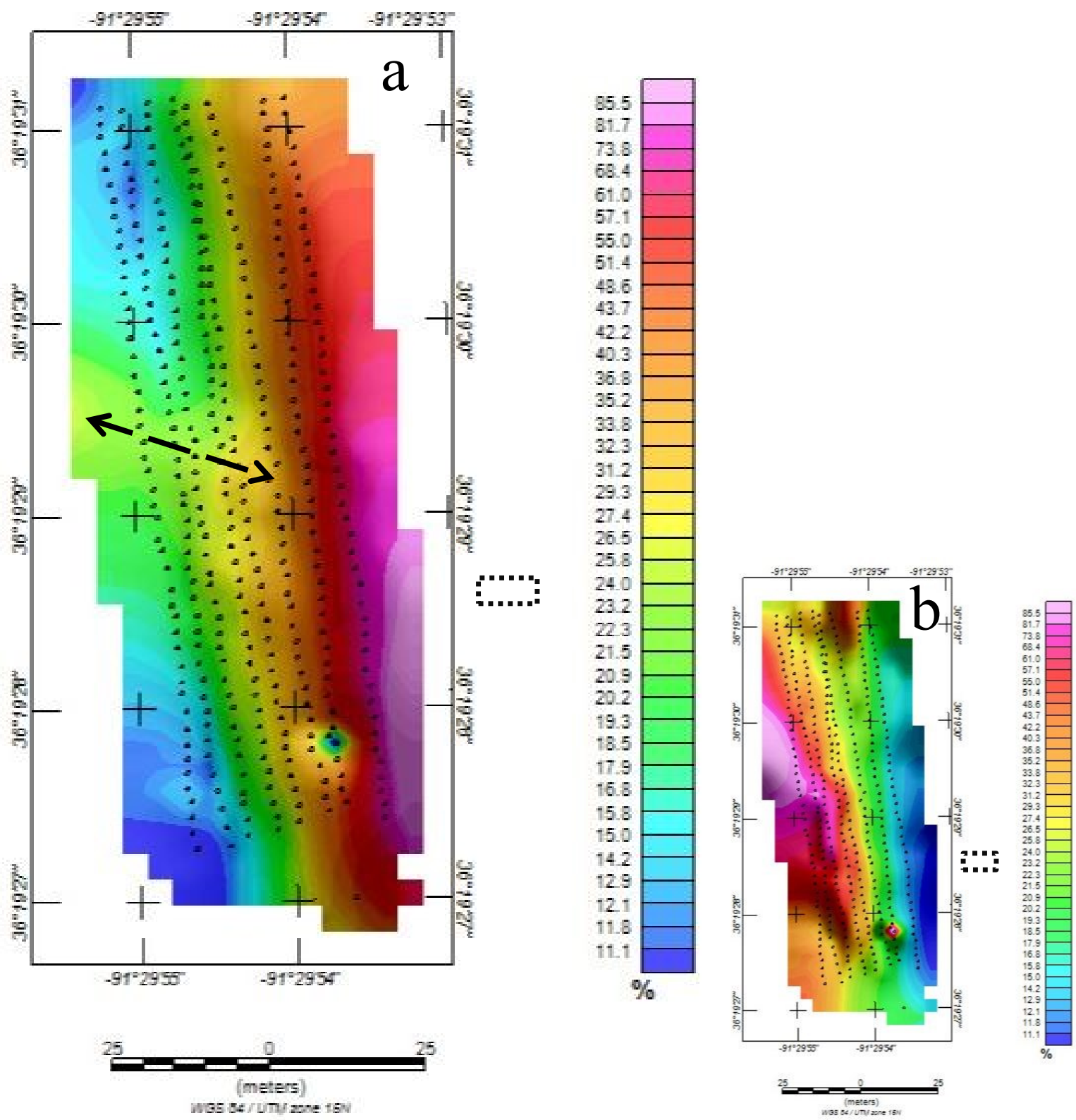

Figure 19. a) Color image of the IP data produced by the VLF-EM. b) Color image of the OP data produced by the VLF-EM. Both were taken on the same frequency of $24.6 \mathrm{KHz}$ broadcasted from the station in North Dakota. The two-sided arrow is showing the linear feature seen in the IP data. The small dashed box is showing the location of the tufa with respect to the survey. The small black dots that go throughout both IP and OP are the location where data points were collected with the VLF-EM. 


\section{Coring}

Coring was done at three locations, two of which were the same locations as the geophysics studies. The first location that was cored was at Riverside Resort Camp and Canoe (RR) and was one of the locations where a geophysical study was conducted. Four cores were taken from the RR location and the cores came from different locations on the deposit. The hole depth versus the core recovery was different for each core hole. The deepest core hole at RR was 40 inches (1.02 meters) in depth. A summary of all the coring depths is shown in Table 1.

The second location was roughly two miles downriver at Saddler Falls (SS). Geophysics was not conducted at this location because there was not enough room on the riverbank due to houses and streambank stabilization materials. Only one core was taken at this location. The core hole was 45.5 inches (1.16 meters) in depth.

The third location was at Circle J Farms (CJ), where geophysics had been conducted as

well. At this location, three cores were taken from two different deposits that were separated by a sand bar in the middle of the river. The deepest core hole at this location was 110 inches $(2.79$ meters) in depth. An example photo of core is provided in Figure 20, photos of all other core recovered are provided in Appendix D. 
Table 1. The core hole depth versus core recovery for RR, SS, and CJ.

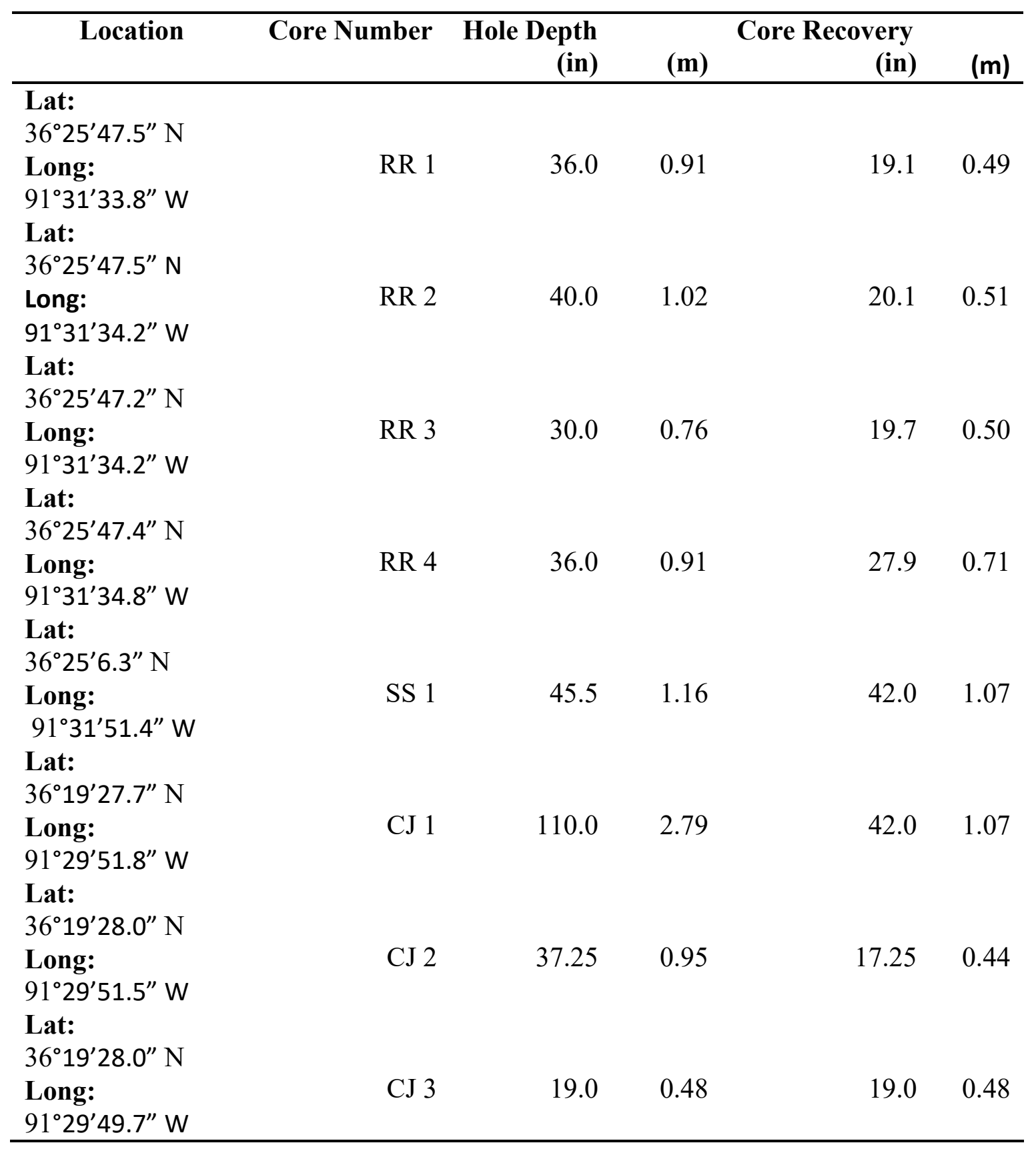




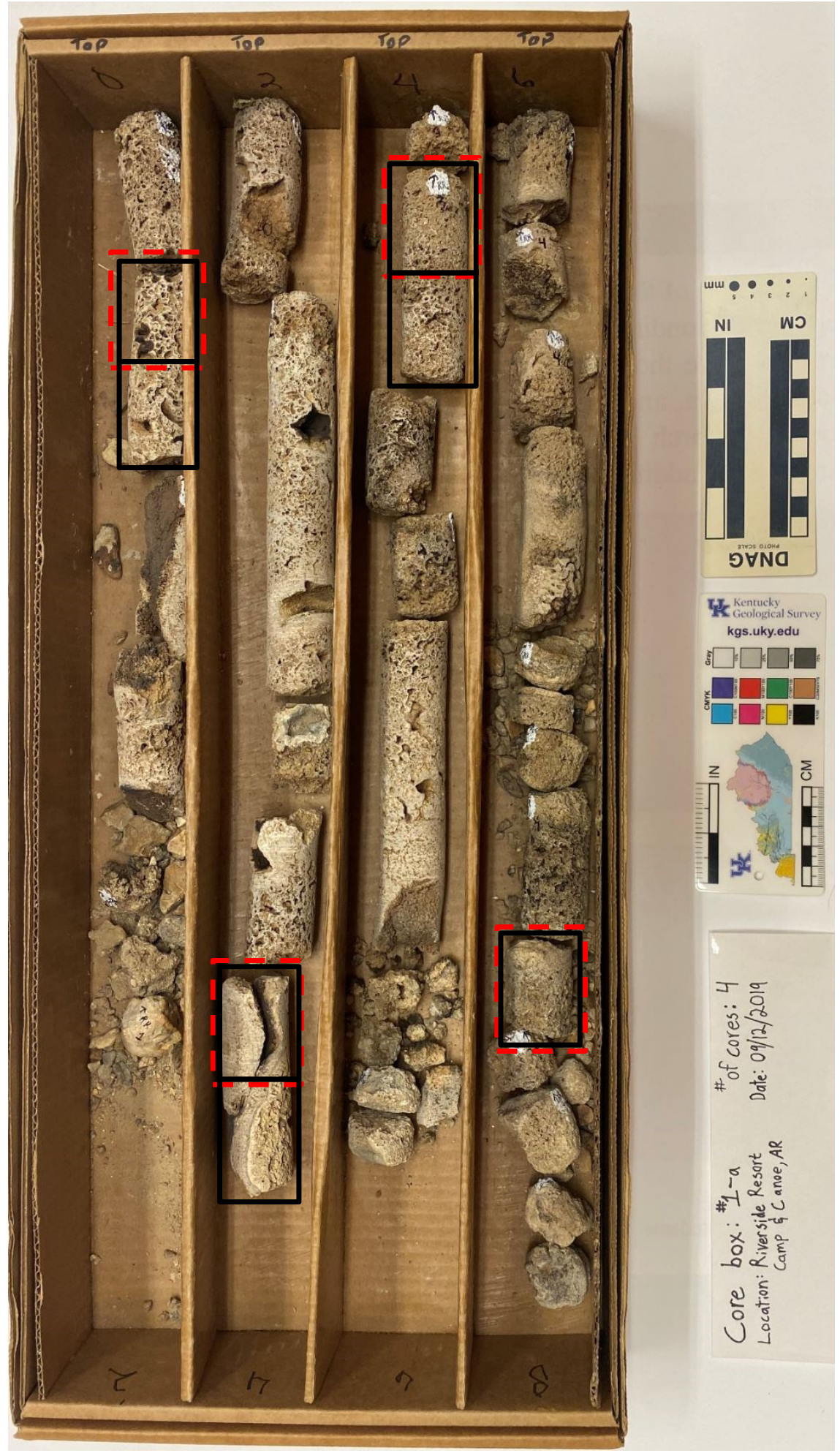

Figure 20. Core that was collected from Riverside Resort Camp and Canoe (Four cores). It starts with RR1 on the left and then to RR4 on the right. This is the core that thin section and SEM samples were taken from. The black boxes show which samples were used for thin sections and the red dashed boxes show the samples used for the SEM. 


\section{Thin Section and SEM Data}

Thin sections were made from the core from the Riverside Resort Camp and Canoe (Figure 21). A total of seven thin sections were made from these four cores. All seven of the thin sections display a similar structure. There appear to be layered growth patterns in the structure as seen in plain polarizing light (ppl). In the crossed polarized light (xpl), a secondary calcite growth is seen on the edges of the structure near the pore spaces.

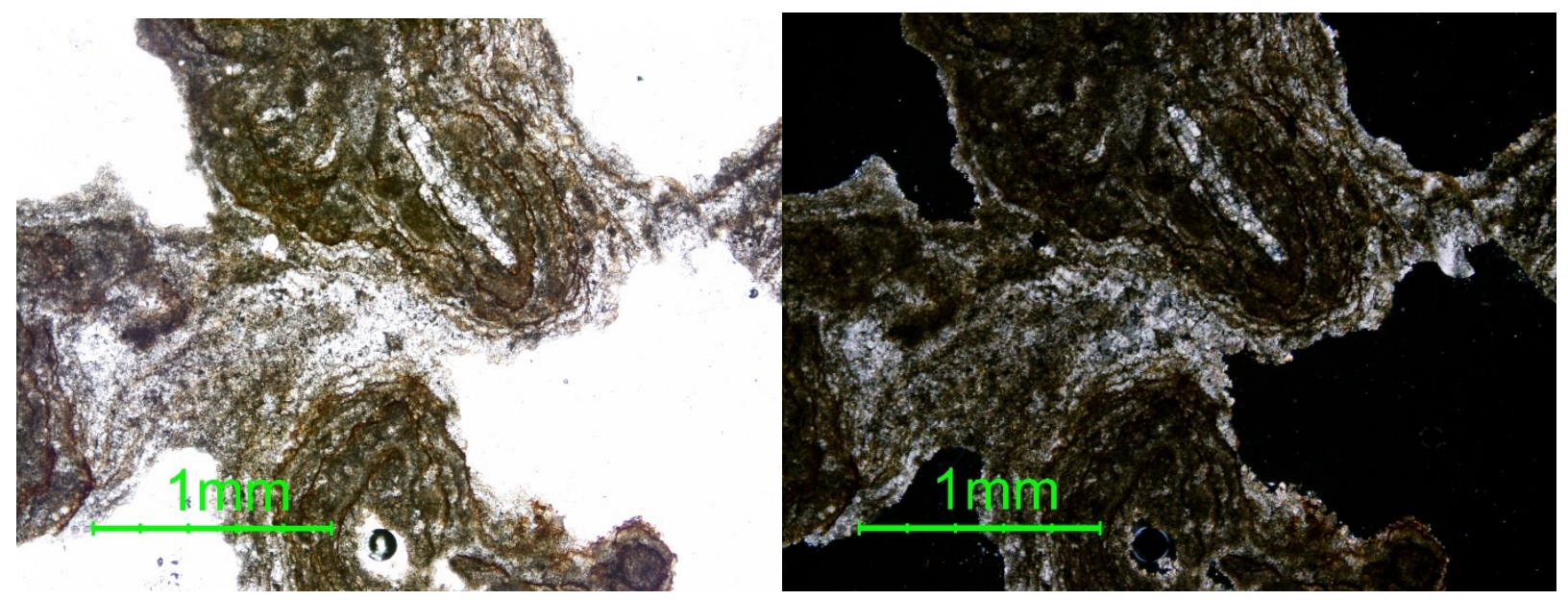

Figure 21. Thin Sections made from Core RR1, sample two, and top portion. The left is in plain polarizing light and the right is in crossed polarized light.

SEM analysis of the tufa deposits was performed to look at microstructures. In the SEM images, filaments can be seen (Figure 22). The images in Figure 22 are from a macropore space which is seen through all SEM samples. The filaments in Figure 23 have interwoven themselves with other filaments inside the micropore space of the tufa, which is seen throughout all samples. In the macropore space of the tufa, it has a layered pore space where as the micropore space have a smooth pore space wall. 


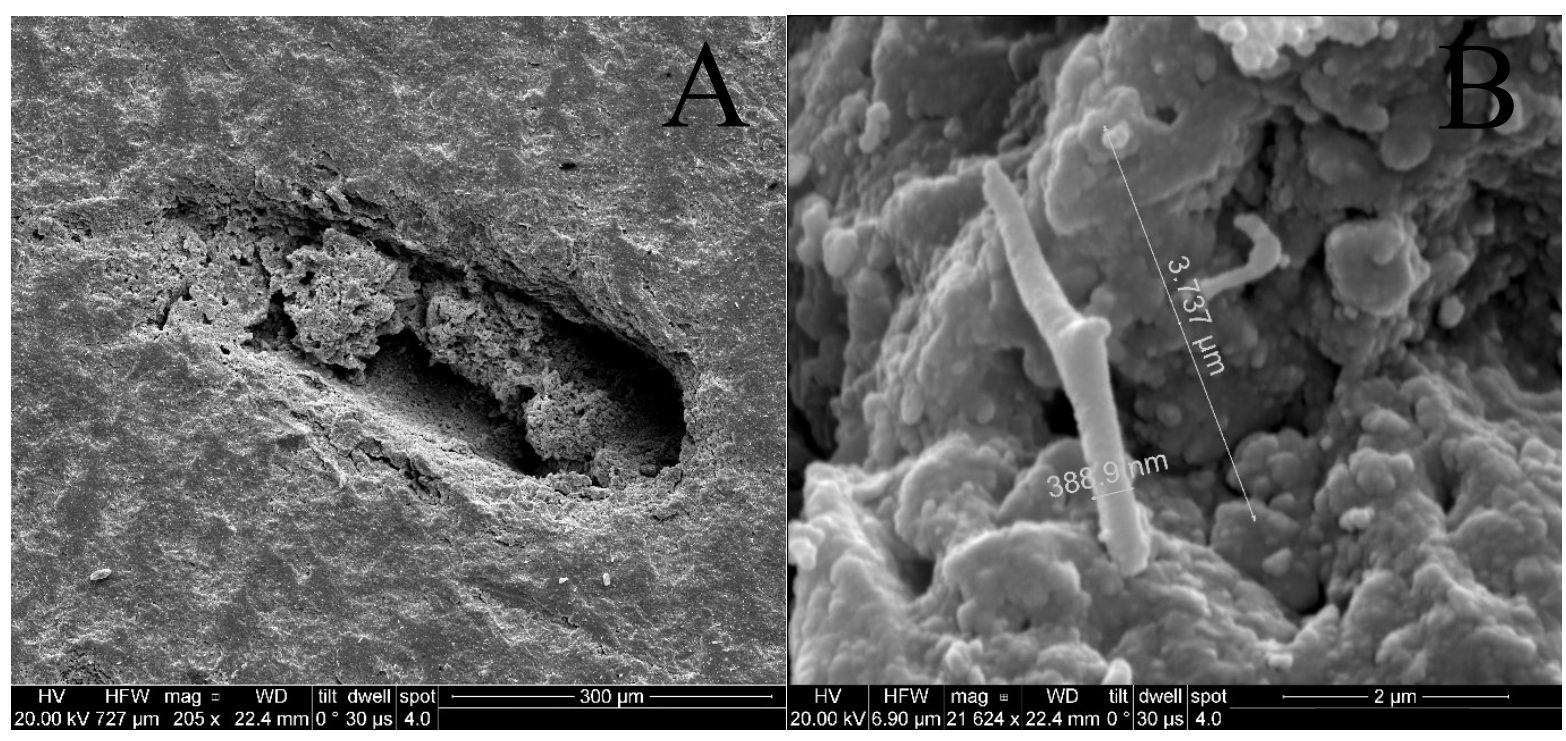

Figure 22. A) SEM image from Core, RR 1, sample two, and top portion. In this image a macropore of the tufa is shown and can be seen with naked eye also. B) A close up of a filament inside the macropore. The filament has a branched section, and a layered pore wall.
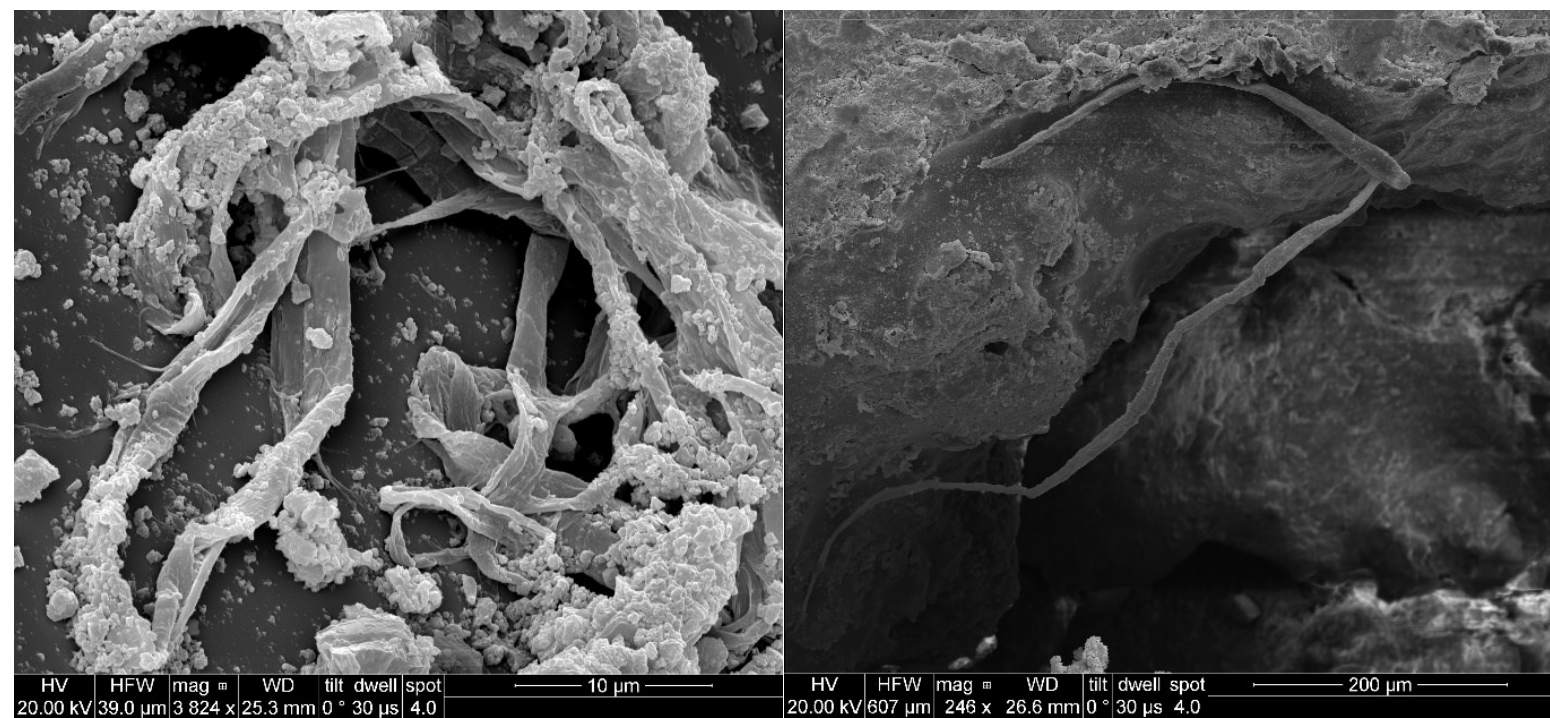

Figure 23. SEM image from Core RR 2 (left), sample five, and core RR 3 (Right), sample two. The left image is from a micropore space showing interwoven filaments. The right image is from a macropore space showing longer filaments that are branched. 


\section{DISCUSSION}

\section{Structure Analysis}

The data collected for the tufa has been compared to other studies around Arkansas and in southern Missouri. The data shown on the Missouri Geological Survey Geosciences Technical Resource Assessment Tool (GeoStrat) is mostly located within the state, but some features extend into surrounding states. When analyzing the geologic structures mapped on GeoStrat, some data extends into northern Arkansas near Mammoth Spring. With the GeoStrat data, there is a northeast to southwest joint trend at roughly $050^{\circ}-060^{\circ}$ and a northwest to southeast trend at roughly $350^{\circ}-360^{\circ}$. The data in GeoStrat is comparable to the data from this study on the general trend of the tufa.

Orndorff et al. (2002) performed a study comparing cave passages to the trends of joints in Southern Missouri. In this paper, a rose diagram was created, and the major orientations of the joints were $070^{\circ}-080^{\circ}$ and $350^{\circ}-360^{\circ}$ (Figure 24 ).
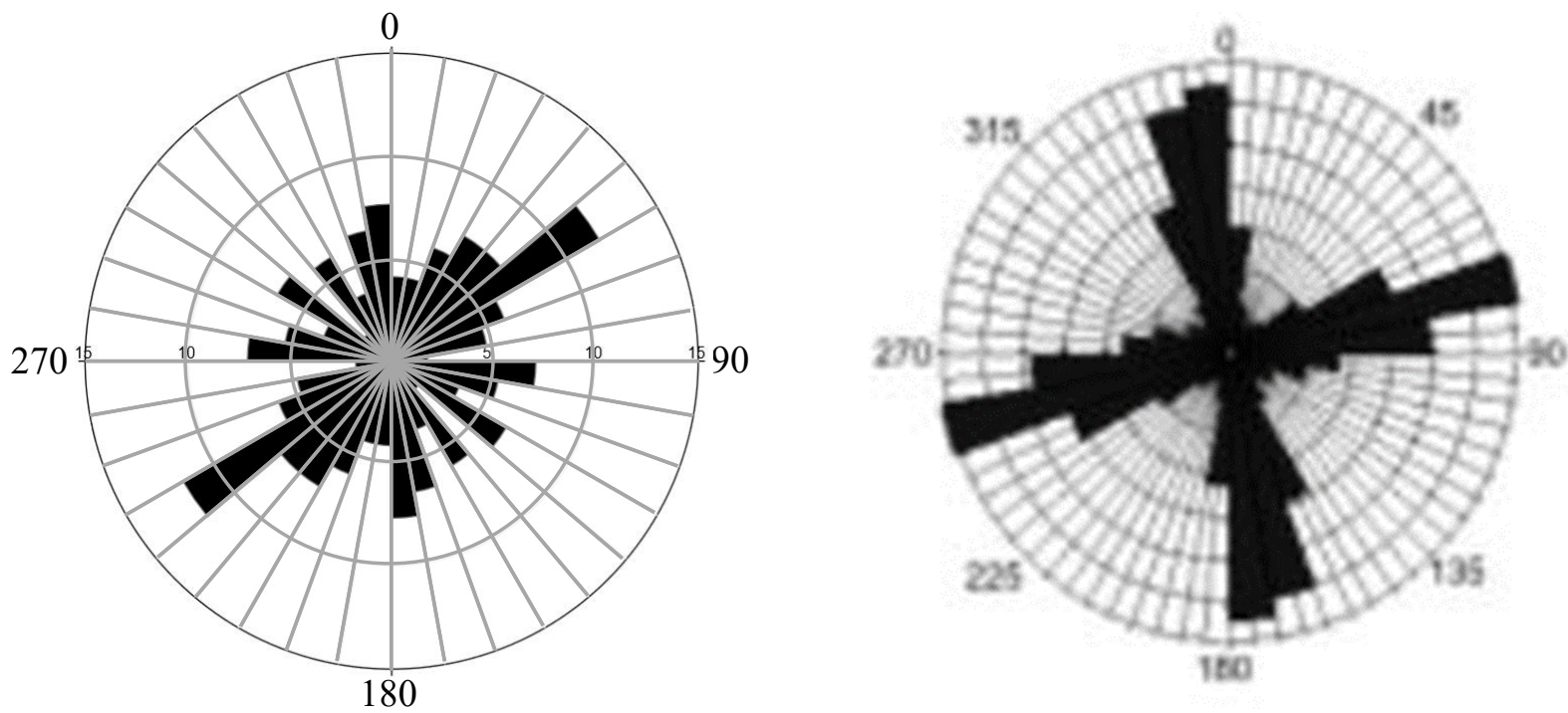

Figure 24. Diagram on the right are joints trends in southern Missouri (Orndorff et al., 2002), from 5,285 mapped structure orientations. The rose diagram on the left is the data from this study with 168 data points. North is at the top $\left(0^{\circ}\right)$. 
When the Orndorff et al. (2002) data is compared to the general trend of the tufa there is a similar north to south orientation. The northeast to southwest trend has a twenty-degree difference. The tufa major trend is from $050^{\circ}-060^{\circ}$ and Orndorff's major trend is $070^{\circ}-080^{\circ}$.

Prior (2020), collected data on fractures and joints in the Mammoth Spring, AR quadrangle in a preliminary mapping project. These data show a major trend in the north to south direction at $000^{\circ}-010^{\circ}$ and another major trend in the east to west direction at $080^{\circ}-100^{\circ}$. The tufa major trends of $050^{\circ}-060^{\circ}$ and $350^{\circ}-360^{\circ}$ do not correlate with structures mapped by Prior (2020) as seen in Figure 25.
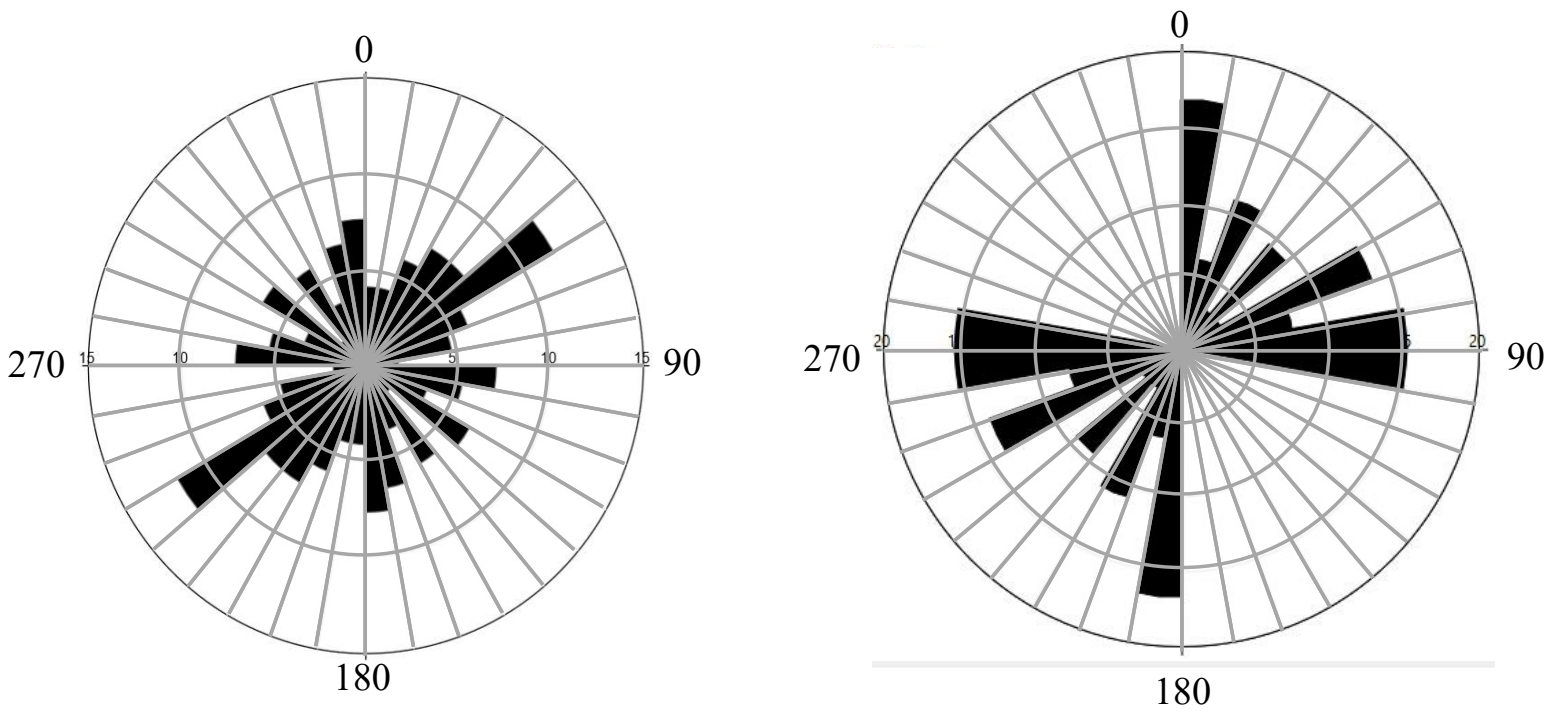

Figure 25. Diagram to the left is the general trend of the tufa with 168 data points. The diagram on the right is data from Prior (2020) with 66 data points. North is at the top $\left(0^{\circ}\right)$.

Orndorff et al. (2002) data was mapped around Branson, MO on joint sets in relationship to cave passages. Prior (2020) mapped data around the study area in outcrops, quarries, and creeks around the Spring River. For this study, the data was measured in the river on the trends of the tufa. When comparing all three of the rose diagrams they do not match with the largest major trend. Orndorff et al. (2002) data lines up closer to the tufa trends then the data from Prior (2020). 


\section{Geophysical Analysis}

Geophysics was used to help find if a structural control would occur in the river that helped to deposit the tufa. In geophysical surveys the difference between the layers in the subsurface is denoted by certain colors. A high resistance material in the area would be a dolomite and a low resistance material would be considered the topsoil. The geophysical surveys that were collected on the riverbank it showed a high resistance under the tufa and off to the sides are a point of lower resistance anomaly (Figure 26). In Figure 26 the dashed box on the right-hand side of the survey was a location of known rock at the surface. The thin dashed line depicts where the topsoil layer would be located and is seen as the dark blue color. This dark blue color is the lowest resistance value. The tufa has a high resistance anomaly located underneath it. This anomaly is too deep to be the tufa, considering the elevation at which the survey was conducted compared to the depth of the bank and depth of water to the tufa. The difference is about half a meter. The depth of the anomaly is close to two meters. This anomaly is interpreted to be Cotter and Jefferson City dolomite underneath the tufa.

In Figure 26 the profile has two low resistance anomalies (in green) separating what is interpreted to be Cotter and Jeff City dolomite. These two anomalies are marked by thick black line. These two anomalies are interpreted to be fractures in the rock. The interpreted fracture on the right side of the tufa is upstream of the deposit and the one to the left is downstream of the deposit. There was no tufa seen within five to ten meter after the interpreted fracture downstream from the tufa deposit marked in the survey (Figure 26). 


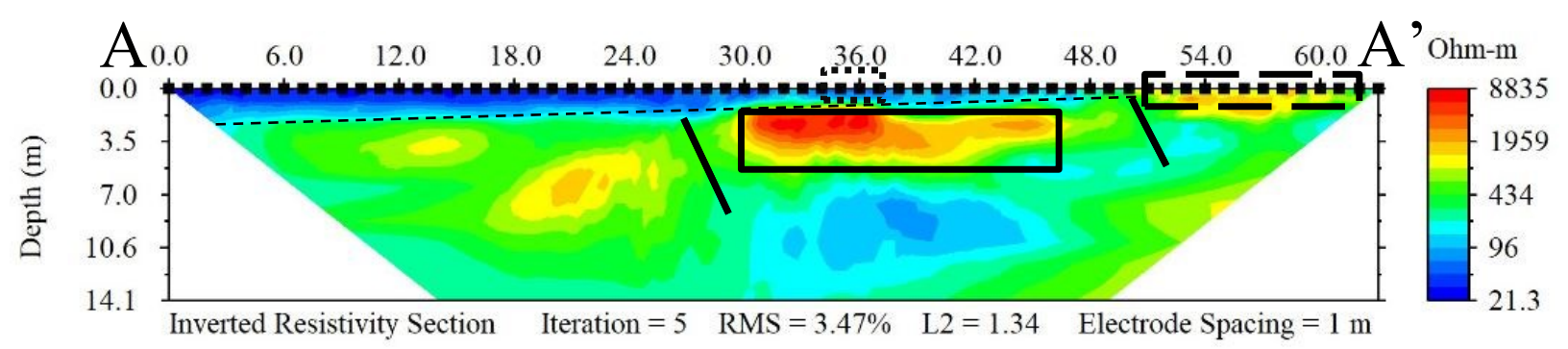

Figure 26. Interpreted geophysical model of survey Jen-b that was five meters from the water's edge. The second profile is better than the first profile due to the lower noise in the survey. The tufa was breaking the water surface in the river at electrode 36 . The dashed box to the right side of the survey was exposed rock at the surface. The water is flowing from right to left.

Figure 27 is the model from Riverside Resort Camp and Canoe. As seen in the model from Jen-b, the tufa has a high-resistance anomaly underneath it. Profile RR-a has the lowest noise affecting the survey which gives a better reading. The high resistance anomalies are being interpreted as the Cotter and Jeff City dolomite and the low resistive anomalies separating the high resistive anomalies are interpreted to be fractures in the rock. As was the case at Jen-a, there was no tufa seen within five to ten meters downstream from the fracture after the tufa marked in the survey (Figure 27).

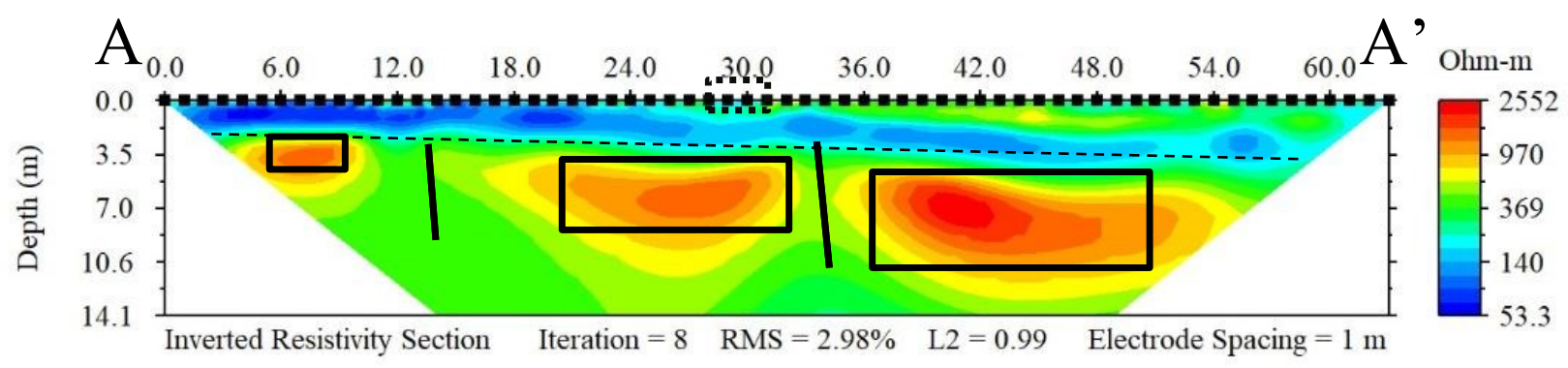

Figure 27. Interpreted geophysical model of survey RR-a and was about two meters from the water's edge. This was the first survey conducted at this location and it shows three high resistance anomalies. The water is flowing from right to left.

Figure 28 is from Circle J Farms near the downstream end of the study area. This profile exhibits similarities from the previous two profiles through the study area. The resistance anomaly underneath the tufa is not as strongly resistive as the two previous locations, but that is partially due to the smoothing of the profile considering the higher noise value. The high 
resistance anomalies are interpreted to be Cotter and Jeff City dolomite and the lower resistance anomalies are interpreted to be fractures in the rock. At this location only one fracture can be interpreted, and it is downstream from the tufa deposit marked on the survey (Figure 28).

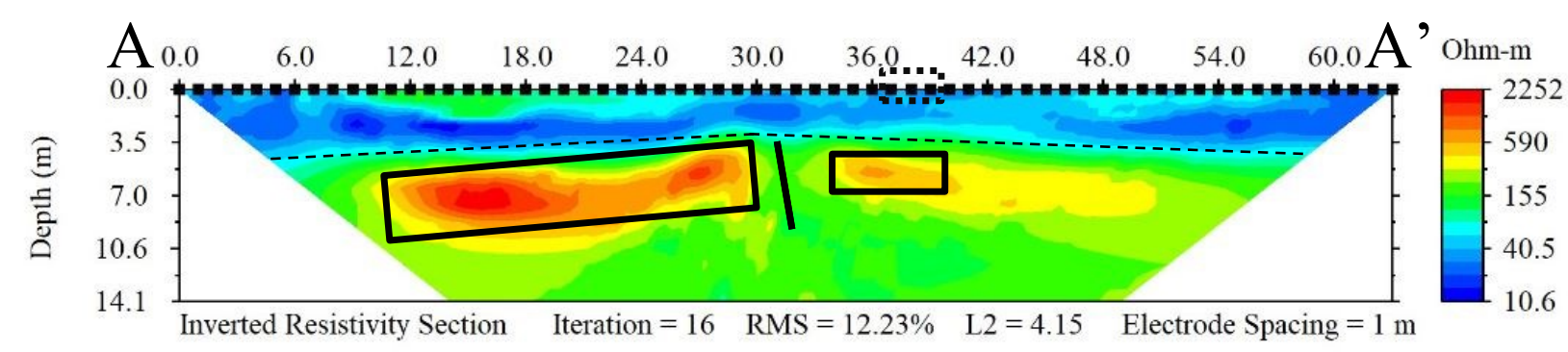

Figure 28. Interperted geophysical model of survey CJ-a and was about two meters from the water's edge. This was the first survey conducted at this location. At electrode seven a fence was over the top of the line and from electrode 12 to 16 there was an erosional surface creating a swag in the line. The water is flowing from right to left.

With all three of the locations where geophysical surveys were conducted only one tufa deposit could be seen at the surface of the water in the river. Each survey only had one deposit in the profile and the final model did not show the tufa under the riverbank. The profiles also showed one to two spots which were interpreted as fractures in the rock. When comparing the first two locations, a fracture upstream and downstream of the tufa deposit can be seen in the geophysics. At CJ the third location only one fracture in interpreted to be downstream of the deposit. For all three locations the deposit could be seen breaking the surface of the water and the interpreted fractures seen in the geophysics were not seen at the surface. The geophysics profiles display fractures buried underneath a low resistive layer, which is interpreted as top soil due to the surveys being conducted in the flood plain of the river.

The joint sets in the study area mapped by Prior (2020) have North to South and East to West dominant trends. The tufa deposits have a dominant Northeast to Southwest trend which is different than Prior (2020). The tufa deposits do not appear follow a pattern with deposition locations. Some locations have several tufa deposits while other locations have one tufa deposit. 
The tufa deposits in the study area exhibit constant changes in growth patterns and interval continuity.

Using aerial analysis, mapping data from Prior (2020), and geophysics allowed for better understanding on the locational controls of tufa deposits. Since aerial analysis and preliminary mapping data do not match up, this suggests that the primary control of tufa deposition is not structurally dominated. However, interpretations from the geophysical data shows fractures located around the deposits, which are not exposed at the surface. It can be interpreted that the

tufa is not structurally controlled, but there does appear to be some influence from the structures since four of the six surveys consisted of multiple fractures. The influence of fractures could provide a conduit for the mixing of groundwater with surface water, which could aid in the growth/deposition of tufa at a site(s) in the river. Brogi et al. (2012) suggest that the location of tufa deposits could be affected by the geometry of faults and their related minor structures.

\section{Core Analysis}

Core samples were taken from tufa deposits in the river to better understand their vertical extent and to see if there was a vertical change in the structure of the deposit. These core samples were taken in several locations throughout the length of the study area to see if there was a change in the deposits farther downstream from the mouth of Mammoth Spring. The deposits closer to the spring were thinner than those farther downriver, which were thicker. The first location cored was at Riverside Resort Camp and Canoe (RR). The deepest core hole there was 1.02 meters in depth. RR location is about six miles downriver from the spring. The second location was Saddlers Falls (SS) and the core hole depth was 1.16 meters. SS is about eight 
miles downriver from the spring. The third location was Circle J Farms (CJ) and the core hole depth was 2.79 meters in depth. CJ is about seventeen miles downriver from the spring.

Field measurements show that there is a noticeable difference in the size of each dam and length of the shelf leading to each dam. The tufa deposits closer to Mammoth Spring have a smaller overall size shelf and dam than those downstream (Figure 29). Downstream tufa deposits are a little deeper in the water column and have a larger shelf and dam (Figure 30). The core hole depth was used to see the vertical extent of the deposits. The cores taken from the different deposits through the study area do not show any significant change in the tufa properties. The photography analysis on the core samples analyzing porosity also does not show a significant change in the deposits from the top to the bottom of the core (on the samples larger enough to analyze). When evaluating all of the cores there is not a significant change in the overall porosity from samples taken closer to the spring and those taken further downstream.

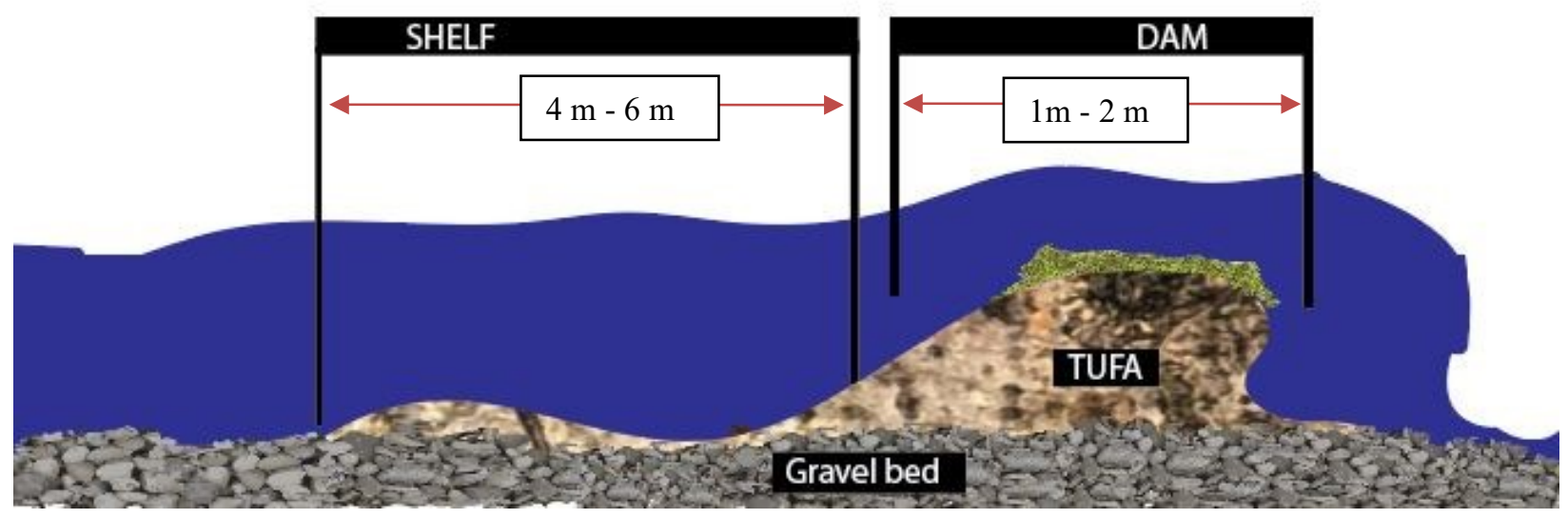

Figure 29. Schematic cross-section of the coring location from Riverside Resort Camp and Canoe (RR). The water is flowing from left to right over the shelf and the dam. The green material represents moss/algae on the dam. 


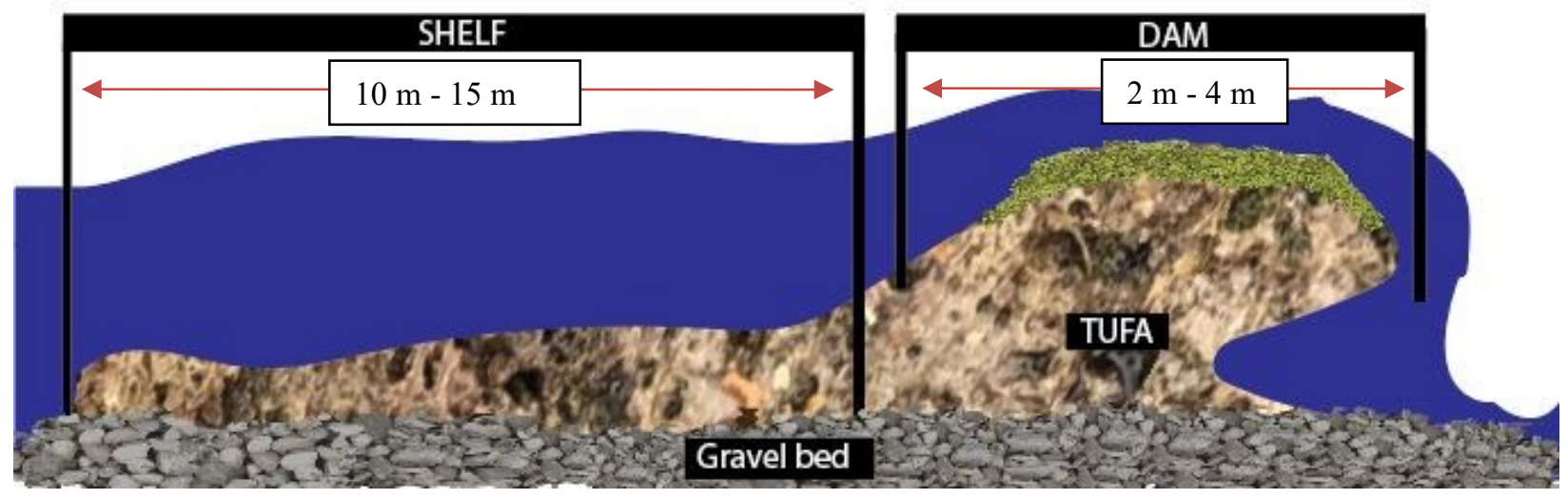

Figure 30. Schematic of the coring location at Circle J Farms (CJ). The deposit at this location has a larger shelf and dam compared to RR. The water is flowing from left to right over the shelf and dam portion on the deposit.

Cores do not show a direct correlation between the thickness of the tufa and the high resistive anomalies underneath the tufa. At site RR, resistivity measurements indicate an anomaly underneath the tufa, but the depth to the anomaly was about 3 meters and cores show the tufa thickness was only 1.16 meters deep. Resistivity measurements at CJ showed an anomaly underneath the tufa that was about 4 meters deep and cores showed the tufa thickness was only 2.79 meters deep. The resistive anomaly is therefore assumed to be Cotter and Jeff City dolomite surface, rather than the base of the tufa, which is above the sediment surface. Since no tufa deposits were identified under the riverbanks, it is interpreted that the deposits are relatively young, younger than the existing river meanders.

The thickness distribution in the deposits could be the result of depositional rates or that some are older than others. Given that tufa deposits are thicker downstream on average it can be interpreted that they are either older or have factors causing faster depositional rates. Faster depositional rates could be related to a greater volume of water entering the river system through surrounding tributaries. A different explanation of why the deposits further downstream are thicker than the ones upstream is that they are older and experienced longer periods of 
precipitation. Assuming the deposits downstream are older, this could be an explanation as to why there is a slight increase in porosity downstream (Avg. 2-8\% difference). More exposure to moving water relates to greater dissolution throughout the deposit.

\section{Microscopic Analysis}

Tufa samples were thin sectioned and imaged using an SEM to determine whether or not the facies discussed in Rainey and Jones (2007) were present (Figure 31). When comparing the tufa deposits in the Spring River to Rainey and Jones (2007), a similar structure in the thin sections can be seen but the SEM images are not similar (Figure 32). Rainey and Jones (2007) had micrite imbedded in their samples that helped to identify a change in the season of deposition. Rainey and Jones (2007) also looked at pieces of wood that were imbedded in the tufa samples which allowed them to get an age date on the wood that was $350+/-50$ years. This allowed for a general age date on the tufa at the time the wood was encapsulated into the tufa. In the Spring River tufa neither micrite nor wood was observed in the tufa deposits. 


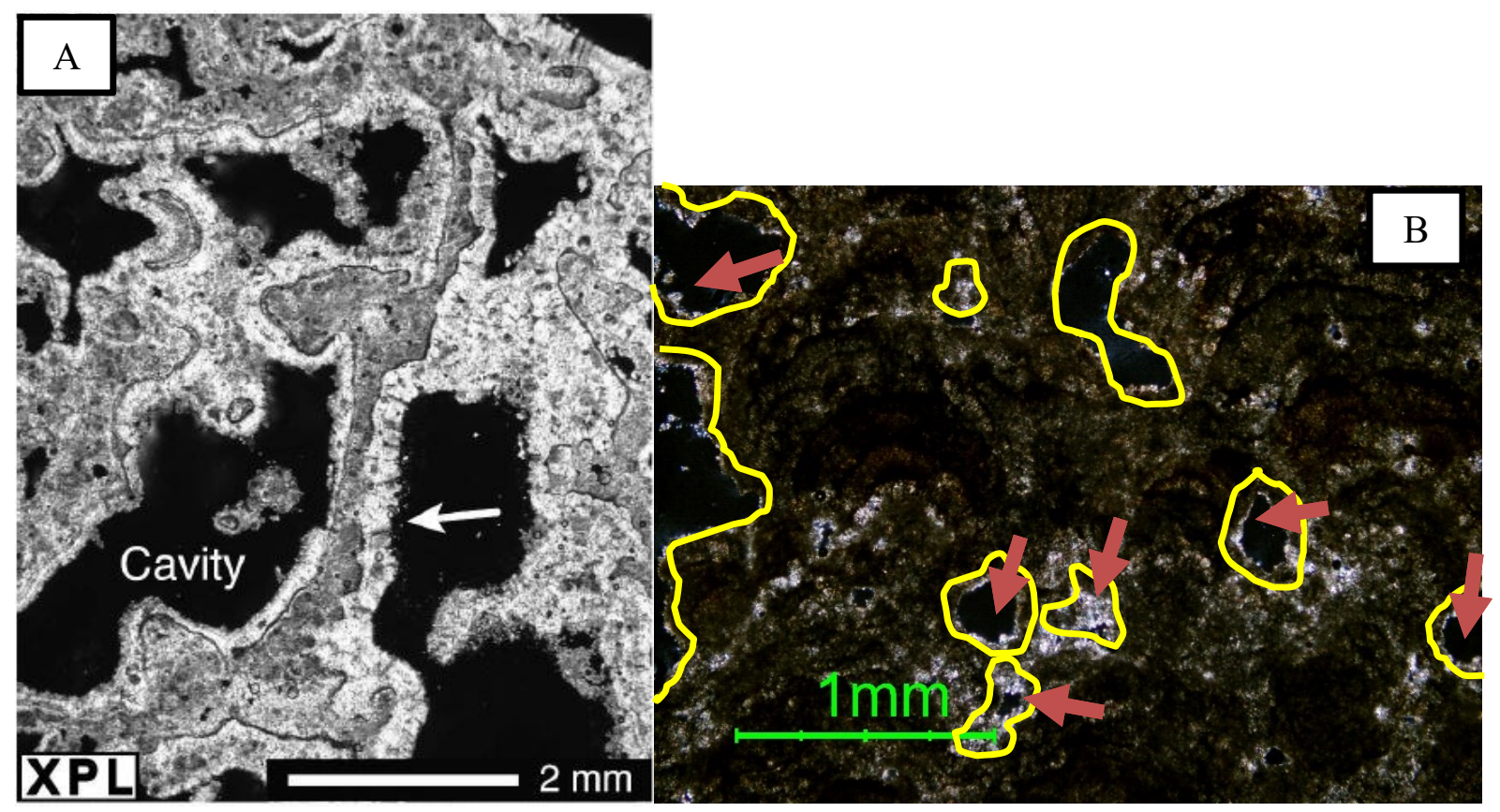

Figure 31. A) Thin section in cross polar light (xpl) showing where the cavities are in the tufa and the white arrow points out the significant secondary calcite growth on the tufa. B) A thin section from the tufa in the Spring River in xpl. The yellow polygons are drawn around the cavities in the thin section. The pink arrows are pointing out where secondary calcite growth can be seen.
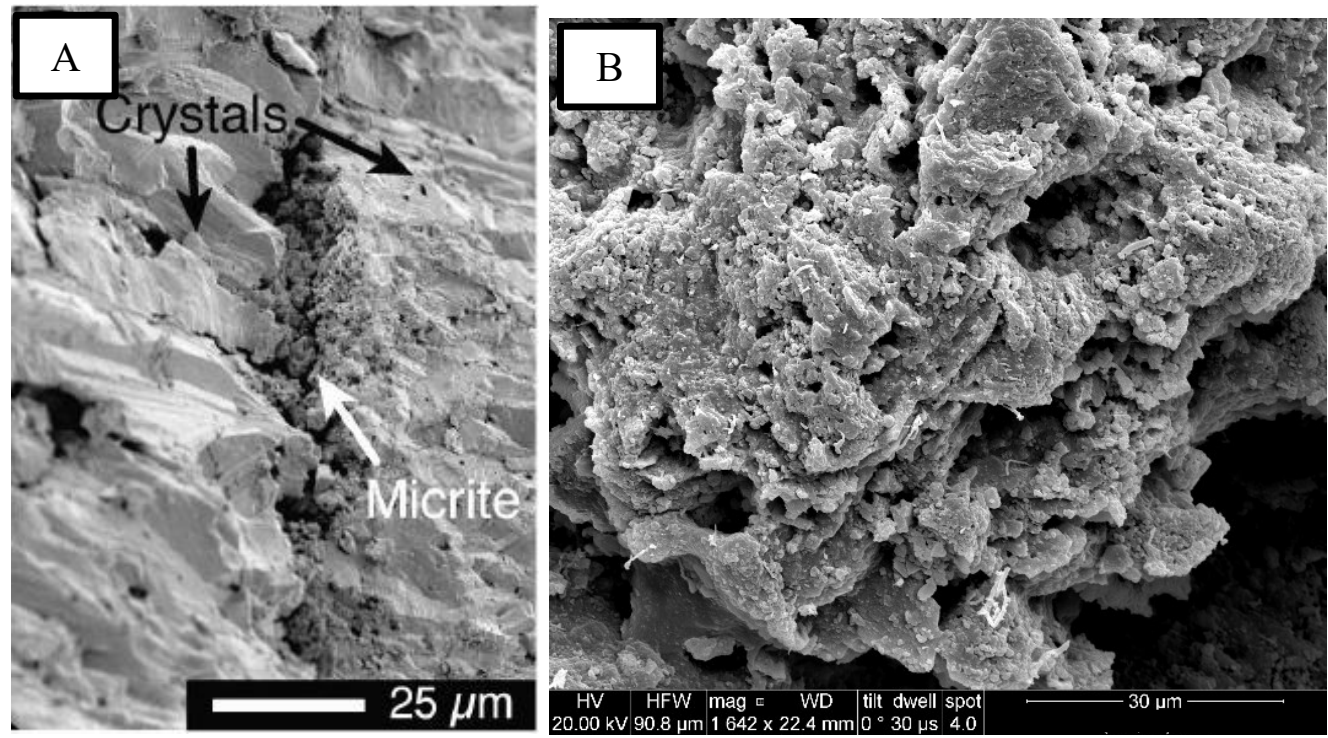

Figure 32. A) SEM image from Rainey and Jones (2007). This SEM image is showing the calcite crystals they found in their tufa and micrite imbedded within the tufa. This tufa also has more pronounced crystals. B) An SEM image from the tufa in the Spring River. It has more of a layered structure and has less of a crystalized structure. It does not have full mosaic crystals as seen in Rainey and Jones (2007). 
In Rainey and Jones, (2007), a series of facies changes are discussed. Four different stages are shown during tufa development. The first stage was encrustation, involving the precipitation of calcite crystals. Stage two is encapsulation, as calcite crystals grow together and around one another to form a new crust. Stage three is cavity occlusion, which results from cement precipitation or mechanical sedimentation in the cavities of the tufa. Stage four is diagenetic modification, which is the formation of new crystals considered to be mosaic calcite. When looking at the Spring River tufa stage one and stage two can be seen in all the thin sections. The thin section in crossed polar light (xpl) show the start of secondary calcite growth within the pore spaces, which suggests the deposit might have started into stage three (Figure 31). Electron microscope micrographs show calcite growth in the pore spaces, which can be seen in every sample. All the textures in thin sections and SEM micrographs show a biogenic growth structure. These textures and structures are commonly found in tufa deposits (Rainey and Jones 2007; Capezzouli et al., 2014).

Core samples contain native and non-native mollusks (Barnhart, 2020). Two species of native bivalves are present: Sphaeriidae (fingernail clams) and Pleurocera acuta (gastropod). Both native species are found in situ within the core samples (Figure 33). The two native bivalves in the sample have been found in the area dating back to the last ice age (Barnhart, 2020). Although the biota does not give an exact age, the deposits are potentially as old as the late Pleistocene (last ice age). However, since these particular bivalves and mollusks are present in the system today, the deposits could also be as young as present time (Trauth et al., 2007). 


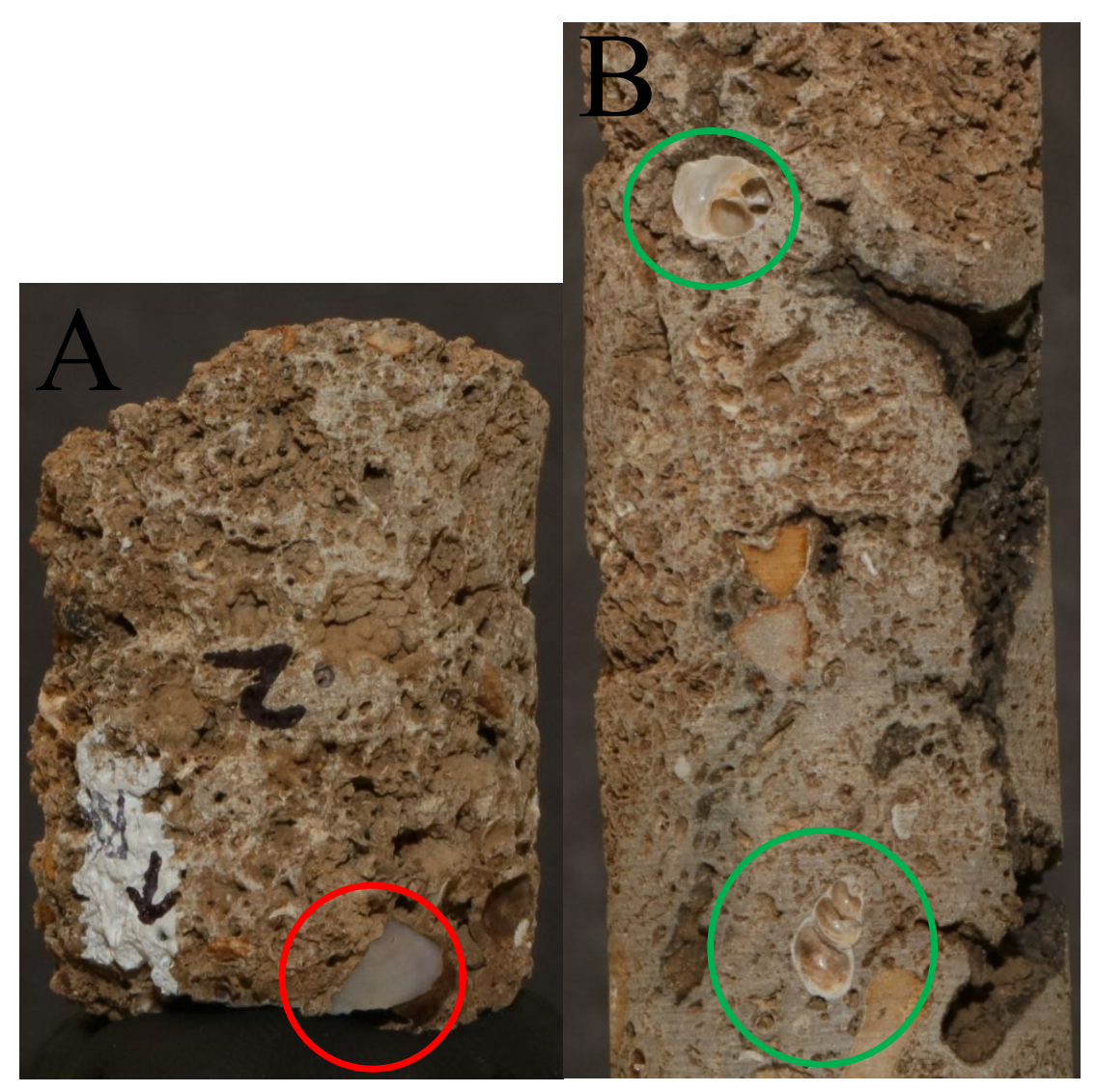

Figure 33. A) Core sample from RR in the second core hole. The red circle is the location of the Sphaeriidae seen in place on the sample. The white mark on the core denotes the top of the sample. B) This is a part of a core sample from SS. The two green circles are where the Pleurocera acuta are found in the core sample.

The non-native species Corbicula fluminea (Asian clam) was recovered from the sand near the bottom of the core hole (Barnhart, 2020). These clams were introduced into the environment around the 1930's. The law of superposition states that in an undeformed sequence of sedimentary rocks, each bed is older than the one above it and younger than the one below it. Assuming the strata is undisturbed the tufa deposit is younger than the clams found in the core sample. Due to the sand below the tufa deposit being in an unconsolidated state, it is possible that the tufa predated the sand and clams that were found underneath. When looking at the core box of CJ 1, the non-native species is found after run one in unconsolidated sand along with broken pieces of tufa. The broke tufa could be due to the water undercutting the dam at higher 
rates of flow, along with debris which could've broken off pieces of tufa depositing them with soft sediments (Figure 34). These soft sediments can easily be moved and then redeposited

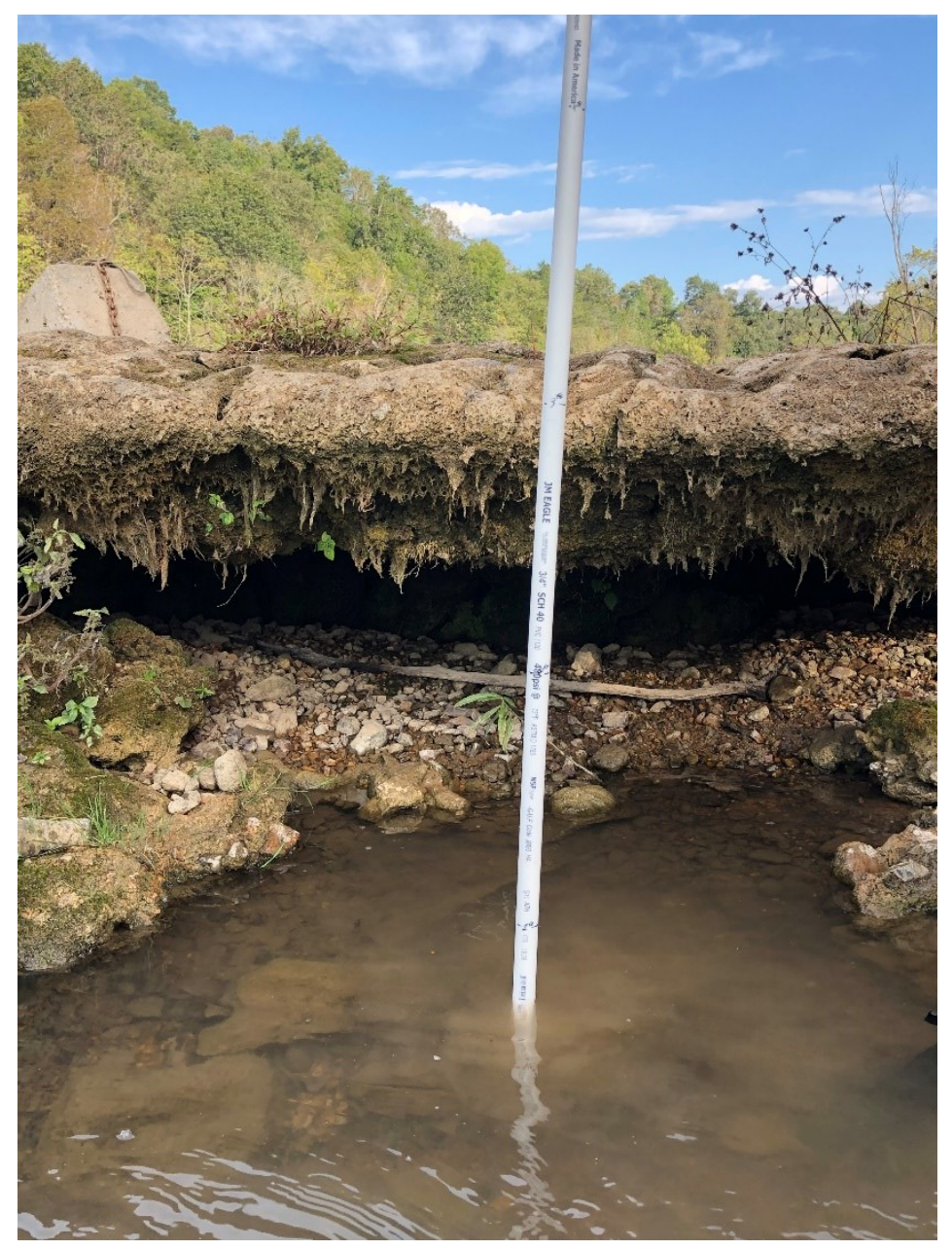

Figure 34. Tufa deposit exhibiting undercutting and deposition of younger material. The marking on the pipe are measurements in feet.

depending on the amount of discharge the river exhibits throughout the year. When taking the core, there was a noticeable drop between the bottom of the tufa (run 1) and the loose sand and clam shells (run 2). This gap signifies an unconformity between the tufa and the unconsolidated sand (CJ 1-Appendix C and D). Runs 2 and 3 consisted entirely of present-day river alluvium. Run 4 for CJ 1 resulted in unrecoverable sample recovery. After detailed of the analysis of the 
core sample there were no non-native species found in situ. From these observations it can be interpreted that the tufa existed prior to the introduction of the non-native clams in the 1930's.

\section{General Discussion}

One of the first research questions for this project was if the tufa had a structural control on the deposition location. The aerial imagery analysis along with the preliminary mapping data from Prior (2020) and geophysics was used to help answer this question.

The aerial analysis and mapping data do not match one another. The major trend from the tufa is between the two major trends in the Prior (2020) data (Figure 25). This suggests that structural control is not a dominate influence on the deposits. However, since many of the geophysical surveys showed fractures upstream and downstream of the deposits, it is interpreted that these structures may have played a minor role in tufa formation.

The second research question asked how old these deposits are. If these deposits were older than the preexisting river channel they would have been found to be buried under the riverbank in a meander of the river. For this, geophysics was used to see if the deposits extended underneath the banks of the river in the meanders.

The three locations that had geophysical surveys conducted were spread out through the study area. The six survey profiles conducted showed a high resistive anomaly anywhere from three meters deep to five meters deep. After comparing geophysics to coring the high resistive anomalies were interpreted to be Cotter and Jeff City dolomite. The geophysics did not show the tufa to extend underneath the river banks.

Coring was used to get an understanding of the vertical extent of the deposits that were closer to the mouth of the spring, than the ones further away. The coring was used in the 
interpretation of the geophysical surveys. Core samples showed a thickening of the deposits down river, which might suggest that the deposits down river are older than the ones closer to the mouth of the spring. Taken together, the cores and the geophysics indicate that the high resistive anomalies are much deeper than the tufa. This indicates, the tufa does not extend underneath the riverbanks and the tufa is younger than the meanders of the river.

Based on a study done by Rainey and Jones (2007), the core thin sections and SEM photos indicate that the tufa in this study are in the start of their stage three (cavity occlusion which is the growth of secondary calcite in the pore spaces). This shows that it has not gone through the full cycle reported by Rainey and Jones (2007). In their study Rainey and Jones reported a piece of wood that was incapsulated in their tufa to be $350+/-50$ years old. In the Spring River tufa deposits the only datable element found in situ were native mollusks that have been present to the area since the Late Pleistocene to present. 


\section{CONCLUSION}

Imagery analysis along with mapping data from Arkansas Geologic Survey gave an idea of features that interact with the Spring River. The features that were mapped were joints and fractures in surrounding outcrops located in the Mammoth Spring Quadrangle. With the preliminary mapping data provided by Prior (2020) a rose diagram was created along with the rose diagram from the trends of the tufa. When comparing the two diagrams of the mapped joints and of the trends on the tufa it can be seen that the predominant trends do not line up. The geophysics suggest that some of the deposits could have a structural influence but are probably not completely controlled by these features.

With the data that was collected from geophysics and coring a relative age on the tufa can be determined. The geophysical surveys do not show the tufa underneath the river bank. There is a high resistive anomaly under the riverbank where the tufa is located in the river. With further analysis and data from coring of the tufa in the river it can be seen that the tufa is not thick enough to correlate to the depth at which the resistive anomaly is located. Therefore, the tufa deposits are interpreted to be younger than the preexisting river channel.

The microscopic analysis shows that the tufa has a biogenic growth pattern. In the thin sections, secondary calcite growth (apparently inorganic) can be seen coating a mounded growth pattern similar to that of a stromatolite. These samples have features similar to those found in other studies conducted on tufa. The comparison shows that the tufa here is relatively young and related to biogenic growth. 


\section{Future Research}

Additional coring needs to be undertaken on the riverbanks in line with the tufa to see if the deposits extend under the riverbank. This will help to better understand what the current geophysical surveys have shown and aid in finding the depth to the Cotter and Jeff City dolomite in this area. More coring data can then be compared to the previous surveys and see if the geophysics is correct that the tufa is not under the riverbanks. A second coring study on the tufa deposits in the river would be useful to potentially locate in place shells in the dam that could possibly give a better age date on the tufa deposits.

More geophysical surveys should then be performed at several more locations to see if the final models vary at any point downriver next to the deposits. Profiles should also be conducted in locations where the tufa is absent to see if similar results are found. If there is a significant change in the profiles it could give better insight to controls on the tufa deposition. With additional surveys and cores along the river bank a better understanding of the vertical extent and lateral extent of the tufa can also be determined.

Temperature data could be collected along the deposits to see if a change is occurring up stream or downstream of the deposits that would influence deposition at these locations. With this a geochemical analysis of the water should be conducted at several of the dams to see if a change occurs before and/or after the dams. This will help to determine why there are so many more structures farther from the mouth of the spring rather than closer to it.

The South Fork Spring River also should be investigated with similar measures, because from aerial imagery analysis that shows it to have a few structures similar to those on the Spring River, and might also be tufa deposits. These are the only two rivers in this watershed that 
contain structures like this, so a comparison could isolate common characteristics responsible for the tufa deposition. 


\section{REFERENCES CITED}

Allmendinger, R., 2006, A computer program for stereonets, http://www.geo.cornell.edu/geology/faculty/RWA/programs/stereonet.html.

Altunel, E., and Hancock, P.L., 1996, Structural attributes of travertine-filled extensional fissures in the Pamukkale Plateau, Western Turkey: International Geology Review, v. 38, p. 768777, doi:10.1080/00206819709465360.

Barnhart, C., 2020, personal communication, Missouri State University, 901 S. National Ave. Springfield, MO 65897 (January 2020).

Bhuiyan, C., 2015, Hydrological characterisation of geological lineaments: a case study from the Aravalli terrain, India: Hydrogeology Journal, v. 23, p. 673-686, doi:10.1007/s10040015-1239-0.

Brogi, A., Capezzuoli, E., Buracchi, E., and Branca, M., 2012, Tectonic control on travertine and calcareous tufa deposition in a low-temperature geothermal system (Sarteano, Central Italy): Journal of the Geological Society, v. 169, p. 461-476, doi:10.1144/001676492011-137.

Capezzuoli, E., Gandin, A., and Pedley, M., 2014, Decoding tufa and travertine (fresh water carbonates) in the sedimentary record: the state of the art: Sedimentology, v. 61, p. 1-21, doi:10.1111/sed.12075.

Crossey, L.J., Fischer, T.P., Patchett, P.J., Karlstrom, K.E., Hilton, D.R., Newell, D.L., Huntoon, P., Reynolds, A.C., and de Leeuw, G.A.M., 2006, Dissected hydrologic system at the Grand Canyon: Interaction between deeply derived fluids and plateau aquifer waters in modern springs and travertine: Geology, v. 34, p. 25-28, doi:10.1130/G22057.1.

De Filippis, L., Faccenna, C., Billi, A., Anzalone, E., Brilli, M., Özkul, M., Soligo, M., Tuccimei, P., and Villa, I.M., 2012, Growth of fi ssure ridge travertines from geothermal springs of Denizli Basin, western Turkey: Bulletin of the Geological Society of America, v. 124, p. 1629-1645, doi:10.1130/B30606.1.

Evans, J.E., 1999, Recognition and implications of Eocene tufas and travertines in the Chadron formation, White River Group, Badlands of South Dakota: Sedimentology, v. 46, p. 771789, doi:10.1046/j.1365-3091.1999.00250.x.

Ford, T.D., and Pedley, H.M., 1996, A review of tufa and travertine deposits of the world: EarthScience Reviews, v. 41, p. 117-175, doi:10.1016/S0012-8252(96)00030-X.

Hancock, P.L., Chalmers, R.M.L., Altunel, E., and Cakir, Z., 1999, Travitonics: using travertines in active fault studies: Journal of Structural Geology, v. 21, p. 903-916, doi:S01918141(99)00061-9. 
Jacobson, R.L., and Langmuir, D., 1974, Controls on the quality variations of some carbonate spring waters: Journal of Hydrology, v. 23, p. 247-265, doi:10.1016/00221694(74)90006-7.

Kano, A., Matsuoka, J., Kojo, T., and Fujii, H., 2003, Origin of annual laminations in tufa deposits, southwest Japan: Palaeogeography, Palaeoclimatology, Palaeoecology, v. 191, p. 243-262, doi:10.1016/0031-0182(02)00717-4.

Kawai, T., Kano, A., Matsuoka, J., and Ihara, T., 2006, Seasonal variation in water chemistry and depositional processes in a tufa-bearing stream in SW-Japan, based on 5 years of monthly observations: Chemical Geology, v. 232, p. 33-53, doi:10.1016/j.chemgeo.2006.02.011.

Luhmann, A.J., Covington, M.D., Peters, A.J., Alexander, S.C., Anger, C.T., Green, J.A., Runkel, A.C., and Alexander, E.C., 2011, Classification of Thermal Patterns at Karst Springs and Cave Streams: Ground Water, v. 49, p. 324-335, doi:10.1111/j.17456584.2010.00737.x.

Manzo, E., Perri, E., and Tucker, M.E., 2012, Carbonate deposition in a fluvial tufa system: processes and products (Corvino Valley-southern Italy): Sedimentology, v. 59, p. 553577, doi:10.1111/j.1365-3091.2011.01266.x.

McFarland, J.D., 2004, Stratigraphic Summary of Arkansas: Arkansas Geological Survey Information Circular, v. 36, p. 44, http://www.geology.ar.gov/info_circulars/ic36.htm.

National Weather Service, 2018, Climatological Report Little Rock, AR: Electronic document, available at http://ww.ncdc.noaa.gov (accessed March 2019).

Orndorff, R.C., Weary, D.J., and Sebela, S., 2002, Geologic framework of the Ozarks of southcentral Missouri; contributions to a conceptual model of karst: Missouri speleology, v. 42, p. $1-8$.

Owen, R.B., Renaut, R.W. and Stamatakis, M.G. 2010, Diatomaceous sedimentation in late Neogene lacustrine basins of western Macedonia. Greece. J. Paleolimnol., v. 44, p. 343359, doi:10.1007/s10933-010-9409-5.

Pedley, H.M., 1990, Classification and environmental models of cool freshwater tufas: Sedimentary Geology, v. 68, p. 143-154, doi:10.1016.0037-0738(90)90124-C.

Prior, B., 2020, personal communication, Arkansas Geological Survey, 3815 W Roosevelt Rd, Little Rock, AR 72204 (February 2020).

Rainey, D.K., and Jones, B., 2007, Rapid cold water formation and recrystallization of relict bryophyte tufa at the Fall Creek cold springs, Alberta, Canada: v. 909, p. 889-909, doi:10.1139/E07-008. 
Rasband, Wayne, 2019, Imagej is a Java-based image processing program: National Institute of Mental Health, https://imagej.nih.gov/ij/download.html.

Reynolds, John M., 2011, Second Edition, An Introduction to Applied and Environmental Geophysics, chapter 7, Electrical Resistivity Methods, ISBN: 978-0-471-48535-3.

Schwarzbach, C., and Spitzer, K., 2005, Two-dimensional inversion of direct current resistivity data using a parallel, multi-objective genetic algorithm: v. 162, p. 685-695, doi:10.1111/j.1365-246X.2005.02702.x.

Toran, L., and Roman, E., 2006, CO 2 outgassing in a combined fracture and conduit karst aquifer near Lititz Spring, Pennsylvania: SPECIAL PAPERS-GEOLOGICAL SOCIETY OF AMERICA, v. 404, p. 275-282, doi:10.1130/2006.2404(23).

Trauth, S.E., Wheeler, B.A., Hiler, W.R., Lawson, R.L., Martin, H.C., and Christian, A.D., 2007, Current Distribution and Relative Abundance of the Crayfish, Mussels, and Aquatic Salamanders of the Spring River, Arkansas: Spring, http://www.wildlifearkansas.com/materials/ProjectReports/T2-1-11 Endemic Crayfish Bouchardina final.pdf.

White, W.B., 1988, Geomorphology and Hydrology of Karst Terrains, p. 220-263.

White, W.B., 2002, Karst hydrology:recent developments and open questions: Engineering Geology, v. 65, p. 85-105, doi:10.1.1.460.1548. 


\section{APPENDICES}

Appendix A. Aerial Imagery Analysis table

\begin{tabular}{|c|c|c|c|c|c|c|}
\hline \multirow[b]{3}{*}{ ID } & Tufa Data Set & \multirow{2}{*}{$\begin{array}{l}\text { Spring River, AR } \\
\text { ation }\end{array}$} & & & & \multirow[b]{3}{*}{ Name (if one } \\
\hline & Location & & & \multicolumn{2}{|c|}{ meters } & \\
\hline & Latitude & Longitude & Estimated Trend & $\begin{array}{l}\text { Estimated } \\
\text { Thickness }\end{array}$ & $\begin{array}{l}\text { Estimated } \\
\text { Length }\end{array}$ & \\
\hline 1 & $36^{\circ} 29^{\prime} 31^{\prime \prime} \mathrm{N}$ & $91^{\circ} 32^{\prime} 11^{\prime \prime} \mathrm{W}$ & 20 & 1.16 & 98.73 & \\
\hline 2 & $36^{\circ} 29^{\prime} 30^{\prime \prime} \mathrm{N}$ & $91^{\circ} 32^{\prime} 10^{\prime \prime} \mathrm{W}$ & 22 & 0.9 & 61.17 & \\
\hline 3 & $36^{\circ} 29^{\prime} 13^{\prime \prime} \mathrm{N}$ & $91^{\circ} 31^{\prime} 51^{\prime \prime} \mathrm{W}$ & 45 & 0.62 & 36.53 & \\
\hline 4 & $36^{\circ} 27^{\prime} 57^{\prime \prime} \mathrm{N}$ & $91^{\circ} 31^{\prime} 49^{\prime \prime} \mathrm{W}$ & 31 & 0.54 & 10.9 & \\
\hline 5 & $36^{\circ} 27^{\prime} 52^{\prime \prime} \mathrm{N}$ & $91^{\circ} 31^{\prime} 41^{\prime \prime} \mathrm{W}$ & 280 & 1.08 & 35.53 & \\
\hline 6 & $36^{\circ} 27^{\prime} 51 " \mathrm{~N}$ & $91^{\circ} 31^{\prime} 40^{\prime \prime} \mathrm{W}$ & 335 & 0.44 & 60.65 & \\
\hline 7 & $36^{\circ} 27^{\prime} 48^{\prime \prime} \mathrm{N}$ & $91^{\circ} 31^{\prime} 36^{\prime \prime} \mathrm{W}$ & 340 & 0.53 & 65.03 & \\
\hline 8 & $36^{\circ} 27^{\prime} 47^{\prime \prime} \mathrm{N}$ & $91^{\circ} 31^{\prime} 36^{\prime \prime} \mathrm{W}$ & 80 & 0.58 & 63.46 & \\
\hline 9 & $36^{\circ} 27^{\prime} 16^{\prime \prime} \mathrm{N}$ & $91^{\circ} 31^{\prime} 42^{\prime \prime} \mathrm{W}$ & 75 & 0.95 & 77.24 & \\
\hline 10 & $36^{\circ} 26^{\prime} 44^{\prime \prime} \mathrm{N}$ & $91^{\circ} 31^{\prime 2} 24^{\prime \prime} \mathrm{W}$ & 278 & 0.41 & 11.66 & \\
\hline 11 & $36^{\circ} 26^{\prime} 17^{\prime \prime} \mathrm{N}$ & $91^{\circ} 31^{\prime} 19^{\prime \prime} \mathrm{W}$ & 300 & 1.24 & 50.08 & \\
\hline 12 & $36^{\circ} 25^{\prime} 48^{\prime \prime} \mathrm{N}$ & $91^{\circ} 31^{\prime} 39^{\prime \prime} \mathrm{W}$ & 275 & 2 & 93.21 & \\
\hline 13 & $36^{\circ} 25^{\prime} 47^{\prime \prime} \mathrm{N}$ & $91^{\circ} 31^{\prime} 33^{\prime \prime} \mathrm{W}$ & 50 & 1.06 & 112.53 & \\
\hline 14 & $36^{\circ} 25^{\prime} 44^{\prime \prime} \mathrm{N}$ & $91^{\circ} 31^{\prime} 01^{\prime \prime} \mathrm{W}$ & 39 & 0.95 & 36.75 & \\
\hline 15 & $36^{\circ} 25^{\prime} 44^{\prime \prime} \mathrm{N}$ & $91^{\circ} 31^{\prime} 01^{\prime \prime} \mathrm{W}$ & 39 & 0.81 & 53.36 & \\
\hline 16 & $36^{\circ} 25^{\prime} 43^{\prime \prime} \mathrm{N}$ & $91^{\circ} 31^{\prime} 01^{\prime \prime} \mathrm{W}$ & 39 & 0.79 & 58.92 & \\
\hline 17 & $36^{\circ} 25^{\prime} 16^{\prime \prime} \mathrm{N}$ & $91^{\circ} 30^{\prime} 56^{\prime \prime} \mathrm{W}$ & 320 & 2.6 & 111.77 & \\
\hline 18 & $36^{\circ} 25^{\prime} 18^{\prime \prime} \mathrm{N}$ & $91^{\circ} 31^{\prime} 16^{\prime \prime} \mathrm{W}$ & 350 & 1.95 & 86.6 & \\
\hline 19 & $36^{\circ} 25^{\prime} 18^{\prime \prime} \mathrm{N}$ & $91^{\circ} 31^{\prime} 16^{\prime \prime} \mathrm{W}$ & 325 & 1.18 & 76.16 & \\
\hline 20 & $36^{\circ} 25^{\prime} 23^{\prime \prime} \mathrm{N}$ & $91^{\circ} 31^{\prime} 30^{\prime \prime} \mathrm{W}$ & 50 & 1.84 & 109.67 & sadlerfall \\
\hline 21 & $36^{\circ} 25^{\prime} 19^{\prime \prime} \mathrm{N}$ & $91^{\circ} 31^{\prime} 42^{\prime \prime} \mathrm{W}$ & 330 & 2.95 & 181.24 & \\
\hline 22 & $36^{\circ} 25^{\prime} 12^{\prime \prime} \mathrm{N}$ & $91^{\circ} 31^{\prime} 52^{\prime \prime} \mathrm{W}$ & 326 & 1.91 & 121.12 & \\
\hline 23 & $36^{\circ} 25^{\prime} 07^{\prime \prime} \mathrm{N}$ & $91^{\circ} 31^{\prime} 51^{\prime \prime} \mathrm{W}$ & 55 & 0.8 & 88.19 & \\
\hline 24 & $36^{\circ} 25^{\prime} 06^{\prime \prime} \mathrm{N}$ & $91^{\circ} 31^{\prime} 51^{\prime \prime} \mathrm{W}$ & 300 & 1.16 & 129.95 & \\
\hline 25 & $36^{\circ} 25^{\prime} 05^{\prime \prime} \mathrm{N}$ & $91^{\circ} 31^{\prime} 49^{\prime \prime} \mathrm{W}$ & 275 & 1.1 & 23.96 & \\
\hline 26 & $36^{\circ} 25^{\prime} 02^{\prime \prime} \mathrm{N}$ & $91^{\circ} 31^{\prime} 48^{\prime \prime} \mathrm{W}$ & 292 & 0.76 & 40.2 & \\
\hline 26 & $36^{\circ} 24^{\prime} 38^{\prime \prime} \mathrm{N}$ & $91^{\circ} 31^{\prime} 44^{\prime \prime} \mathrm{W}$ & 340 & 0.84 & 63.17 & \\
\hline $26 b$ & & & 70 & 1.64 & 83.43 & \\
\hline 27 & $36^{\circ} 24^{\prime} 21^{\prime \prime} \mathrm{N}$ & $91^{\circ} 31^{\prime} 42^{\prime \prime} \mathrm{W}$ & 285 & 2.7 & 75.68 & \\
\hline 28 & $36^{\circ} 23^{\prime} 56^{\prime \prime} \mathrm{N}$ & $91^{\circ} 31^{\prime} 35^{\prime \prime} \mathrm{W}$ & 325 & 0.85 & 156.24 & \\
\hline 29 & $36^{\circ} 23^{\prime} 41^{\prime \prime} \mathrm{N}$ & $91^{\circ} 31^{\prime} 39^{\prime \prime} \mathrm{W}$ & 10 & 5.89 & 114.59 & \\
\hline $29 b$ & & $91^{\circ} 31^{\prime} 39^{\prime \prime} \mathrm{W}$ & 65 & 1.57 & 92.29 & \\
\hline $29 \mathrm{c}$ & & $91^{\circ} 31^{\prime} 41^{\prime \prime} \mathrm{W}$ & 60 & 2.67 & 76.52 & \\
\hline 30 & $36^{\circ} 23^{\prime} 25^{\prime \prime} \mathrm{N}$ & $91^{\circ} 31^{\prime} 53^{\prime \prime} \mathrm{W}$ & 270 & 1.64 & 105.07 & \\
\hline $30 \mathrm{~b}$ & & & 25 & 1.5 & 66.91 & \\
\hline 31 & $36^{\circ} 23^{\prime} 12^{\prime \prime} \mathrm{N}$ & $91^{\circ} 31^{\prime} 49^{\prime \prime} \mathrm{W}$ & 50 & 1.31 & 62.46 & \\
\hline $31 \mathrm{~b}$ & $36^{\circ} 23^{\prime} 11^{\prime \prime} \mathrm{N}$ & $91^{\circ} 31^{\prime} 49^{\prime \prime} \mathrm{W}$ & 325 & 1.43 & 34.58 & \\
\hline $31 \mathrm{c}$ & $36^{\circ} 23^{\prime} 09^{\prime \prime} \mathrm{N}$ & $91^{\circ} 31^{\prime} 50^{\prime \prime} \mathrm{W}$ & 270 & 0.96 & 66.97 & \\
\hline $31 d$ & $36^{\circ} 23^{\prime} 11^{\prime \prime} \mathrm{N}$ & $91^{\circ} 31^{\prime} 52^{\prime \prime} \mathrm{W}$ & 20 & 0.77 & 25.21 & \\
\hline $31 \mathrm{e}$ & $36^{\circ} 23^{\prime} 10^{\prime \prime} \mathrm{N}$ & $91^{\circ} 31^{\prime} 48^{\prime \prime} \mathrm{W}$ & 55 & 0.59 & 66.28 & \\
\hline 32 & $36^{\circ} 23^{\prime} 01^{\prime \prime} \mathrm{N}$ & $91^{\circ} 31^{\prime} 41^{\prime \prime} \mathrm{W}$ & 65 & 1.04 & 88.01 & \\
\hline $32 b$ & $36^{\circ} 23^{\prime} 00^{\prime \prime} \mathrm{N}$ & $91^{\circ} 31^{\prime} 42^{\prime \prime} \mathrm{W}$ & 325 & 0.58 & 50.84 & \\
\hline $32 \mathrm{c}$ & $36^{\circ} 23^{\prime} 00^{\prime \prime} \mathrm{N}$ & $91^{\circ} 31^{\prime} 41^{\prime \prime} \mathrm{W}$ & 25 & 0.33 & 19.26 & \\
\hline $32 d$ & $36^{\circ} 23^{\prime} 00^{\prime \prime} \mathrm{N}$ & $91^{\circ} 31^{\prime} 41^{\prime \prime} \mathrm{W}$ & 305 & 1 & 41.86 & \\
\hline 33 & $36^{\circ} 22^{\prime} 59^{\prime \prime} \mathrm{N}$ & $91^{\circ} 31^{\prime} 40^{\prime \prime} \mathrm{W}$ & 60 & 2.96 & 83.71 & \\
\hline 34 & $36^{\circ} 22^{\prime} 55^{\prime \prime} \mathrm{N}$ & $91^{\circ} 31^{\prime} 55^{\prime \prime} \mathrm{W}$ & 50 & 1.35 & 88.62 & \\
\hline 35 & $36^{\circ} 22^{\prime} 43^{\prime \prime} \mathrm{N}$ & $91^{\circ} 31^{\prime} 34^{\prime \prime} \mathrm{W}$ & 55 & 1.3 & 66.37 & \\
\hline $35 b$ & & & 315 & & & \\
\hline 36 & $36^{\circ} 22^{\prime} 41^{\prime \prime} \mathrm{N}$ & $91^{\circ} 31^{\prime} 34^{\prime \prime} \mathrm{W}$ & 45 & 2.12 & 61.13 & \\
\hline $36 b$ & & & 290 & & & \\
\hline 37 & $36^{\circ} 22^{\prime} 34^{\prime \prime} \mathrm{N}$ & $91^{\circ} 31^{\prime} 30^{\prime \prime} \mathrm{W}$ & 55 & 1.45 & 79.35 & \\
\hline $37 \mathrm{~b}$ & & & 285 & & & \\
\hline
\end{tabular}




\begin{tabular}{|c|c|c|c|c|c|c|}
\hline $37 \mathrm{c}$ & & & 60 & & & \\
\hline 38 & $36^{\circ} 22^{\prime} 32^{\prime \prime N}$ & $91^{\circ} 31^{\prime 2} 27^{\prime \prime} \mathrm{W}$ & 50 & 1.48 & 101.22 & \\
\hline $38 \mathrm{~b}$ & & & 270 & & & \\
\hline 39 & $36^{\circ} 22^{\prime 2} 24^{\prime \prime N}$ & $91^{\circ} 31^{\prime 2} 21^{\prime \prime} \mathrm{W}$ & 40 & 1.03 & 72.65 & \\
\hline 40 & $36^{\circ} 22^{\prime 2} 23^{\prime \prime N}$ & $91^{\circ} 31^{\prime 2} 1^{\prime \prime \mathrm{W}}$ & 60 & 1.16 & 30.94 & \\
\hline 41 & $36^{\circ} 22^{\prime} 15^{\prime \prime} \mathrm{N}$ & $91^{\circ} 31^{\prime 2} 21^{\prime \prime} \mathrm{W}$ & 60 & 0.71 & 53.24 & Myatt Creek \\
\hline 42 & $36^{\circ} 22^{\prime} 12^{\prime \prime} \mathrm{N}$ & 91'31'21"W & 50 & 0.91 & 97.23 & \\
\hline $42 b$ & & & 290 & & & \\
\hline $42 c$ & & & 10 & 0.58 & 18.41 & \\
\hline 43 & $36^{\circ} 21^{\prime} 52^{\prime \prime} \mathrm{N}$ & $91^{\circ} 30^{\prime} 50^{\prime \prime} \mathrm{W}$ & 50 & 0.9 & 76.6 & \\
\hline $43 b$ & & & 5 & & & \\
\hline 44 & $36^{\circ} 21^{\prime} 49^{\prime \prime} \mathrm{N}$ & $91^{\circ} 30^{\prime} 40^{\prime \prime} \mathrm{W}$ & 45 & 0.8 & 62.59 & \\
\hline 45 & $36^{\circ} 21 ' 24 " \mathrm{~N}$ & $91^{\circ} 30^{\prime} 26^{\prime \prime} \mathrm{W}$ & 45 & 1.29 & 112.58 & \\
\hline $45 b$ & & & 330 & & & \\
\hline 46 & $36^{\circ} 20^{\prime} 53^{\prime \prime} \mathrm{N}$ & $91^{\circ} 30^{\prime} 30^{\prime \prime} \mathrm{W}$ & 20 & 1.32 & 50.38 & \\
\hline 47 & $36^{\circ} 20^{\prime} 52^{\prime \prime} \mathrm{N}$ & $91^{\circ} 30^{\prime} 32^{\prime \prime} \mathrm{W}$ & 300 & 0.67 & 95.49 & \\
\hline 48 & $36^{\circ} 20^{\prime} 45^{\prime \prime} \mathrm{N}$ & $91^{\circ} 30^{\prime} 26^{\prime \prime} \mathrm{W}$ & 315 & 2.15 & 147.92 & \\
\hline 49 & $36^{\circ} 20^{\prime} 20^{\prime \prime} \mathrm{N}$ & $91^{\circ} 30^{\prime} 26^{\prime \prime} \mathrm{W}$ & 335 & 1.39 & 63.17 & \\
\hline $49 \mathrm{~b}$ & & & 280 & & & \\
\hline 50 & $36^{\circ} 20^{\prime} 17^{\prime \prime} \mathrm{N}$ & $91^{\circ} 30^{\prime} 31^{\prime \prime} \mathrm{W}$ & 45 & 1.04 & 22.85 & \\
\hline 51 & $36^{\circ} 20^{\prime} 15^{\prime \prime} \mathrm{N}$ & $91^{\circ} 30^{\prime} 31^{\prime \prime} \mathrm{W}$ & 305 & 1.37 & 34.69 & \\
\hline 52 & $36^{\circ} 20^{\prime} 15^{\prime \prime} \mathrm{N}$ & $91^{\circ} 30^{\prime} 31^{\prime \prime} \mathrm{W}$ & 300 & 1.45 & 37.62 & \\
\hline 53 & $36^{\circ} 19^{\prime} 38^{\prime \prime} \mathrm{N}$ & $91^{\circ} 30^{\prime} 32^{\prime \prime} \mathrm{W}$ & 50 & 0.68 & 48.95 & \\
\hline 54 & $36^{\circ} 19^{\prime} 37^{\prime \prime} \mathrm{N}$ & $91^{\circ} 30^{\prime} 31^{\prime \prime} \mathrm{W}$ & 45 & 1.1 & 88.12 & \\
\hline 55 & $36^{\circ} 19^{\prime} 36^{\prime \prime} \mathrm{N}$ & $91^{\circ} 30^{\prime} 29^{\prime \prime} \mathrm{W}$ & 270 & 0.8 & 125.63 & \\
\hline $55 \mathrm{~b}$ & & & 50 & & & \\
\hline $55 \mathrm{c}$ & & & 325 & 1.15 & 18.07 & \\
\hline 56 & $36^{\circ} 19^{\prime} 38^{\prime \prime} \mathrm{N}$ & $91^{\circ} 30^{\prime} 24^{\prime \prime} \mathrm{W}$ & 20 & 0.71 & 22.99 & \\
\hline 57 & $36^{\circ} 19^{\prime} 38^{\prime \prime} \mathrm{N}$ & $91^{\circ} 30^{\prime} 23^{\prime \prime} \mathrm{W}$ & 75 & 0.99 & 46.79 & \\
\hline 58 & $36^{\circ} 19^{\prime} 35^{\prime \prime} \mathrm{N}$ & $91^{\circ} 30^{\prime} 01^{\prime \prime} \mathrm{W}$ & 80 & 0.75 & 68.49 & \\
\hline $58 \mathrm{~b}$ & & & 340 & & & \\
\hline 59 & $36^{\circ} 19^{\prime} 37^{\prime \prime} \mathrm{N}$ & $91^{\circ} 29^{\prime} 59^{\prime \prime} \mathrm{W}$ & 35 & 0.67 & 42.79 & \\
\hline 60 & $36^{\circ} 19^{\prime} 39^{\prime \prime} \mathrm{N}$ & $91^{\circ} 30^{\prime} 01^{\prime \prime} \mathrm{W}$ & 300 & 1.07 & 38.3 & \\
\hline 61 & $36^{\circ} 19^{\prime 2} 27^{\prime \prime} \mathrm{N}$ & $91^{\circ} 29^{\prime} 51^{\prime \prime} \mathrm{W}$ & 325 & 1.5 & 52.62 & \\
\hline 62 & $36^{\circ} 29^{\prime} 28^{\prime \prime} \mathrm{N}$ & $91^{\circ} 29^{\prime} 49^{\prime \prime} \mathrm{W}$ & 350 & 2 & 145.1 & \\
\hline 63 & $36^{\circ} 19^{\prime} 15^{\prime \prime} \mathrm{N}$ & $91^{\circ} 29^{\prime} 41^{\prime \prime} \mathrm{W}$ & 30 & 1.04 & 19.6 & \\
\hline 64 & $36^{\circ} 19^{\prime} 12^{\prime \prime} \mathrm{N}$ & $91^{\circ} 29^{\prime} 50^{\prime \prime} \mathrm{W}$ & 305 & 3.47 & 75.44 & S Fork \\
\hline 65 & $36^{\circ} 19^{\prime} 05^{\prime \prime} \mathrm{N}$ & $91^{\circ} 29^{\prime} 40^{\prime \prime} \mathrm{W}$ & 340 & 3.62 & 217.31 & \\
\hline $65 \mathrm{~b}$ & & & 290 & & & \\
\hline $65 \mathrm{c}$ & & & 50 & & & \\
\hline $65 \mathrm{~d}$ & & & 5 & 2.5 & 57.05 & \\
\hline 66 & $36^{\circ} 18^{\prime} 48^{\prime \prime} \mathrm{N}$ & $91^{\circ} 28^{\prime} 40^{\prime \prime} \mathrm{W}$ & 350 & 0.5 & 50.98 & Fordy island creek \\
\hline 67 & $36^{\circ} 18^{\prime} 45^{\prime \prime} \mathrm{N}$ & $91^{\circ} 28^{\prime} 16^{\prime \prime} \mathrm{W}$ & 45 & 1.23 & 75.68 & \\
\hline $67 \mathrm{~b}$ & & & 305 & & & \\
\hline 68 & $36^{\circ} 18^{\prime} 43^{\prime \prime} \mathrm{N}$ & $91^{\circ} 21^{\prime} 16^{\prime \prime} \mathrm{W}$ & 5 & 0.89 & 60.75 & \\
\hline $68 \mathrm{~b}$ & & & 50 & & & \\
\hline 69 & $36^{\circ} 18^{\prime} 42^{\prime \prime} \mathrm{N}$ & $91^{\circ} 28^{\prime} 18^{\prime \prime} \mathrm{W}$ & 296 & 1.37 & 63.44 & \\
\hline 70 & $36^{\circ} 18^{\prime} 40^{\prime \prime} \mathrm{N}$ & $91^{\circ} 28^{\prime} 18^{\prime \prime} \mathrm{W}$ & 50 & 1.41 & 75.09 & \\
\hline $70 \mathrm{~b}$ & & & 350 & & & \\
\hline 71 & $36^{\circ} 18^{\prime} 41^{\prime \prime} \mathrm{N}$ & $91^{\circ} 28^{\prime} 15^{\prime \prime} \mathrm{W}$ & 300 & 0.84 & 20.67 & \\
\hline 72 & $36^{\circ} 18^{\prime} 40^{\prime \prime} \mathrm{N}$ & $91^{\circ} 28^{\prime} 13^{\prime \prime} \mathrm{W}$ & 275 & 0.46 & 11.44 & \\
\hline 73 & $36^{\circ} 18^{\prime} 46^{\prime \prime} \mathrm{N}$ & $91^{\circ} 28^{\prime} 07^{\prime \prime} \mathrm{W}$ & 280 & 0.9 & 41.04 & \\
\hline $73 b$ & & & 340 & & & \\
\hline $73 c$ & & & 20 & & & \\
\hline $73 d$ & & & 280 & & & \\
\hline $73 e$ & & & 30 & & & \\
\hline 74 & $36^{\circ} 18^{\prime} 34^{\prime \prime} \mathrm{N}$ & $91^{\circ} 27^{\prime} 44^{\prime \prime} \mathrm{W}$ & 310 & 1.54 & 119.85 & Flat creek \\
\hline 75 & $36^{\circ} 18^{\prime} 31^{\prime \prime} \mathrm{N}$ & $91^{\circ} 27^{\prime} 43^{\prime \prime} \mathrm{W}$ & 15 & 0.66 & 59.13 & Flat creek \\
\hline 76 & $36^{\circ} 18^{\prime} 07^{\prime \prime} \mathrm{N}$ & $91^{\circ} 27^{\prime} 05^{\prime \prime} \mathrm{W}$ & 340 & 0.47 & 206.72 & Cabin Creek \\
\hline $76 b$ & & & 20 & & & \\
\hline $76 \mathrm{c}$ & & & 275 & & & \\
\hline 77 & $36^{\circ} 18^{\prime} 08^{\prime \prime} \mathrm{N}$ & $91^{\circ} 27^{\prime} 03^{\prime \prime} \mathrm{W}$ & 355 & 1.25 & 67.11 & Cabin Creek \\
\hline $77 b$ & & & 77 & & & \\
\hline 78 & $36^{\circ} 18^{\prime} 05^{\prime \prime} \mathrm{N}$ & $91^{\circ} 27^{\prime} 04^{\prime \prime} \mathrm{W}$ & 35 & 0.88 & 97.71 & Cabin Creek \\
\hline 79 & $36^{\circ} 18^{\prime} 08^{\prime \prime} \mathrm{N}$ & $91^{\circ} 27^{\prime} 01^{\prime \prime} \mathrm{W}$ & 65 & 0.96 & 21.39 & Cabin Creek \\
\hline 80 & $36^{\circ} 18^{\prime} 07^{\prime \prime} \mathrm{N}$ & $91^{\circ} 27^{\prime} 01^{\prime \prime} \mathrm{W}$ & 40 & 0.5 & 20.85 & Cabin Creek \\
\hline
\end{tabular}




\begin{tabular}{|c|c|c|c|c|c|c|}
\hline 81 & $36^{\circ} 18^{\prime} 06^{\prime \prime} \mathrm{N}$ & $91^{\circ} 27^{\prime} 02^{\prime \prime} \mathrm{W}$ & 330 & 0.85 & 37 & Cabin Creek \\
\hline 82 & $36^{\circ} 18^{\prime} 04^{\prime \prime} \mathrm{N}$ & $91^{\circ} 27^{\prime} 03^{\prime \prime} \mathrm{W}$ & 70 & 0.76 & 33.39 & Cabin Creek \\
\hline 83 & $36^{\circ} 18^{\prime} 04^{\prime \prime} \mathrm{N}$ & $91^{\circ} 27^{\prime} 02^{\prime \prime} \mathrm{W}$ & 40 & 1.03 & 69.64 & Cabin Creek \\
\hline 84 & $36^{\circ} 18^{\prime} 04^{\prime \prime} \mathrm{N}$ & $91^{\circ} 27^{\prime} 05^{\prime \prime} \mathrm{W}$ & 300 & 1.24 & 47.37 & Cabin Creek \\
\hline $84 b$ & & & 358 & & & \\
\hline 85 & $36^{\circ} 18^{\prime} 02^{\prime \prime} \mathrm{N}$ & $91^{\circ} 27^{\prime} 02^{\prime \prime} \mathrm{W}$ & 10 & 1.53 & 72.37 & Cabin Creek \\
\hline 86 & $36^{\circ} 17^{\prime} 28^{\prime \prime} \mathrm{N}$ & $91^{\circ} 26^{\prime} 12^{\prime \prime} \mathrm{W}$ & 320 & 0.43 & 153.33 & Sugar Creek \\
\hline $86 b$ & & & 350 & & & \\
\hline $86 \mathrm{c}$ & & & 55 & & & \\
\hline 87 & $36^{\circ} 17^{\prime} 30^{\prime \prime} \mathrm{N}$ & $91^{\circ} 26^{\prime} 07^{\prime \prime} \mathrm{W}$ & 0 & 1.1 & 25.68 & Sugar Creek \\
\hline 88 & $36^{\circ} 17^{\prime} 27^{\prime \prime} \mathrm{N}$ & $91^{\circ} 26^{\prime} 07^{\prime \prime} \mathrm{W}$ & 30 & 2.02 & 119.81 & Sugar Creek \\
\hline $88 \mathrm{~b}$ & & & 280 & & & \\
\hline $88 \mathrm{c}$ & & & 340 & & & \\
\hline $88 \mathrm{~d}$ & & & 10 & & & \\
\hline 89 & $36^{\circ} 17^{\prime} 26^{\prime \prime} \mathrm{N}$ & $91^{\circ} 26^{\prime} 07^{\prime \prime} \mathrm{W}$ & 60 & 1.31 & 9.23 & Sugar Creek \\
\hline 90 & $36^{\circ} 17^{\prime} 29^{\prime \prime} \mathrm{N}$ & $91^{\circ} 26^{\prime} 04^{\prime \prime} \mathrm{W}$ & 350 & 0.75 & 22.99 & Sugar Creek \\
\hline 91 & $36^{\circ} 17^{\prime} 17^{\prime \prime} \mathrm{N}$ & $91^{\circ} 25^{\prime} 32^{\prime \prime} \mathrm{W}$ & 50 & 0.92 & 76.82 & Pierce Creek \\
\hline $91 b$ & & & 350 & & & \\
\hline 92 & $36^{\circ} 17^{\prime} 07^{\prime \prime} \mathrm{N}$ & $91^{\circ} 25^{\prime} 19^{\prime \prime} \mathrm{W}$ & 275 & 1.25 & 120.32 & \\
\hline $92 b$ & & & 35 & & & \\
\hline 93 & $36^{\circ} 16^{\prime} 52^{\prime \prime} \mathrm{N}$ & $91^{\circ} 25^{\prime} 10^{\prime \prime} \mathrm{W}$ & 320 & 1.06 & 119.72 & \\
\hline $93 b$ & & & 70 & & & \\
\hline 94 & $36^{\circ} 16^{\prime} 36^{\prime \prime} \mathrm{N}$ & $91^{\circ} 24^{\prime} 49^{\prime \prime} \mathrm{W}$ & 350 & 0.61 & 95.36 & Sawmill Hollow \\
\hline 95 & $36^{\circ} 16^{\prime} 32^{\prime \prime} \mathrm{N}$ & $91^{\circ} 24^{\prime} 49^{\prime \prime} \mathrm{W}$ & 30 & 0.5 & 20.41 & Sawmill Hollow \\
\hline 96 & $36^{\circ} 16^{\prime} 32^{\prime \prime} \mathrm{N}$ & $91^{\circ} 24^{\prime} 46^{\prime \prime} \mathrm{W}$ & 60 & 0.4 & 20.27 & Sawmill Hollow \\
\hline 97 & $36^{\circ} 16^{\prime} 31^{\prime \prime} \mathrm{N}$ & $91^{\circ} 24^{\prime} 45^{\prime \prime} \mathrm{W}$ & 30 & 0.43 & 21.45 & Sawmill Hollow \\
\hline 98 & $36^{\circ} 16^{\prime} 31^{\prime \prime} \mathrm{N}$ & $91^{\circ} 24^{\prime} 44^{\prime \prime} \mathrm{W}$ & 40 & 0.41 & 19.22 & Sawmill Hollow \\
\hline 99 & $36^{\circ} 16^{\prime} 37^{\prime \prime} \mathrm{N}$ & $91^{\circ} 24^{\prime} 41^{\prime \prime} \mathrm{W}$ & 340 & 1.43 & 98.13 & Sawmill Hollow \\
\hline $99 b$ & & & 70 & & & \\
\hline $99 \mathrm{c}$ & & & 10 & & & \\
\hline 100 & $36^{\circ} 16^{\prime} 06^{\prime \prime} \mathrm{N}$ & $91^{\circ} 24^{\prime} 16^{\prime \prime} \mathrm{W}$ & 350 & 0.9 & 47.59 & \\
\hline 101 & $36^{\circ} 15^{\prime} 35^{\prime \prime} \mathrm{N}$ & $91^{\circ} 24^{\prime} 27^{\prime \prime} \mathrm{W}$ & 10 & 1.05 & 16.65 & \\
\hline $101 \mathrm{~b}$ & & & 90 & & & \\
\hline 102 & $36^{\circ} 15^{\prime} 32^{\prime \prime} \mathrm{N}$ & $91^{\circ} 24^{\prime} 29^{\prime \prime} \mathrm{W}$ & 330 & 0.3 & 24.97 & \\
\hline 103 & $36^{\circ} 15^{\prime} 21^{\prime \prime} \mathrm{N}$ & $91^{\circ} 24^{\prime} 29^{\prime \prime} \mathrm{W}$ & 285 & 1.53 & 43.12 & \\
\hline 104 & $36^{\circ} 14^{\prime} 29^{\prime \prime} \mathrm{N}$ & $91^{\circ} 23^{\prime} 31^{\prime \prime} \mathrm{W}$ & 52 & 1.76 & 77.95 & Rock Creek \\
\hline $104 \mathrm{~b}$ & & & 340 & & & \\
\hline 105 & $36^{\circ} 14^{\prime} 28^{\prime \prime} \mathrm{N}$ & $91^{\circ} 23 ' 29^{\prime \prime} \mathrm{W}$ & 357 & 1.31 & 82.3 & Rock Creek \\
\hline $105 \mathrm{~b}$ & & & 70 & & & \\
\hline 106 & $36^{\circ} 14^{\prime} 38^{\prime \prime} \mathrm{N}$ & $91^{\circ} 22^{\prime} 25^{\prime \prime} \mathrm{W}$ & 272 & 1.54 & 87.87 & Ball Hollow \\
\hline $106 \mathrm{~b}$ & & & 40 & & & \\
\hline $106 \mathrm{c}$ & & & 345 & & & \\
\hline 107 & $36^{\circ} 15^{\prime} 05^{\prime \prime} \mathrm{N}$ & $91^{\circ} 20^{\prime} 55^{\prime \prime} \mathrm{W}$ & 282 & 0.32 & 14.53 & \\
\hline 108 & $36^{\circ} 14^{\prime} 24^{\prime \prime} \mathrm{N}$ & $91^{\circ} 18^{\prime} 16^{\prime \prime} \mathrm{W}$ & 295 & 1.63 & 45.49 & Jeff Creek \\
\hline 109 & $36^{\circ} 14^{\prime} 51^{\prime \prime} \mathrm{N}$ & $91^{\circ} 17^{\prime} 41^{\prime \prime} \mathrm{W}$ & 340 & 0.54 & 30.73 & \\
\hline 110 & $36^{\circ} 14^{\prime} 52^{\prime \prime} \mathrm{N}$ & $91^{\circ} 17^{\prime} 33^{\prime \prime} \mathrm{W}$ & 20 & 0.48 & 29.77 & \\
\hline 111 & $36^{\circ} 13^{\prime} 30^{\prime \prime} \mathrm{N}$ & $91^{\circ} 14^{\prime} 32^{\prime \prime} \mathrm{W}$ & 80 & 1.15 & 31.35 & \\
\hline 112 & $36^{\circ} 14^{\prime} 28^{\prime \prime} \mathrm{N}$ & $91^{\circ} 13^{\prime} 58^{\prime \prime} \mathrm{W}$ & 50 & 0.52 & 26.66 & \\
\hline 113 & $36^{\circ} 09^{\prime} 46^{\prime \prime} \mathrm{N}$ & $91^{\circ} 07^{\prime} 57^{\prime \prime} \mathrm{W}$ & 358 & 0.61 & 25.67 & \\
\hline
\end{tabular}


Appendix B. Flyer that was handed out to landowners.

\section{Student·Project--Missouri-State-University}

$\rightarrow$ Hello!·I·am·a·geology·student·at·Missouri-State-University·and·I·would·like-to·

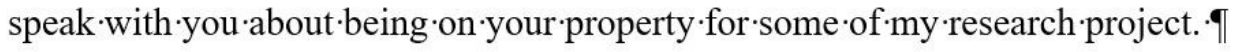

-The·Project:-

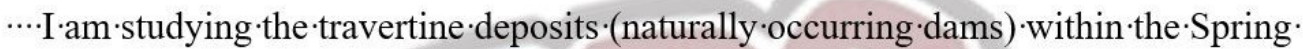
River. 'A large number of these have formed on the river from Mammoth Spring to

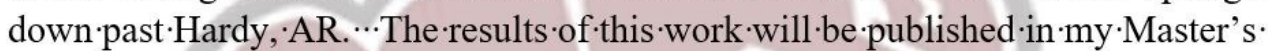
Thesis 'which will be publicly available through $\cdot$ Missouri-State-University's 'Library ·

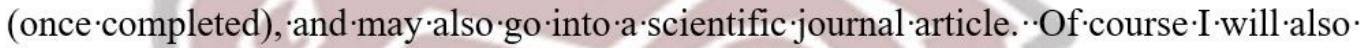

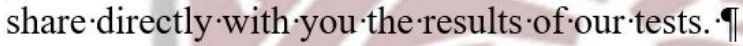

-Planned·Tasks

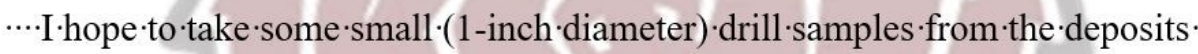

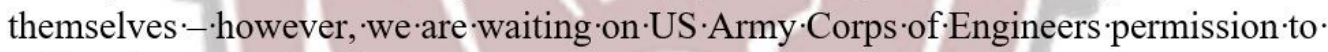
collect these-samples. 1

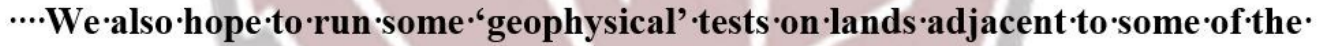

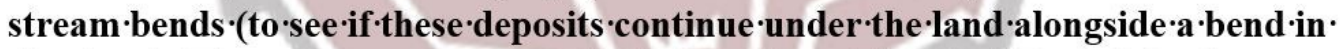

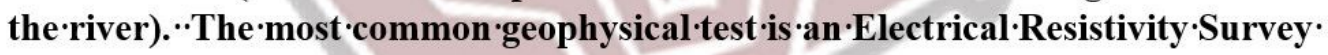

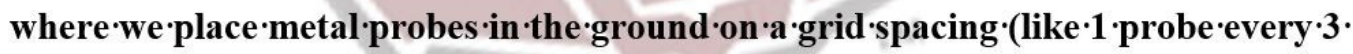

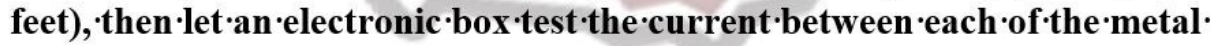
electrodes 'for'about 2 ' hours 'per'grid. $\cdots$ This ' is the test 'we'would 'most like'your'

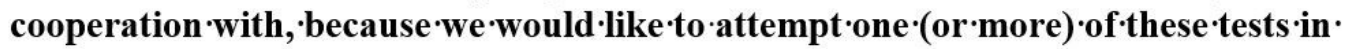

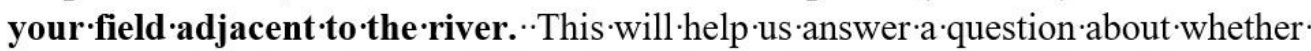

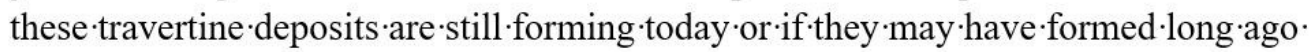

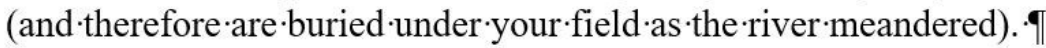

-Contacting·Us: $\oplus$

.Please·contact·me·by·email:·Engelbart18@live.missouristate.edu·or·phone:(xxx)·xxx$\operatorname{xxxx} \cdot \cdot \cdot$

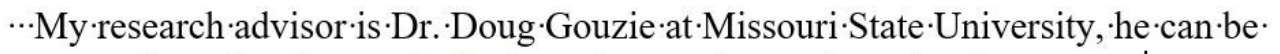

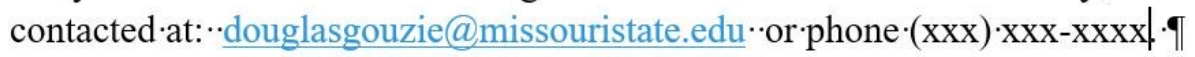

\section{ब}

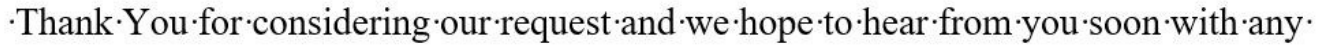

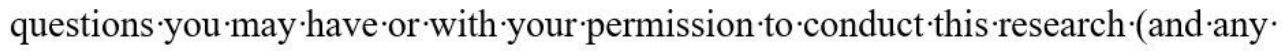

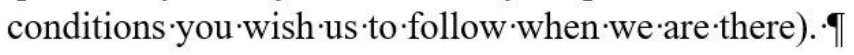




\section{Appendix C. Core Log}

\begin{tabular}{|c|c|c|c|c|c|c|}
\hline Core Box: & $1-\mathrm{a}$ & & & & $\begin{array}{l}\text { Number of } \\
\text { Cores: }\end{array}$ & \multirow{2}{*}{$\begin{array}{r}1 \text { of } 4 \\
9 / 12 / \\
2019 \\
\end{array}$} \\
\hline \multirow[t]{2}{*}{ Location: } & \multirow{2}{*}{\multicolumn{2}{|c|}{$\begin{array}{c}\text { Riverside Resort Camp and } \\
\text { Canoe, AR } \\
\end{array}$}} & Lat: & $36^{\circ} 25^{\prime} 47.5^{\prime \prime} \mathrm{N}$ & \multirow[t]{2}{*}{ Date Cored: } & \\
\hline & & & Long: & $91^{\circ} 31^{\prime} 33.8^{\prime \prime} \mathrm{W}$ & & \\
\hline Core Number: & \multicolumn{2}{|c|}{ RR 1} & & Total Length: & \multicolumn{2}{|l|}{$36.0^{\prime \prime}$} \\
\hline $\begin{array}{l}\text { Depth Interval: } \\
\text { (in) }\end{array}$ & & Porosity: $\quad(\%)$ & \multicolumn{4}{|c|}{ Description: } \\
\hline $0-3.0$ & & 31.5 & \multicolumn{4}{|c|}{$\begin{array}{l}\text { All tufa, mostly smaller voids on the surface, brown to tan to } \\
\text { cream in color, some dark brown, does line up with the next } \\
\text { piece, better cemented }\end{array}$} \\
\hline $3.0-6.75$ & $\begin{array}{l}\text { Thin } \\
\text { sectioned } \\
\text { (2) }\end{array}$ & 28.7 & \multicolumn{4}{|c|}{$\begin{array}{c}\text { All tufa, lower portion of core has very few voids, has several } \\
\text { big pores but generally smaller pores, brown to tan to cream in } \\
\text { color, some dark brown, lines up with next piece, better } \\
\text { cemented }\end{array}$} \\
\hline $6.75-10.6$ & & 27.5 & \multicolumn{4}{|c|}{$\begin{array}{c}\text { All tufa, some spots on the core have very small voids, no large } \\
\text { pores, half of core is missing due to a really large void, a lot of } \\
\text { dark brown, brown to tan to cream in color, lines up with next } \\
\text { piece, better cemented }\end{array}$} \\
\hline $10.6-14.1$ & & 32 & \multicolumn{4}{|c|}{$\begin{array}{l}\text { All tufa, some small voids, mostly larger voids, top of core lines } \\
\text { up with missing portion of previous core due to large void } \\
\text { space, brown to tan to cream, some dark brown, better cemented }\end{array}$} \\
\hline $14.1-19.1$ & & not measurable & \multicolumn{4}{|c|}{$\begin{array}{c}\text { Mostly gravel (chert), some sand, a few pieces of shells, a small } \\
\text { piece of tufa, not many voids, brown to tan in color, poorly } \\
\text { cemented. }\end{array}$} \\
\hline $19.1-36.0$ & & & & & & \\
\hline
\end{tabular}




\begin{tabular}{|c|c|c|c|c|c|c|}
\hline Core Box: & $1-\mathrm{a}$ & & & & $\begin{array}{l}\text { Number of } \\
\text { Cores: }\end{array}$ & 2 of 4 \\
\hline \multirow[t]{2}{*}{ Location: } & \multirow{2}{*}{\multicolumn{2}{|c|}{$\begin{array}{c}\text { Riverside Resort Camp and } \\
\text { Canoe, AR } \\
\end{array}$}} & Lat: & $36^{\circ} 25^{\prime} 47.5^{\prime \prime} \mathrm{N}$ & $\begin{array}{l}\text { Date } \\
\text { Cored: }\end{array}$ & $9 / 12 / 2019$ \\
\hline & & & Long: & $91^{\circ} 31^{\prime} 34.2^{\prime \prime} \mathrm{W}$ & & \\
\hline Core Number: & \multicolumn{2}{|l|}{ RR 2} & & Total Length: & \multicolumn{2}{|l|}{$40.0^{\prime \prime}$} \\
\hline $\begin{array}{l}\text { Depth Interval: } \\
\text { (in) }\end{array}$ & & Porosity: $\quad(\%)$ & \multicolumn{4}{|c|}{ Description: } \\
\hline $0-3.5$ & & 31.2 & \multicolumn{4}{|c|}{$\begin{array}{l}\text { All tufa, mostly smaller voids on the surface, one really large } \\
\text { void in lower section, brown to tan to cream in color, some dark } \\
\text { brown, does line up with the next piece, better cemented }\end{array}$} \\
\hline $3.5-11.2$ & & 38.1 & \multirow{2}{*}{\multicolumn{4}{|c|}{$\begin{array}{l}\text { All tufa, has very few voids in spots, has two large pores, } \\
\text { several big pores and smaller pores, brown to tan to cream in } \\
\text { color, some dark brown, some green, has shells at bottom, lines } \\
\text { up with next piece, well cemented } \\
\text { Tufa and small amounts of chert, one large void, generally small } \\
\text { voids, brown to tan to cream in color, some green in large void, } \\
\text { has shells in the top portion, lines up with next piece, poorly } \\
\text { cemented }\end{array}$}} \\
\hline $11.2-12.9$ & & 30.8 & & & & \\
\hline $12.9-16.0$ & & 36.6 & \multicolumn{4}{|c|}{$\begin{array}{l}\text { All tufa, some small voids, mostly larger voids, one large void } \\
\text { at bottom that continues on to next piece, brown to tan to cream, } \\
\text { some dark brown, some shells mid to top of sample, better } \\
\text { cemented }\end{array}$} \\
\hline $16.0-20.1$ & $\begin{array}{l}\text { Thin } \\
\text { sectioned } \\
\text { (2) }\end{array}$ & 42.8 & \multicolumn{4}{|c|}{$\begin{array}{l}\text { All tufa, one side has larger voids, one side has small voids to } \\
\text { none, one large pore down the middle that lines up with } \\
\text { previous piece, brown to tan to cream, dark brown in large void, } \\
\text { a grey color ring around weaker cemented portion, some shells, } \\
\text { well cemented to better cemented }\end{array}$} \\
\hline $20.1-40.0$ & & & & & & \\
\hline
\end{tabular}




\begin{tabular}{|c|c|c|c|c|c|c|}
\hline Core Box: & \multicolumn{4}{|l|}{$1-\mathrm{a}$} & $\begin{array}{l}\text { Number } \\
\text { of Cores: }\end{array}$ & 3 of 4 \\
\hline \multirow[t]{2}{*}{ Location: } & \multirow{2}{*}{\multicolumn{2}{|c|}{$\begin{array}{l}\text { Riverside Resort Camp and } \\
\text { Canoe, AR }\end{array}$}} & Lat: & $36^{\circ} 25^{\prime} 47.2^{\prime \prime} \mathrm{N}$ & $\begin{array}{l}\text { Date } \\
\text { Cored: }\end{array}$ & $9 / 12 / 2019$ \\
\hline & & & Long: & $91^{\circ} 31^{\prime} 34.2^{\prime \prime} \mathrm{W}$ & & \\
\hline Core Number: & \multicolumn{2}{|c|}{ RR 3} & & Total Length: & \multicolumn{2}{|l|}{$30.0^{\prime \prime}$} \\
\hline $\begin{array}{l}\text { Depth Interval: } \\
\text { (in) }\end{array}$ & & Porosity: $\quad(\%)$ & \multicolumn{4}{|c|}{ Description: } \\
\hline $0-0.75$ & & not measurable & \multicolumn{4}{|c|}{$\begin{array}{l}\text { All tufa, mostly small voids on the surface, brown to tan in } \\
\text { color, lines up with next piece, poorly cemented. }\end{array}$} \\
\hline $0.75-4.75$ & $\begin{array}{l}\text { Thin } \\
\text { sectioned } \\
\quad(2)\end{array}$ & 32.2 & \multicolumn{4}{|c|}{$\begin{array}{l}\text { All tufa, several bigger voids and smaller voids, brown to tan to } \\
\text { cream in color, some dark brown, has shells at bottom, lines up } \\
\text { with next piece, better cemented. }\end{array}$} \\
\hline $4.75-7.1$ & & 26.4 & \multicolumn{4}{|c|}{$\begin{array}{l}\text { All tufa, one large void at the bottom, generally small voids and } \\
\text { some larger voids, color is dark brown to brown to tan and has } \\
\text { some red, lines up with next piece, better cemented. }\end{array}$} \\
\hline $7.1-9.1$ & & 27.1 & \multicolumn{4}{|c|}{$\begin{array}{l}\text { All tufa, some small voids, mostly larger voids and has a large } \\
\text { void at top and one at bottom, brown to tan to cream, some dark } \\
\text { brown, lines up with next piece, better to poorly cemented at } \\
\text { bottom. }\end{array}$} \\
\hline $9.1-15.7$ & & 38.5 & \multicolumn{4}{|c|}{$\begin{array}{l}\text { All tufa, generally smaller voids on the surface with larger } \\
\text { voids and on lager one at the bottom, brown to tan to cream in } \\
\text { color, dark brown in larger voids, well cemented. }\end{array}$} \\
\hline $15.7-19.7$ & & not measurable & \multicolumn{4}{|c|}{$\begin{array}{l}\text { Tufa with some chert, it is broken up into pieces, the bigger } \\
\text { pieces have smaller voids, brown to tan to cream in color, some } \\
\text { dark brown, has shells in some pieces, and poorly to really poor } \\
\text { cemented. }\end{array}$} \\
\hline $19.7-30.0$ & & & & & & \\
\hline
\end{tabular}




\begin{tabular}{|c|c|c|c|c|c|c|}
\hline Core Box: & $1-\mathrm{a} \& 1-\mathrm{b}$ & & & & Number of Cores: & 4 of 4 \\
\hline \multirow[t]{2}{*}{ Location: } & \multirow{2}{*}{\multicolumn{2}{|c|}{$\begin{array}{l}\text { Riverside Resort Camp and } \\
\text { Canoe, AR } \\
\end{array}$}} & Lat: & $\begin{array}{l}36^{\circ} 25^{\prime} 47.4^{\prime \prime} \\
\mathrm{N}\end{array}$ & \multirow[t]{2}{*}{ Date Cored: } & \multirow[t]{2}{*}{$9 / 12 / 2019$} \\
\hline & & & Long: & $\begin{array}{l}91^{\circ} 31^{\prime} 34.8^{\prime \prime} \\
\mathrm{W}\end{array}$ & & \\
\hline Core Number: & \multicolumn{2}{|l|}{ RR 4} & & Total Length: & \multicolumn{2}{|l|}{$36.0^{\prime \prime}$} \\
\hline Depth Interval: (in) & & Porosity: $\quad(\%)$ & \multicolumn{4}{|c|}{ Decription: } \\
\hline $0-2.3$ & & 29.7 & \multicolumn{4}{|c|}{$\begin{array}{l}\text { All tufa, mostly smaller voids on the surface, has really small } \\
\text { voids at the bottom, brown to tan to cream in color, some dark } \\
\text { brown, poorly cemented till bottom portion. }\end{array}$} \\
\hline $2.3-3.0$ & & not measurable & \multicolumn{4}{|c|}{$\begin{array}{l}\text { All tufa, smaller voids, has a large void at bottom that lines up } \\
\text { wit hnext piece, brown to tan to cream in color, lines up with next } \\
\text { piece, better to poorly cemented at bottom. }\end{array}$} \\
\hline $3.0-4.5$ & & 33.0 & \multicolumn{4}{|c|}{$\begin{array}{l}\text { All tufa, mostly small voids, some larger voids, has a large void } \\
\text { at top that lines up with previous piece and a large void in the } \\
\text { middle, brown to tan to cream, poorly cemented. }\end{array}$} \\
\hline $4.5-6.5$ & & 37.3 & \multicolumn{4}{|c|}{$\begin{array}{l}\text { All tufa, some larger voids towards top and small voids at } \\
\text { bottom, one large void at the bottom, brown to tan to cream in } \\
\text { color, some dark brown, poorly to better cemented at bottom. }\end{array}$} \\
\hline $6.5-10.3$ & & not measurable & \multicolumn{4}{|c|}{$\begin{array}{l}\text { All tufa, all small voids, brown to tan in color, and a grey color } \\
\text { seperation, poorly to better cemented. }\end{array}$} \\
\hline $10.3-11.3$ & & not measurable & \multicolumn{4}{|c|}{$\begin{array}{l}\text { All tufa, smaller to very smal voids, brown to tan to cream in } \\
\text { color, better to poorly cemented at bottom. }\end{array}$} \\
\hline $11.3-12.5$ & & not measurable & \multicolumn{4}{|c|}{$\begin{array}{c}\text { All tufa, smaller to some larger voids, brown to tan in color, } \\
\text { poorly cemented }\end{array}$} \\
\hline $12.5-15.5$ & & 26.8 & \multicolumn{4}{|c|}{$\begin{array}{l}\text { All tufa, large to small voids, brown to tan to cream in color, } \\
\text { some dark brown spots, poorly cemented but better cemented in a } \\
\text { few spots. }\end{array}$} \\
\hline $15.5-17.2$ & $\begin{array}{l}\text { Thin } \\
\text { sectioned } \\
\text { (1) }\end{array}$ & 31.1 & \multicolumn{4}{|c|}{$\begin{array}{l}\text { All tufa, has a void between this piece and the previous piece, } \\
\text { small to larger voids, brown to tqn in color, top of sample is dark } \\
\text { brown, better to poorly cemented at bottom. }\end{array}$} \\
\hline $17.2-18.8$ & & not measurable & \multicolumn{4}{|c|}{$\begin{array}{l}\text { All tufa, has generally smaller voids, brown to tan in color, had a } \\
\text { dark bron tint, poorly cemented. }\end{array}$} \\
\hline $18.8-20.4$ & & not measurable & \multicolumn{4}{|c|}{$\begin{array}{c}\text { All tufa, half of it is a void space and the other hald has smaller } \\
\text { voids, brown to tan on side with smaller voids, side that is a void } \\
\text { is dark brown, poorly cemented and well cemented on side with } \\
\text { large void. }\end{array}$} \\
\hline $20.4-21.4$ & & not measurable & \multicolumn{4}{|c|}{$\begin{array}{c}\text { Chert noudles and shells cemented into the tufa with no real } \\
\text { voids, better cemented. }\end{array}$} \\
\hline
\end{tabular}




\begin{tabular}{|c|c|c|c|}
\hline $21.4-22.4$ & not measurable & $\begin{array}{c}\text { Chert noudles and shells cemented into the tufa with no real } \\
\text { voids, the bottom is the top of a large void space, better } \\
\text { cemented. }\end{array}$ \\
\hline $22.4-27.9$ & not measurable & $\begin{array}{c}\text { Little recovery, it is all sand, has chect noudles, broken pices of } \\
\text { tufa, and shells in sample. }\end{array}$ \\
\hline $27.9-36.0$ & & \\
\hline
\end{tabular}




\begin{tabular}{|c|c|c|c|c|c|c|}
\hline Core Box: & 2 & & & & $\begin{array}{l}\text { Number } \\
\text { of Cores: }\end{array}$ & 1 of 1 \\
\hline \multirow[t]{2}{*}{ Location: } & \multirow{2}{*}{\multicolumn{2}{|c|}{ Saddler Falls, AR }} & Lat: & $36^{\circ} 25^{\prime} 6.3^{\prime \prime} \mathrm{N}$ & $\begin{array}{l}\text { Date } \\
\text { Cored: }\end{array}$ & $10 / 10 / 2019$ \\
\hline & & & Long: & $91^{\circ} 31^{\prime} 51.4^{\prime \prime} \mathrm{W}$ & & \\
\hline Core Number: & \multicolumn{2}{|l|}{ SS 1} & & Total Length: & \multicolumn{2}{|l|}{$45.5^{\prime \prime}$} \\
\hline $\begin{array}{l}\text { Depth Interval: } \\
\text { (in) }\end{array}$ & & Porosity: $\quad(\%)$ & \multicolumn{4}{|c|}{ Description: } \\
\hline $0-4.25$ & & 44.5 & \multicolumn{4}{|c|}{$\begin{array}{l}\text { All tufa, generally smaller and larger pores, one large pore at the } \\
\text { bottom that lines up with the next piece, dark brow to brown to } \\
\text { tan in color, better to well cemented. }\end{array}$} \\
\hline $4.25-5.25$ & & not measurable & \multicolumn{4}{|c|}{$\begin{array}{l}\text { All tufa, with small voids and a large void at the top that lines up } \\
\text { with previous piece, dark brown at top and brown to tan in color, } \\
\text { sample lines up with next piece, better cemented. }\end{array}$} \\
\hline $5.25-12.8$ & & 34.2 & \multicolumn{4}{|c|}{$\begin{array}{l}\text { Tufa with some chert, small to larger voids, has three large voids } \\
\text { one toward the top in the middle and toward the bottom, brown } \\
\text { to tan, dark brown in one of the large voids, has shells through } \\
\text { sample, line up with next piece, better to well cemented and } \\
\text { poorly cemented at bottom. }\end{array}$} \\
\hline $12.8-16.3$ & & 28.0 & \multicolumn{4}{|c|}{$\begin{array}{l}\text { Tufa with some chert, smaller to larger voids, two large voids } \\
\text { one at top and other at bottom, brown to tan in color, large void } \\
\text { at bottom is dark brown, has shells in through sample, poorly to } \\
\text { better cemented. }\end{array}$} \\
\hline $16.3-18.0$ & & not measurable & \multicolumn{4}{|c|}{$\begin{array}{c}\text { Broken up pieces of tufa, has some chert noodles and shells in } \\
\text { them. }\end{array}$} \\
\hline $18.0-21.0$ & $\begin{array}{l}\text { bottom } \\
\text { of run } 1\end{array}$ & & & & & \\
\hline $21.0-37.0$ & $\begin{array}{l}\text { bottom } \\
\text { of run } 2\end{array}$ & not measurable & \multicolumn{4}{|c|}{$\begin{array}{l}\text { Several broken up pieces of tufa, it has shells and chert in some } \\
\text { of the pieces, some samples are just cored chert. }\end{array}$} \\
\hline $37.0-37.5$ & $\begin{array}{l}\text { bottom } \\
\text { of run } 3\end{array}$ & not measurable & \multicolumn{4}{|c|}{$\begin{array}{l}\text { A few pieces of tufa and a few chert nodules with tufa on them, } \\
\text { recovered more sample then what was cored in the field and } \\
\text { measured. }\end{array}$} \\
\hline $37.5-45.5$ & $\begin{array}{l}\text { bottom } \\
\text { of run } 4\end{array}$ & not measurable & \multicolumn{4}{|c|}{ A piece of tufa and the rest is chert nodules. } \\
\hline
\end{tabular}




\begin{tabular}{|c|c|c|c|c|c|c|}
\hline Core Box: & 3 & & & & $\begin{array}{l}\text { Number } \\
\text { of Cores: }\end{array}$ & 1 of 3 \\
\hline \multirow[t]{2}{*}{ Location: } & \multirow{2}{*}{\multicolumn{2}{|c|}{ Circle J Farms, AR }} & Lat: & $36^{\circ} 19^{\prime} 27.7^{\prime \prime} \mathrm{N}$ & $\begin{array}{l}\text { Date } \\
\text { Cored: }\end{array}$ & $10 / 10 / 2019$ \\
\hline & & & Long: & $91^{\circ} 29^{\prime} 51.8^{\prime \prime} \mathrm{W}$ & & \\
\hline Core Number: & \multicolumn{2}{|l|}{$\mathrm{CJ} 1$} & & Total Length: & \multicolumn{2}{|l|}{ 110.0" } \\
\hline $\begin{array}{l}\text { Depth Interval: } \\
\text { (in) }\end{array}$ & & Porosity: $\quad(\%)$ & \multicolumn{4}{|c|}{ Description: } \\
\hline $0-1.5$ & & not measurable & \multicolumn{4}{|c|}{$\begin{array}{l}\text { Tufa and some chert nodules, tan to cream in color, not many void } \\
\text { spaces on the surface due to how poorly cemented the sample is, lines } \\
\text { up with next piece. }\end{array}$} \\
\hline $1.5-3.5$ & & not measurable & \multicolumn{4}{|c|}{$\begin{array}{l}\text { A lot of chert and shells that are cemented by the tufa, tan to cream in } \\
\text { color, no real visible void spaces to measure porosity, very poorly } \\
\text { cemented. }\end{array}$} \\
\hline \multicolumn{7}{|l|}{$3.5-5.0$} \\
\hline $5.0-7.0$ & & 37.1 & \multicolumn{4}{|c|}{$\begin{array}{l}\text { All tufa, almost all small voids and one large void, brown to tan to } \\
\text { cream in color, dark brown to red in the large void space, has a void } \\
\text { space at the top that separates the pervious piece, lines up with next } \\
\text { piece, well cemented at top to better/poor cemented. }\end{array}$} \\
\hline $7.0-9.5$ & & 32.9 & \multicolumn{4}{|c|}{$\begin{array}{l}\text { Tufa with small amounts of chert, brown to tan in color, dark brown at } \\
\text { bottom, smaller voids and a larger void near the top, the bottom is cut } \\
\text { off by a larger void space, poor cemented to well cemented at bottom. }\end{array}$} \\
\hline \multicolumn{7}{|l|}{$9.5-10.5$} \\
\hline $10.5-12.0$ & & not measurable & \multicolumn{4}{|c|}{$\begin{array}{l}\text { All tufa, brown to tan in color, smaller voids on one half and other half } \\
\text { is gone due to a large void, well cemented }\end{array}$} \\
\hline \multicolumn{7}{|l|}{$12.0-12.5$} \\
\hline $12.5-13.8$ & & not measurable & \multicolumn{4}{|c|}{$\begin{array}{l}\text { Tufa with some chert, brown to tan in color, smaller voids on one half } \\
\text { and other half is gone due to a large void, well cemented }\end{array}$} \\
\hline \multicolumn{7}{|l|}{$13.8-14.5$} \\
\hline $14.5-17.2$ & & 37.5 & \multicolumn{4}{|c|}{$\begin{array}{l}\text { All tufa, brown to tan in color, dark brown in voids, smaller to larger } \\
\text { voids, has four large voids, well cemented around the large voids and } \\
\text { poorly cemented where smaller voids are. }\end{array}$} \\
\hline \multicolumn{7}{|l|}{$17.2-17.5$} \\
\hline $17.5-18.7$ & & 37.5 & \multicolumn{4}{|c|}{$\begin{array}{l}\text { Tufa with small amounts of chert, brown to tan in color, and some } \\
\text { larger voids, one large one at the bottom, has a large shell at the bottom, } \\
\text { poorly cemented at and better cemented at the very bottom. }\end{array}$} \\
\hline $18.7-25.5$ & $\begin{array}{l}\text { bottom } \\
\text { of run } 1\end{array}$ & & \multicolumn{4}{|c|}{ Drop when coring. } \\
\hline
\end{tabular}




\begin{tabular}{|c|c|c|c|}
\hline $25.5-37.5$ & & not measurable & $\begin{array}{c}\text { A drop when coring along with some broken up pieces of tufa, shells, } \\
\text { and sand mixed together. }\end{array}$ \\
\hline $37.5-48.5$ & & & Drop when coring. \\
\hline $48.5-52.25$ & $\begin{array}{l}\text { bottom } \\
\text { of run } 2\end{array}$ & not measurable & Some broken up pieces of tufa, shells, and sand mixed together. \\
\hline $52.25-64.0$ & $\begin{array}{l}\text { bottom } \\
\text { of run } 3\end{array}$ & & Mostly chert, shells, and sand mixed together. \\
\hline $64.0-110.0$ & $\begin{array}{l}\text { bottom } \\
\text { of run } 4\end{array}$ & & $\begin{array}{l}\text { No recovery and could not drill any further because we ran out of } \\
\text { coring barrels, and then hole collapsed once we pulled out and tried to } \\
\text { get recovery with a catcher, and then could not core the full length } \\
\text { down. }\end{array}$ \\
\hline
\end{tabular}




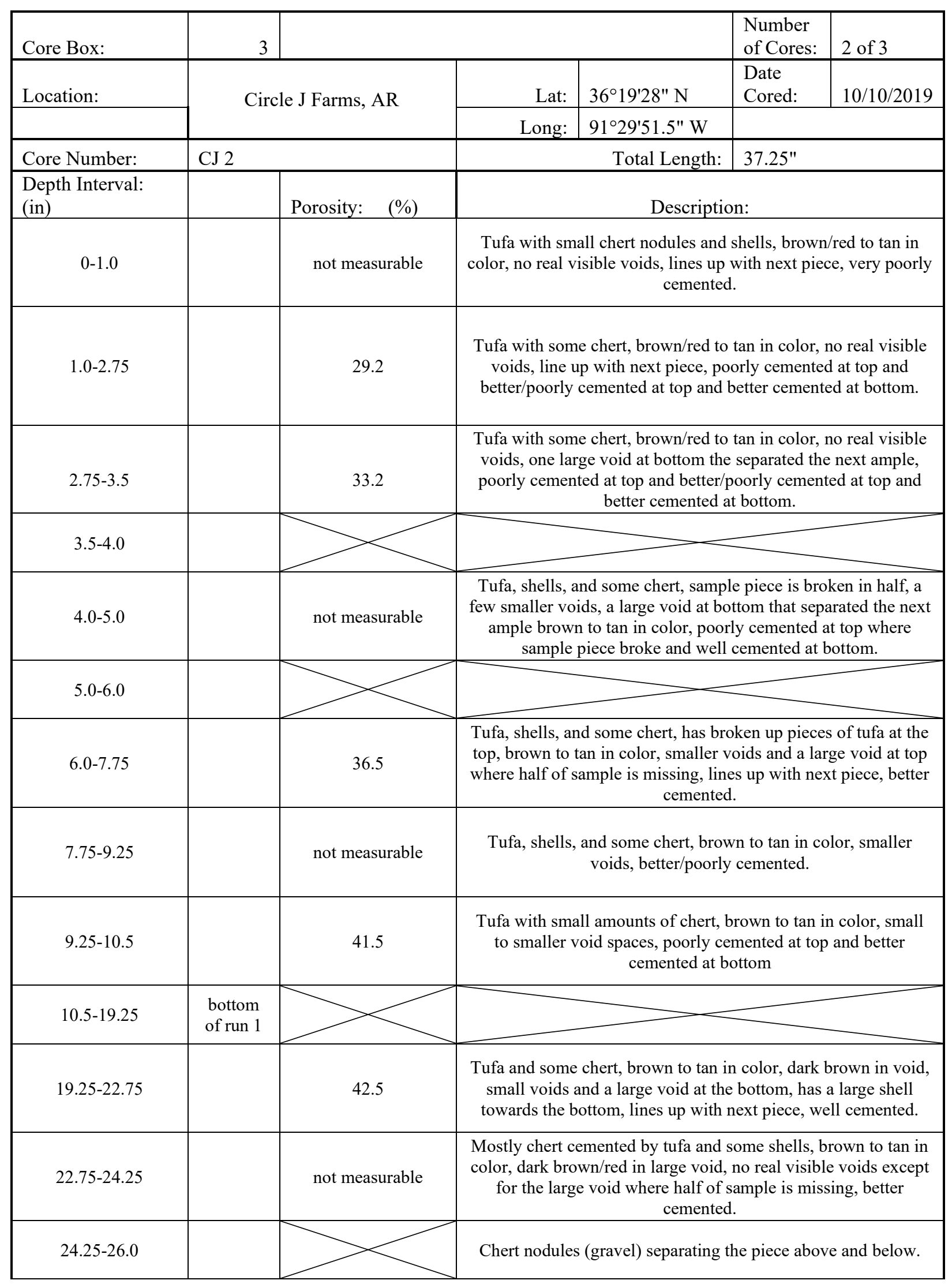




\begin{tabular}{|c|c|c|c|}
\hline $26.0-27.5$ & & $\begin{array}{c}\text { Tufa, shells, and chert nodules, brown to tan in color, very few } \\
\text { voids, very poor/poorly cemented. }\end{array}$ \\
\hline $27.5-37.0$ & $\begin{array}{c}\text { bottom } \\
\text { of run 2 }\end{array}$ & $\begin{array}{c}\text { A drop when coring and no recovery. } \\
\text { bottom } \\
\text { of run 3 }\end{array}$ & $\begin{array}{c}\text { Very little recovery, had broken pieces of tufa, some shells and } \\
\text { one really large shell (1.33" long by 1.5" wide but broken), and } \\
\text { some chert nodules (gravel). }\end{array}$ \\
\hline
\end{tabular}




\begin{tabular}{|c|c|c|c|c|c|c|}
\hline Core Box: & 3 & & & & $\begin{array}{l}\text { Number } \\
\text { of Cores: }\end{array}$ & 3 of 3 \\
\hline \multirow[t]{2}{*}{ Location: } & \multirow{2}{*}{\multicolumn{2}{|c|}{ Circle J Farms, AR }} & Lat: & $36^{\circ} 19^{\prime} 28.0^{\prime \prime} \mathrm{N}$ & $\begin{array}{l}\text { Date } \\
\text { Cored: }\end{array}$ & $10 / 10 / 2019$ \\
\hline & & & Long: & $91^{\circ} 29^{\prime} 49.7^{\prime \prime} \mathrm{W}$ & & \\
\hline Core Number: & \multicolumn{2}{|l|}{ CJ 3} & & Total Length: & \multicolumn{2}{|l|}{ 19.0" } \\
\hline $\begin{array}{l}\text { Depth Interval: } \\
\text { (in) }\end{array}$ & & Porosity: $(\%)$ & \multicolumn{4}{|c|}{ Description: } \\
\hline $0-6.5$ & & 37.6 & \multicolumn{4}{|c|}{$\begin{array}{l}\text { All tufa, brown to tan to cream in color, dark brown in the large } \\
\text { voids, small to larger voids, has four large voids, lines up with } \\
\text { next piece, better cemented at top to well cemented in the middle } \\
\text { to bottom and better cemented at the bottom. }\end{array}$} \\
\hline $6.5-7.75$ & & 35.7 & \multicolumn{4}{|c|}{$\begin{array}{l}\text { All tufa, brown to tan to cream in color, mostly smaller voids, it } \\
\text { has one large void at the bottom that separated the next sample, } \\
\text { better cemented at the top and well cemented at the bottom. }\end{array}$} \\
\hline $7.75-9.25$ & & not measurable & \multicolumn{4}{|c|}{$\begin{array}{l}\text { Tufa with some chert, brown to tan in color, smaller voids, half } \\
\text { of core is missing due to a large void on that side, well } \\
\text { cemented. }\end{array}$} \\
\hline $9.25-10.75$ & & 36.5 & \multicolumn{4}{|c|}{$\begin{array}{l}\text { Tufa, some shells, and chert, brown to tan in color, generally } \\
\text { smaller voids with a large on in the middle, large void at time } \\
\text { that matches up with pervious piece, well to poorly cemented. }\end{array}$} \\
\hline $10.75-12.5$ & $\begin{array}{l}\text { bottom } \\
\text { of run } 1\end{array}$ & not measurable & \multicolumn{4}{|c|}{$\begin{array}{l}\text { Some tufa cement on top of the chert nodules and some on the } \\
\text { bottom, but primarily a chert nodule. }\end{array}$} \\
\hline $12.5-19.0$ & $\begin{array}{l}\text { bottom } \\
\text { of run } 2\end{array}$ & not measurable & \multicolumn{4}{|c|}{$\begin{array}{l}\text { Some tufa cement on top of the largest chert nodules and some } \\
\text { on the bottom, but primarily a chert nodule, other pieces of chert } \\
\text { (gravel), some shells, and some broken up tufa pieces. }\end{array}$} \\
\hline
\end{tabular}


Appendix D. Core box photos

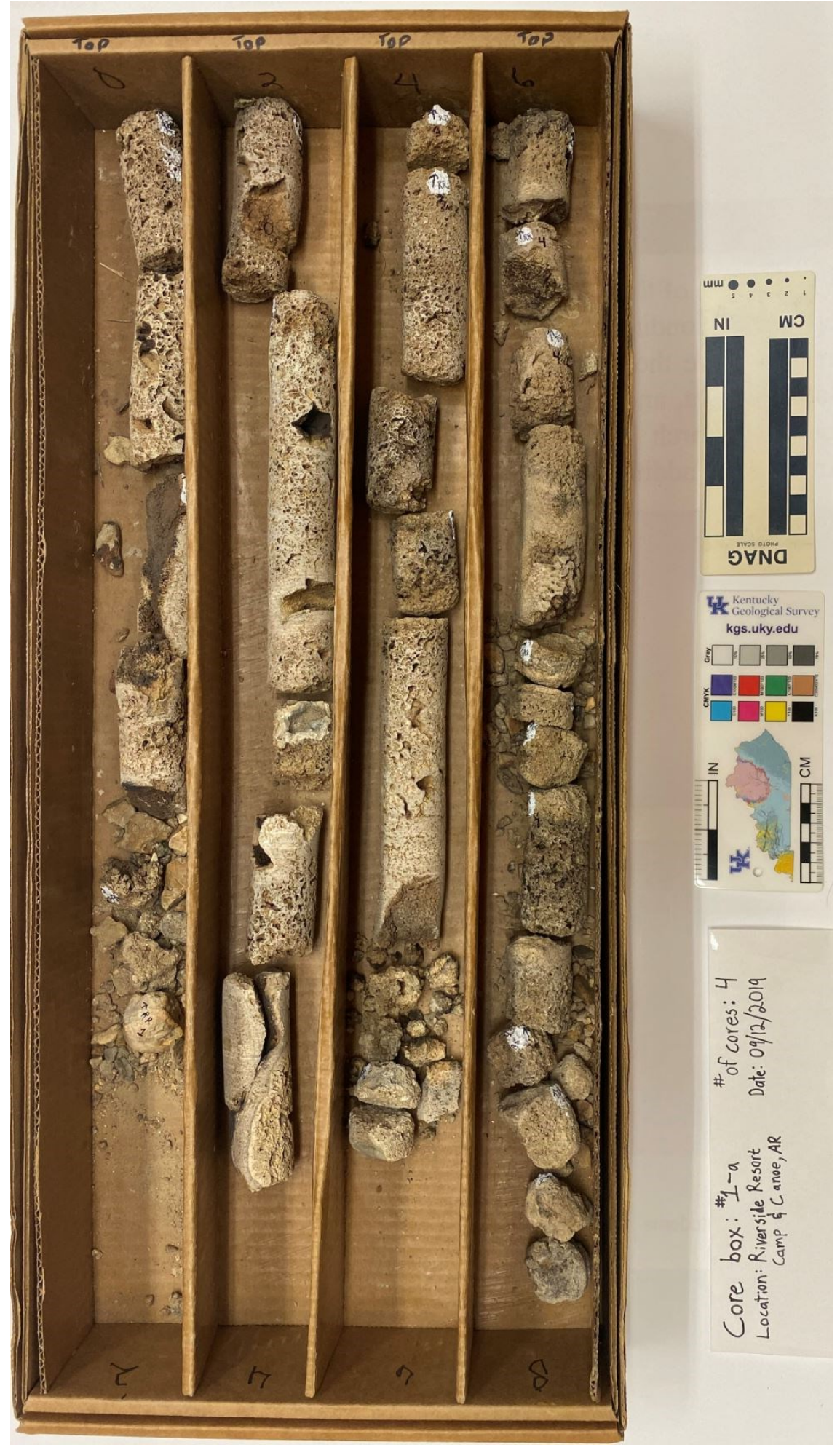

First core box from Riverside Resort Camp and Canoe. 


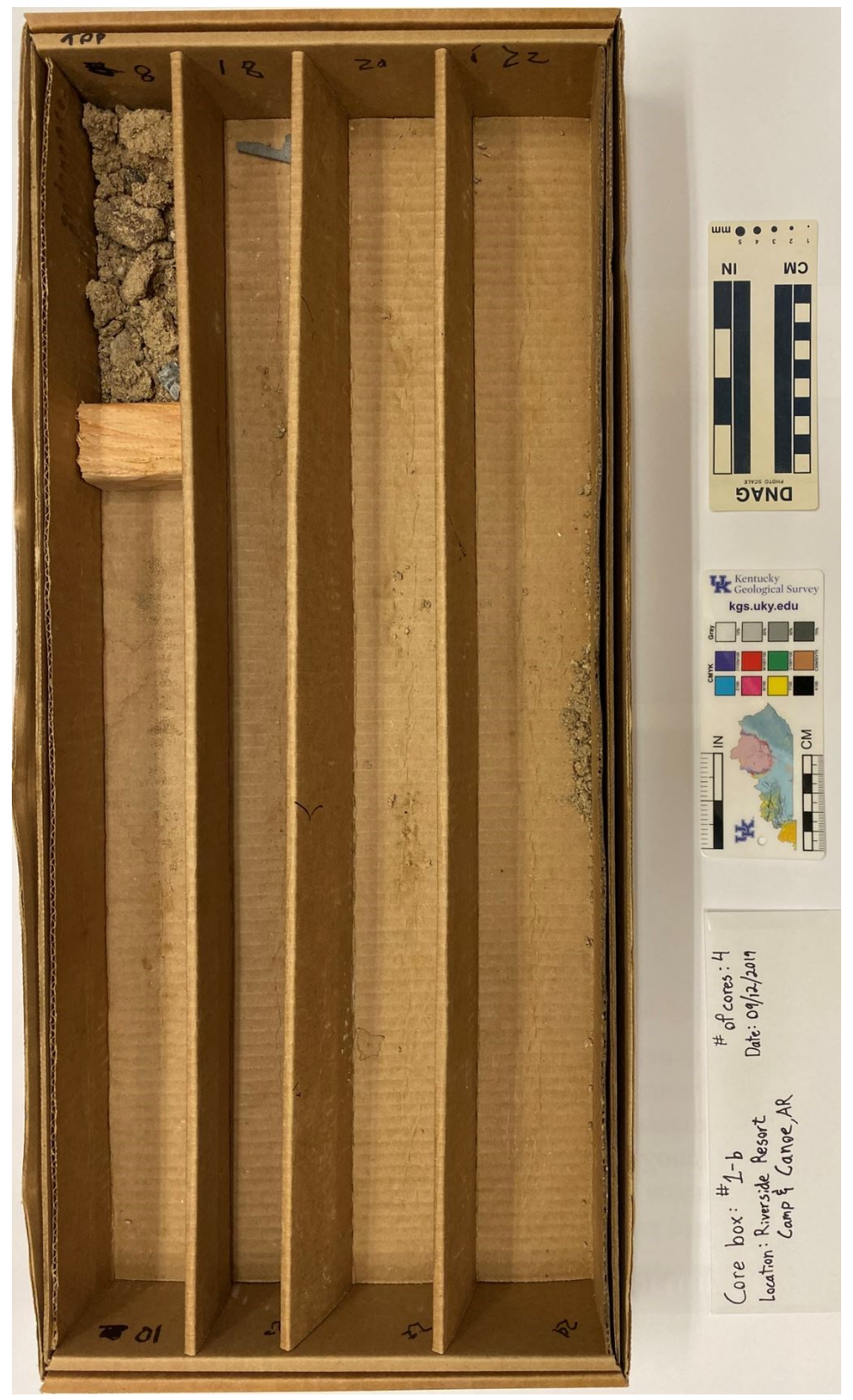

Continuation of the last core in core box from Riverside Resort Camp and Canoe. 


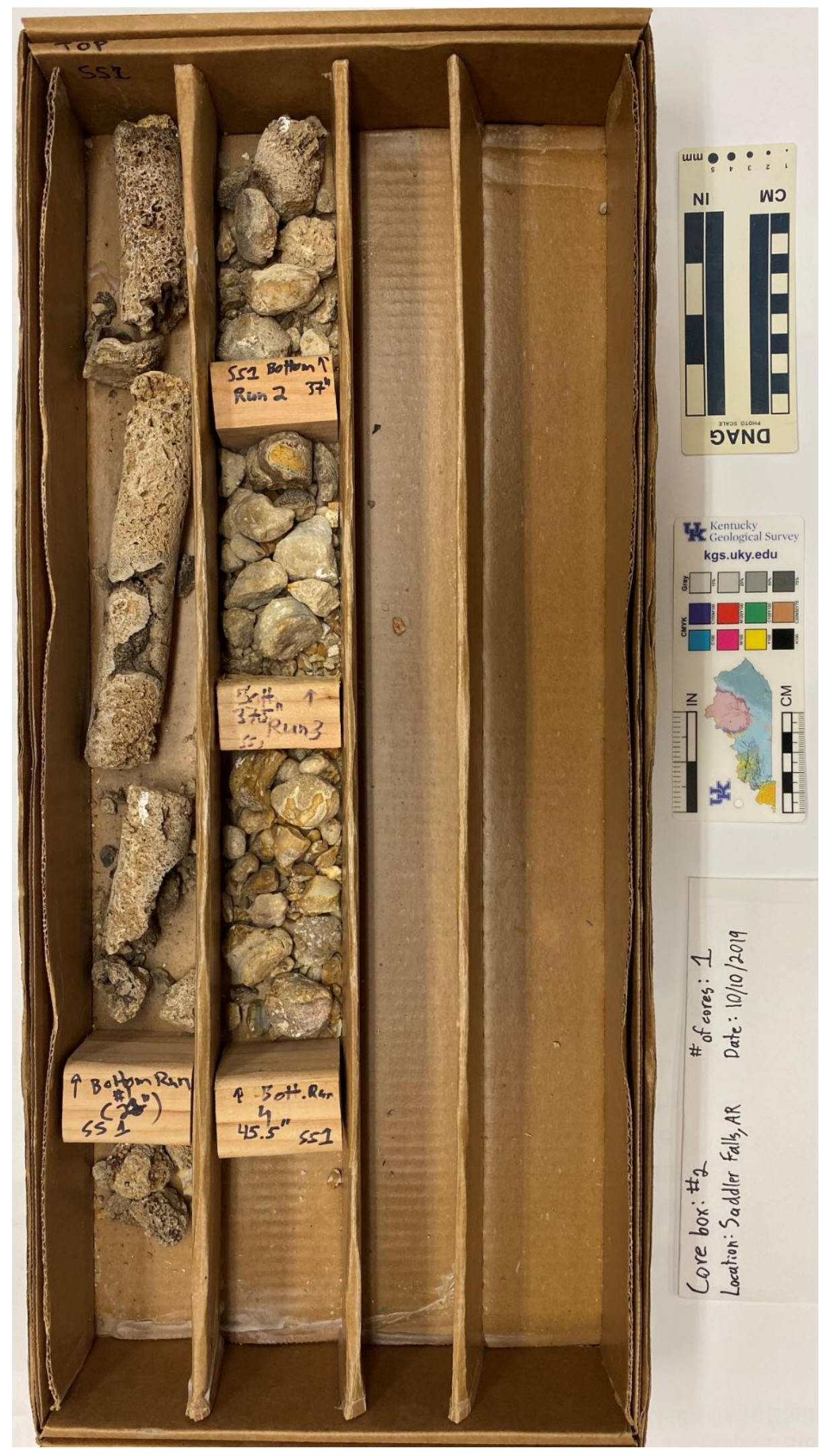

Core box from Saddler Falls. 


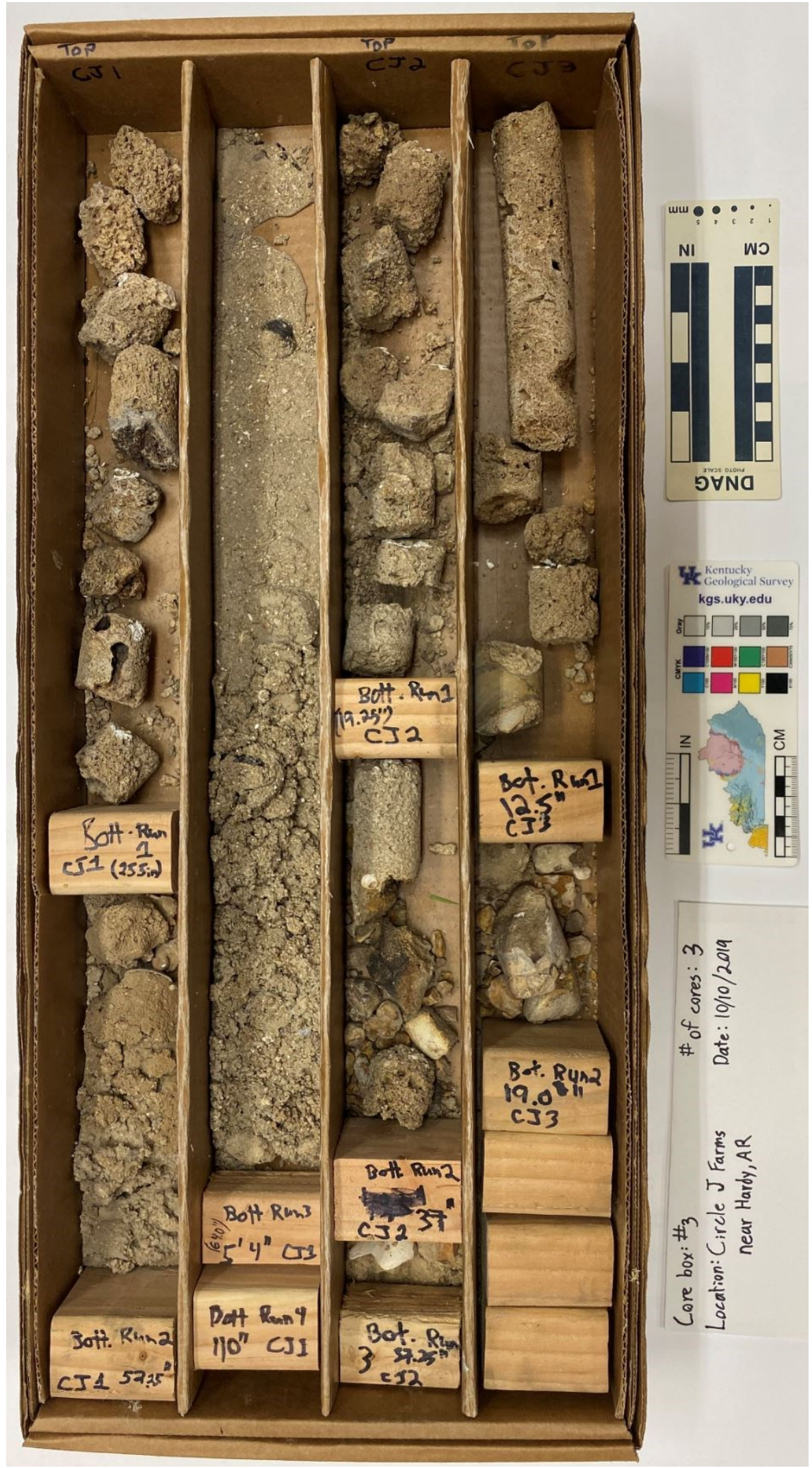

Core box from Circle J Farms. 